\title{
Mild traumatic brain injury : intervention and prognosis
}

Citation for published version (APA):

de Kruijk, J. (2001). Mild traumatic brain injury : intervention and prognosis. [Doctoral Thesis, Maastricht University]. Datawyse / Universitaire Pers Maastricht. https://doi.org/10.26481/dis.20011220jk

Document status and date:

Published: 01/01/2001

DOI:

10.26481/dis.20011220jk

Document Version:

Publisher's PDF, also known as Version of record

\section{Please check the document version of this publication:}

- A submitted manuscript is the version of the article upon submission and before peer-review. There can be important differences between the submitted version and the official published version of record.

People interested in the research are advised to contact the author for the final version of the publication, or visit the DOI to the publisher's website.

- The final author version and the galley proof are versions of the publication after peer review.

- The final published version features the final layout of the paper including the volume, issue and page numbers.

Link to publication

\footnotetext{
General rights rights.

- You may freely distribute the URL identifying the publication in the public portal. please follow below link for the End User Agreement:

www.umlib.nl/taverne-license

Take down policy

If you believe that this document breaches copyright please contact us at:

repository@maastrichtuniversity.nl

providing details and we will investigate your claim.
}

Copyright and moral rights for the publications made accessible in the public portal are retained by the authors and/or other copyright owners and it is a condition of accessing publications that users recognise and abide by the legal requirements associated with these

- Users may download and print one copy of any publication from the public portal for the purpose of private study or research.

- You may not further distribute the material or use it for any profit-making activity or commercial gain

If the publication is distributed under the terms of Article $25 \mathrm{fa}$ of the Dutch Copyright Act, indicated by the "Taverne" license above, 


\section{MILD TRAUMATIC BRAIN INIURY INTERVENTION AND PROGNOSIS}


Universitaite Pers Mastricht

ISBN 9052783322

The publiation of this the is mas finatialty supponted by Ghaxoimithkline, Merck Sharp \& Dohme BV, Jansen Cilag BV, Serono Benelux BV, Buxter BV, Novartis Pharma BV. ASTA Medica BV, Sanof Symolhabo and Schering Nederland BV.

Fomporing on dith

Datawyse | Universitine Pers Mastriclut

Conterillisivitrians

Gerda Deandooven

In: Toon Telleger, Dokter Deter, Amsterdam, Querido, 1997 


\section{MILD TRAUMATIC BRAIN INJURY INTERVENTION AND PROGNOSIS}

\section{Proefschrift}

ter verkrijging van de graad van doctor

aan de Universtiteit Maastricht,

op gezag van de Rector Magnificus,

Prof. dr. A.C. Nieuwenhuijzen Kruseman

volgens het besluit van het Collega van Decanen,

in het openbaar te verdedigen op

donderdag 20 december 2001 om 16.00 uur

door

Jelle de Kruijk

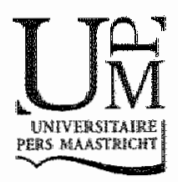


PROMOTOR

Prof. dr. J. Troost

CO-PROMOTOR

Dr. A. Twijnstra

BEOORDELINGSCOMMISSIE

Prof. dr. J.W.L. Stapert (voorzitter)

Mw. Prof. dr. M.P. van Dieijen-Visser

T. Ingebrigtsen MD PhD (Universiteitsziekenhuis Trømsø, Noorwegen)

Prof. dr. Minderhoud (Rijksuniversiteit Groningen)

Prof. dr. M.H. Prins

The research presented in this thesis was performed at the department of Neurology of the University Hospital Maastricht. 
Dokter Deter maakte veel mensen met hersenschuddingen beter. Als ze op zijn stoep lagen te kreunen tilde zijn knecht ze op en droeg ze naar binnen.

Er was een speciale kamer voor hersenschuddingen en hoofdpijn. Dokter Deter had een apparat om hersenschuddingen los te schudden. Dat gebeurde in het donker, in die kamer. De knecht hield het hoofd vast, dokter Deter zette het apparaat aan en even later was de hersenschudding los en schoot naar buiten. In de kelder stond een kast waarin alle oude hersenschuddingen lagen. Het waren er duizenden. Dokter Deter wist niet goed wat hij met ze moest doen. Maar hij vond het ook zonde om ze weg te gooien......

Uit: Toon Tellegen, Dokter Deter, Amsterdam, Querido, 1997 


\section{CONTENTS}

List of abbrevations 8

General introduction 9

CHAPTER 1 Diagnostic criteria and differential diagnosis of mild $\begin{array}{ll}\text { traumatic brain injury } & 17\end{array}$

CHAPTER 2 Incidence of trammatic head or brain injury in the catchment area of the Unversity Hospital Mastricht in 1997

CHAPTER 3 Management of mild tratmatic brain injury lack of consensus in Europe

CHAPTER 4 S-100B and Neuron-Specific Enolase in serum of mild traumatic brain injury patients; a comparison with healthy controls

CHAPTER 5 Olfactory function after mild traumatic brain injury

CHAPTER 6 Prediction of post-traumatic complaints after mild traumatic brain injury early symptoms and biochemical markers

CHAPTER 7 Generic health status following mild tramatic brain injury

CHAPTER 8 Effectiveness of bed rest after mild traumatic brain injury a randomised trial of none versus six days of bed rest 103

CHAPTER 9 Summary and conclusions 121

CHAPTER 10 Samenvatting en conclusies 129

Publications 137

Dankwoord 139

Curriculum vitae 


\section{LIST OF ABBREVIATIONS}

$\begin{array}{ll}\text { EFNS } & \text { European Federation of Neurological Societies } \\ \text { FULL } & \text { 6 days bed rest } \\ \text { GCS } & \text { Glasgow coma scale score } \\ \text { LOC } & \text { Loss of consciousness } \\ \text { MTBI } & \text { Mild traumatic brain injury } \\ \text { NSE } & \text { Neuron Specific Enolase } \\ & \\ \text { NO } & \text { No bed rest } \\ \text { PTA } & \text { Post-traumatic amnesia } \\ \text { PTC } & \text { Post-traumatic complaints } \\ \text { THBI } & \text { Traumatic head and/or brain injury } \\ \text { TIAD } & \text { Traumatically induced axonal damage } \\ \text { VAS } & \text { Visual analogue scale }\end{array}$


ENERAL INTRODUCTION 


$$
\text { s }
$$


Traumatic brain injury is an important cause of morbidity and mortality and is clinically classified as severe, moderate or mild using the admission Glasgow Coma Scale (GCS) score. Precise incidence rates are hard to obtain, but it is clear that most injuries are classified as mild tramatic brain injury (MTBI). Various criteria have been used for the diagnosis and nomenclature. The usual diagnostic criterion for MTBI has been a GCS score of 13 to 15.(1) Names like Commotio Cerebri, Concussion or Mild Head Injury have also been used. On the basis of more recent studies evaluating the association of GCS scores with the presence of intra-cerebral contusions on CT-scans and with long-term outcome, however, it has been suggested to limit MTBI to cases with GCS score of 15 (= optimal) at presentation.(2-4). Duration of post-traumatic amnesia and loss of consciousness at presentation have also been proposed as additional criteria for MTBI $(2,5)$ Outcome after MTBI is mainly determined by the severity of late post-tranmatic complaints (PTC) like headache, dizziness, poor concentration and depression. The severity of PTC declines during the first three months, but their prevalence is still estimated at 20 to $80 \%$ six months after the trauma. $(2,6-8)$ This huge variation probably reflects the different definitions of MTBI and PTC used in these various studies. Most studies have evaluated PTC and/or neuro-psychological test resullts. Although information about impaiment of daily life activities would also be helpful in assessing the consequences of MTBI, onlly a few studies have measured generic health status in MTBI patients. $(9,10)$

Within hours after the trauma, MTBI patients often complain about headache, neck pain, nausea, dizziness and vomiting. Presumably, these early symptoms are caused by the same injury mechanisms as those responsible for late PTC. To date. before 1990 , hardly anything was known about the location and pathophysiology of brain damage after MTBI. Since then, research on animal models and post-mortem studies have revealed trammatically induced axonal damage following MTBI, which was manly located in the frontall and temporal lobes.(11-13) Clinical MRI studies have recently reported signs of brain damage after MTBI, (14-16) while increased concentrations of biochemical markers (S-100B and NSE) suggesting tratmatically induced axonal damage have been found in small groups of MTBI patients. 17,18 )

In addition to radiological and biochemical signs, olfactory dysfunction also seems to be related to traumatic brain damage. (19) Tramata particularly associated with olfactory dysfunction include skull-base fractures and occipital blows 
(with frontal impact) to the head. $(20,21)$ Confirmation of olfactory dysfunction after MTBI would support the hypothesis that a mild trauma can damage structures of the brain somewhere in, or between, olfactory nerve filaments and fronto-temporal cortical structures.

Biochemical markers, olfactory function and acute clinical symptoms could thus be useful parameters to asses the severity of brain damage and presumably improve the prediction of PTC after MTBI. Associations between such acute MTBI parameters and outcome have not been studied so far.

Prevention of PTC is important because they lead to high healthcare costs and loss of labour productivity. $(22,23)$ Measures commonly prescribed following traumatic brain injury are rest and / or taking some time off work, but their effectiveness in preventing PTC has hardly been studied.

The value of bed rest was emphasised in the $19^{\mathrm{t}} \mathrm{century}$ as the primary treatment of many disorders. A recent review of randomised trials on bed rest for several medical conditions (not including traumatic brain injury) concluded that bed rest did not improve the prognosis, and even worsened the outcome in some situations.(24) As far as we know, only one study has evaluated bed rest after MTBI.(25) The author concluded that bed rest of more than two weeks appeared to be related to more PTC. Notwithstanding the lack of evidence for the efficacy of bed rest, almost half of the neurologists in the Netherlands recommend one or more days of full bed rest after MTBI.(26)

Educating patients at the outpatient clinic about PTC within three weeks after MTBI has proved to reduce the severity of these complaints in the long run. (27-29) Since many MTBI patients do not develop PTC at all, reducing needless follow-tip will save money and prevent medicalisation of mainly young and healthy people. Therefore, early recognition of patients not at risk of developing PTC would be useful.

Because of the lack of scientific evidence on the effectiveness of treatment and follow-up of MTB1 patients, no guidelines have so far been agreed upon. The am of present thesis is to provide an impetus to the development of evidence-based management of MTBI patients. 


\section{OUTLINE OF THE STUDY}

The main aim of the present study was to identify ways of predicting and preventing post-traumatic complaints after mild traumatic brain injury. Before we started collecting the data, literature was reviewed about the definition, differential diagnosis, diagnostic tools and treatment of MTBI (chapter 1). Accordingly this overview, we decided upon a useful definition of MTBI and selected relevant outcome parameters for the following studies.

The first two studies estimated the incidence of traumatic head and brain injury in a well-defined catchment area in the Netherlands (chapter 2) and surveyed the management of MTBI patients in several European hospitals (chapter 3). The study reported on in chapter 4 assessed serum concentrations of the biochemical markers Neuron-Specific Enolase (NSE) and S100-B in MTBI patients and in healthy controls. chapter 5 describes the prevalence and severity of olfactory dysfunction after MTBI and correlates olfactory function or dysfunction with biochemical marker concentrations and the presence of acute symptoms. chapter 6 identifies clinical parameters (symptoms and biochemical markers) in MTBI patients at presentation that are predictive of the severity of PTC after six months. In order to develop a clinically useful test to determine which MTBI patients do not require follow-up at the outpatient clinic, we also tried to determine a combination of variables that can predict favourable outcome after six months.

The study reported on in chapter 7 aimed to investigate the generic health status of MTBI patients in the course of six months after the tramma, and searched for associations between the presence of PTC and generic health status after six months.

Finally, in chapter 8 a randomised trial on the effects of six days of bed rest versus no bed rest on the severity of PTC and generic health status after six months was conducted. 


\section{Included patients in different sub-studies}

Oct 1996-June 1999

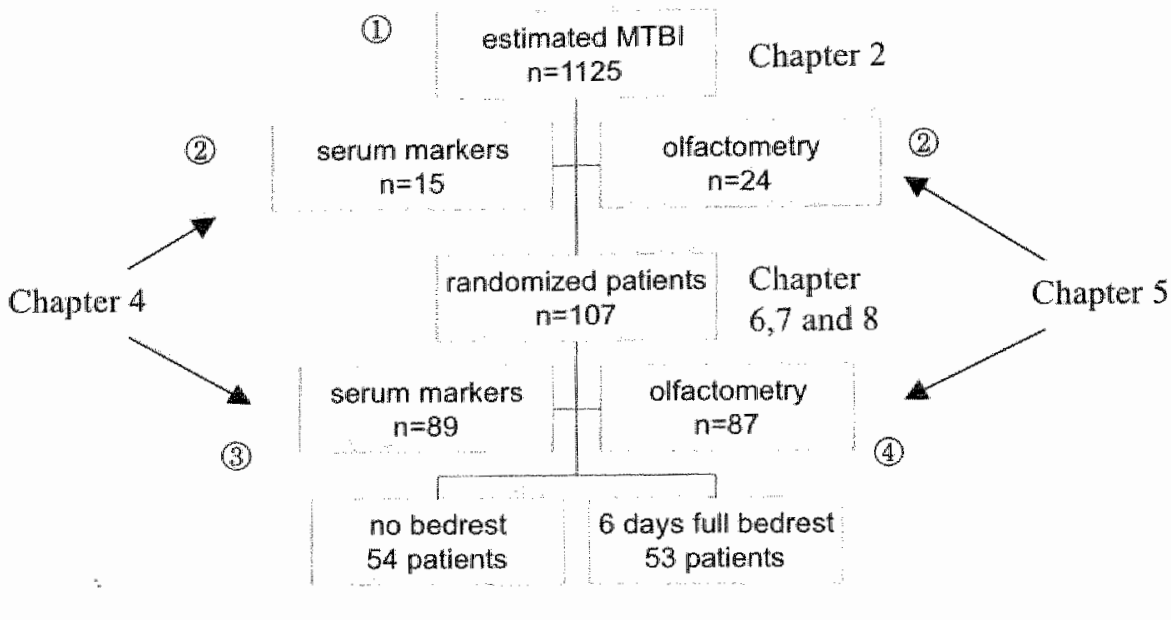

(1) Number of patients is an estimation for the period between Oct 96 and Jun 99, derived from the described MTBI incidence in chapter 2

(2) These patients gave consent for follow-up but did not fullfill the trial criteria because they were shortly observed clinically

(9) Trial-patients who gave consent to taking blood samples

(4) Because of logistic reasons olfactometry was only done by the first 87 patients in the trial 


\section{REFERENCES}

1. Rimel $\mathbb{R}$, Giondan B, Barth J, Jane JA. Moderate brain injury: completing the dinical spectrum of brain trauma. Neurosurgery $1982 ; 11(3): 344-51$

2. Alexander M. Mild traumatic brain injury" Pathophysiology, narural history, and clinical management. Neurology 1995;45:1253-1260.

3. Culorta V, Sementilli M, Gerold K., Warts C. Clinicopathological heterogeneity in the classification of mild head injury. Neurosurgery $1996,38(2): 245-250$.

4. Gomez PA, Lobato RD, Ortega IM, De La Cruz I. Mild head injury: differences in prognosis among patients with a Glasgow Coma Scale score of 13 to 15 and analysis of factors associated with abnormal CT findings. Br J Neurosurg 1996; 10(5):45, $\ldots 60$.

5. Ruef RM, Jurica $P$. In search of a unified definition for mild traumatic brain injury. Brain Iraj $1999 ; 13(12): 943-52$.

6. Naalt van der J, Zomeren A, Sluiter W, Minderhoud J. One year outcone in mild and moderate head injury: the predictive value of acute injury characteristics related to complaints and retum to work. J Neurol Neurosurg Psychiatry 1999;66:207-213.

7. King S. Emotional, neuropsychological, and organic factors: their use in the prediction of persisting postconcussion symptoms after moderate and mild head injuries. $J$ Neurol Neurosurg Psychiatry 1996;61:75-81

8. Rutherford W. Postconcussion synptoms: relationship to acute neurological indices, indiwidual differences, and circumstances of injury. In: Mild Head Injury. New York: Oxford University Press; 1989 . p. 217-240.

9. Panak $\mathrm{C}$, Phillips $\mathbb{K}$, Toller-Lobe $\mathrm{G}$, Durand A, Nagy J. Sensitivity of three recent questionnatres to mild traumatic brail injury-related effects. J Head Trauma Rehabil $1999 ; 14(3): 211-19$.

10. Colantonio A, Dawson D, McLellan B. Head injury in young adults: Jonguterm outcome. Arch Phys Med Rehabil 1998;79:550-8.

11. Povlishock J. Morphopachological change associated with mild head injury. In: Mild head injury. New York: Oxford university press; 1989. 1.37-51.

12. Morehead M, Bartus R, Dean R, Motke J, Murphy S, Sall J, et al. Histopathologic conse quences of moderate concussion in an anmat model: correlations with duration of unconsciousness. Journal of neurotrauma 1994:11(6):657-667.

13. Blumbergs $\mathbb{P}$, Scott $G$, Manavis $\mathbb{J}$, Wainwright $\mathbb{H}$, Simpson $D$, McLaty $A$. Staining of amyloid precursor protein to study axonal damage in mild head injury. The Lancet $1994 ; 344: 1055-1056$.

14. Hadley D, Wilson $L$, Wyper D, Patterson J, Teasdale G, SPECT and MR after focal and diffuse liead injury. Acta neurology, Belgum 1995,95(supp, TC03):109.

15. Naalt wan der J. Joffre $M$, Zomeren van $A$, Sluiter $W$, Minderhoud J. Computed tomography and magnetic resonance imaging in mild to moderate head injury: Early and late imaging related to outcome. Amn Neurol 1999;46(1):70)-77. 
16. Hofman P. Stapere S, wan Kroonenburgh M, Jolles I, de Kruijk J, Wilmink J. MR imaging. single-photon enission $C T$, and neurocognitive performance after mild traumatic brain injury. Am J Neuroradiol 2001;22:441-449.

17. Skogseid I, Nordby H, Urdal P, Paus E, Lilleaas F. Increased serum creatine kinase BB and neuron specific enolase following head injury. Acta Neurochir Wien) 1992;115:106-1 11.

18. Ingebrigtsen T, Romner B, Trumpy I. Management of minor head injury: the value of early computed tomography and serum protein S-100 maesurements. I Clin Neuros $1997: 4(1): 29-33$.

19. Richard L. A review of olfactory dysfunctions in man. Am J Otolaryngol 1979;1(1):57-79.

20. Schechter $\mathbb{P}$, Henkin R. Abnomalities of taste and smell after head trauma. I Neurol Neurosurg Psychiatry 1974:37:802-810.

21. Shiffman S. Mechanjsma of disease. Taste and smell in disease. $N$ Eng J of Med $1983 ; 308(21) \div 1275-78$.

22. Ewans RW. The postconcussion syndrome and the sequelae of mild head injury. Neurol Clin 1992;10(4):815-47.

23. Hase J. Social-economic impact of head injury. Acta Neurochir 1992;55 (suppl):75-79.

24. Allen C, Glasziou P, Del Mar C. Bed rest: a potential harmful treatment needing more careful evaluation. Lancet 1999;354(October 9):1229-1233.

25. "t Hooft van F. Commotio cerebri en andere gevolgen van schedeltraumata; ziekteverloop en prognose. Utrecht: Rijksuniversiteit Utrecht; 1973.

26. Krujik de J, Twijnstra A, Leffers $P$. Geen uniformiteit in radiodiagnostiek en adviezen van Nederlandse neutologen bij patiënten met licht hersenletsel. Ned Tijdschr Geneeskd $1996 ; 140(35): 1763-1765$.

27. Paniak C, Toller Lobe G, Reynolds S, Melnyk A, Nagy J. A randomized trial of two treatments for mild traumatic brain injury: 1 year follow-tup. Brain Inj 2000;14(3):219-26.

28. Wade $D$, King $N$, Wenden $F$, Crawford $S$, Caldwel $F$. Routine follow up after head injury: a second randonised trial. I Neurol Neurosurg Psychiatry 1998;65:177-183.

29. Minderhoud J, Boeleas M, Huizinga J, Saan R. Treatment of minor head irjuries. Clin Neurol Neurosurg $1980 ; 82 ; 127-140$. 


\section{CHAPTER}

\section{DIAGNOSTIC CRITERIA AND \\ DIFFERENTIAL DIAGNOSIS OF \\ MILD TRAUMATIC BRAIN INJURY}

Presented at the III meeting of the European Federation of Neturological Socieries; September 19-25, 1998; Seville

\section{Adapted from:}

Krujik de J, Leffers $\mathrm{P}$ and Twijnstra A.

Dagnostic criteria and differential diagnosis of mild tramanc brain injury. Brain Inj $2001 ; 15(2): 99-107$. 


\section{ABSTRACI}

Brain injury is classified clinically as severe, moderate or mild by injury charactenstics, including admission Glasgow coma score, duration of unconsciousness and post-traumatic amnesia and any focal neurological findings. Most traumatic brain injuries are classified as mild traumatic brain injury (MTBI) Headache, nausea and dizziness are frequent symptons after MTBI and may continue for weeks to months after the trauma. MTBI may also be complicated by intracranial injuries.

Experimental animal nodels and post-mortem studies have shown axonal damage and dysfunction in MTBI. This damage is mostly localised in the frontal lobes. Serum S-100 and NSE have been reported to be markers for the severity of brain damage.

In the literature, indications for radiodiagnostic evaluation following MTBI have been the subject of debate. Radiographs of the skull are used to exclude skall fractures, but are not useful for an evaluation of brain injury. Computed tomography of the brain seems to be the best way to exclude the developthent of relevant intracranial lesions:

MTBI has a good clinical outcome, though a substantial group of patients develop post-traumatic complaints (PTC). There is little information on the effectiveness of various methods suggested for reducing the frequency of
PTC. 


\section{DEFINITION AND CLASSIFICATION OF MILD TRAUMATIC BRA IN INJURY}

Historically, studies on features, frequency and management of traumatic brain injury are difficult to compare because tramatic brain injury and head injury have often been used synonymously. Both are the result of contact or acceleration-deceleration tramma of the head. However, only trammatic brain injury is associated with loss of consciousness (LOC), post-traumatic amnesia (PTA) and/or focal neurological signs. The present overview focuses on mild traumatic brain injury (MTBI).

In the literature, traumatic brain injury is commonly classified as mild, moderate or severe, based on the Glasgow Coma Score (GCS) at first examination.(1) MTBI was initially diagnosed if GCS was $13-15,(2)$ and is also called Commotio Cerebri, Concussion or even Mild Head Injury in some European countries. (3, 4) In view of the extent of neurobehavioural consequences and the possible presence of brain lesions on an acute $C T$, other authors have suggested that trammatic brain injury with GCS 13 or 14 should be classified as moderate.(1, 5-7) This would imply that traumatic brain injury could only be classified as mild if GCS at presentation is 15 . In recent years, duration of PTA and LOC at presentation have been suggested as additional criteria for MTBI (table 1 ).

Table 1. Criteria for mild traumatic brain injury.

\begin{tabular}{|c|c|}
\hline Authors & Criteria \\
\hline Rimel 1982 & $\operatorname{GCS} 13-15$ \\
\hline Williams 1990 & $\begin{array}{l}\text { GCS 13-15 without brain lesion on CT; } \\
\text { Otherwise moderate or severe BI }\end{array}$ \\
\hline Vollmer 1991 & $\begin{array}{l}\text { PTA }<5 \text { min = very mild } \\
\text { PTA }<1 \text { hr }=\text { mild }\end{array}$ \\
\hline Alexander 1995 & $\begin{array}{l}\text { If LOC: sec-min } \\
\text { GCS } 13-15 \text { (probably only } 15 \text { ) } \\
\text { PTA }<24 \text { hours; (mostly minutes to a few hours) } \\
\text { No focal signs } \\
\text { No radiological abnormalities }\end{array}$ \\
\hline $\begin{array}{l}\text { Culotita } 1996 \text { and } \\
\text { Gomez } 1996\end{array}$ & $\begin{array}{l}\text { Segregation of patients with GCS } 15 \text { from those with scores of } 14 \\
\text { and } 13 \text {, based on incidence of necessary surgical interventions }\end{array}$ \\
\hline
\end{tabular}

GCS = Glasgow Coma Scale score.

PTA $=$ Post-traumatic Amnesia . 


\section{DIFFERENTIAL DIAGNOSIS OF MTBI}

Shortly after the trauma, MTBI patients show typical signs and symptoms like headache, neck pain, nausea, dizziness, vomiting and amnesia. It is believed that these signs and symptoms are precipitated by a mixture of brain injury, peripheral vestibular injury and injury to the soft and bony tissues of the head or even neck. Labyrinthal contusion in particular can cause extreme dizziness, vomiting and nystagmus. Acute post-traumatic epilepsy is only reported in about $4 \%$ of MTBI patients.(8)

MTBI can also be accompanied by facial and skull fractures. Facial fractures tend to be extremely painful but do not demand acute surgical intervention. It is estimated that between $3 \%$ and $13 \%$ of MTBI patients have skull fractures. (7-9) The prevalence seems to be dependent on the number of skull radiographs performed in the patient group under investigation. The presence of a skull fracture in MTBI implies an increased risk of intracranial injuries. (8-10)

MTBI can be complicated by intracranial injuries like contusions, subdural, epidural and subarachnoidall haematomas. Estimates of the prevalence of these lesions in MTBI patients range from $5 \%$ to $12 \%$.(11-13) Most intracranial injuries are contusions, which do not demand surgical intervention. Contusions are of prognostic value however, because they are associated with a high incidence of post-traumatic sequelae. Intracranial haematomas, especially epidural haematomas may require surgical treatment.

Within the MTBI group, indicators for a high risk of traumatic intracranial injuries include: GCS $<15$, focal neurological findings, signs of skull base or depressed fracture, early post-traumatic epilepsy, persistent vomiting, progressive headache and 'High velocity' or unknown cause of trauma.(14)

\section{PATHOPHYSIOLOGICAL ASPECTS OF MTBI}

For a long time it was not clear whether MTBI was accompanied by brain damage. Investigations in recent years have revealed information about the location and mechanisms of such brain damage.

EEG power spectra analysis and auditory brain stem-evoked potentials recordings after MTBI suggest that damage to the brain is localised in the cortex and in 
the brain stem. (15) Immunostaining techniques have showm multifocal axonal injury in the formices of the major hippocampal projection pathways.(16) Recently, MRI studies showed cortical lesions in the first month after MTBI. These lesions were predominantly localised in the frontal lobes. (17) Experimental animal models and post-mortem studies have showed traumatically induced axonal damage following brain injury. $(16,18,19)$ Initially, it was believed that tensile forces during the trama immediately tore axons. Povlishock suggested however that the injury is rather the result of impaired axoplasmic transport, axonal swelling and disconnection over a 3 -6 hour period after the injury. This is believed to be the mechanism in tramatic brain injury of all severity's, but the cascade following mild injury differs from that in more severe injury. The endpoint of the cascade in mild injury involves no over axolemmal perturbation, while more severe brain injury results in altered axolemmal permeability. Both, however, ultimately lead to dysunction 12-24 hours after injury. (20)

Biochemical markers confirming axonal damage in MTBL are under investigation. Serum S-100B and Neuron Specific Enolase (NSE) concentrations peak within 6 hours after traumatic brain injury and peak concentrations seem to reflect the severity of the mechanical disruption of brain tissue. (21-25) Recently, elevated S-10OB and NSE concentrations have been reported in patients with MTBI.(21, 26) However, the patient series were small and no comparison was made with a control group without brain injury.

\section{DIAGNOSTICS IN MTBI}

The presence of a skull fracture in MTBI means a 5 times higher risk of intracranial injuries although most patients with intracranial lesions have no skull fracture. (26) Vollmer concluded that information from skull radiographs altered patient management in less than $1 \%$ of tramatic brain injury patients. (27) Several authors have tried to formulate clear indications for performing skull radiographs following head injury, but at this moment no international consensus is available (rable 2.4 ). Recently, most authors have agreed that skull radiographs are not chinically useful because they do not exclude intracraniall lesions. $(9,12,27)$ Never- 
Table 2A. Indication for skull radiographs in patients with traumatic brain injury.

\begin{tabular}{|c|c|c|c|c|}
\hline \multirow[t]{2}{*}{ Authors } & & \multicolumn{3}{|c|}{ Indication } \\
\hline & & PTA & $\mathrm{GCS}$ & other \\
\hline $\begin{array}{l}\text { Masters } 1987 \\
\text { Vollmer } 1991\end{array}$ & $\begin{array}{l}\text { If } \\
\text { If: }\end{array}$ & + & $<15$ & $\begin{array}{l}\text { Clinical Riskfactors } \\
\text { CT indicated }(2 \mathrm{~B}) \\
\text { but not available }\end{array}$ \\
\hline Servadei 1995 & If & + & 14 or 15 & \\
\hline Comez 1996 & If: & + & & \\
\hline Ingebrigtsen 1997 & Never & & & \\
\hline Murshid 1998 & Never & & & \\
\hline
\end{tabular}

"- if one or more criteria present.

${ }^{*}=$ Risk factors: GCS < 15, focal neurological findings signs of skull base or depressed fracture; early post-traumatic epilepsy; persistent vomiting and or progressive headache and High energetic or unknown cause of trauma.

Table $2 \mathrm{~B}$. Indication for CT of the brain im patients with traumatic brain injury.

\begin{tabular}{|c|c|c|c|}
\hline \multirow{2}{*}{ Authors } & \multicolumn{3}{|c|}{ Indication ${ }^{a}$} \\
\hline & PTA & GCS & Other \\
\hline Vollmer $199 \%$ & & $<15$ & $\begin{array}{l}\text { - Focal findings } \\
\text { - Open skull-fracture }\end{array}$ \\
\hline Servadei 1995 & & $<14$ & - fracture on $X$-skull \\
\hline Gomez 1996 & & $<15$ & \\
\hline Ingebrigtsen 1997 & + & & \\
\hline Murshid 1998 & & $<15$ & $\begin{array}{l}\text { - Focal findings } \\
\text { - Depressed fracture } \\
\text { - Persistant headache } \\
\text { or vomiting }\end{array}$ \\
\hline
\end{tabular}

${ }^{\star}=$ if one or more criteria present.

theless, skull radiographs are still frequently performed for brain injury patients in European emergency rooms. (28)

$\mathrm{CT}$ of the bran is conclusive but expensive and not always avalable.

Suggested indications for performing a CT of the brain following head injury are listed in wble $2 B$. Performing an arly CT of the brain in all MTBI patients seems 
to be the best way to exclude the development of intracranial lesions. (12) Small cortical contusions have been found on MRI following MTBI.(17, 29-32) SPECT can show local hyper and hypoperfusion in the same areas.(32-36) The clinical relevance of these two abnormalities is not clear. Abnormalities on MRI and SPECT may be useful for the prognosis in MTBI. (17, 37-40)

To monitor the severity of brain damage, several biological markers are under investigation. NSE and S-100B in serum have been reported to be useful markers for CNS damage after traumatic brain injury. $(12,22,41,42)$ Serum $S-100 B$ in particular seems to be promising as a tool for quantifying brain damage after MTBI.(12)

\section{MANAGEMENT FOLLOWING MTBI}

Over the past years, the annual numbers of patients with traumatic brain injury admitted to hospitals in the US declined from 199 to 98 per 100.000.(43) Adnission following MTBI declined most, from 130 to 51 hospitalisations per 100.000 per year. In 1996, the ratio of patients with mild, moderate and severe traumatic brain injury admitted to the hospital alive was estimated between 8 to 1 to 1.(44) Thuman observed a relative decrease of MTBL hospitalisation rates in the US during the last years. (43) European admission rates for MTBI remain unclear. Clinical observation seems useful in patients with risk factors for traumatic intracranial complications (table $2 A$ ). Difficulties in clinical assessment because of alcohol, drugs or age and lack of a responsible carer are also reasons to admit a patient for observation. It is believed that proper application of such guidelines can further reduce admission rates. $(10,45)$

Patients with MTBI discharged from the emergency department should receive instructions for further management. To detect intracranial complications in the first 24 hours following the injury 'home observation instructions' should be given to a responsible person accompanying the patient. However, compliance with these instructions is probably low $(46-48)$

Recently, the Oxford Head Injury Service developed an intervention protocol for head injury patients in which reduction of anxiety is the most significant element. (49) This protocol was developed on the recognition that emotional factors play an important role in recovery from MTBI. For patients who experi- 
ence post-concussional complaints (PTC), the protocol includes recommendations regarding performance of daily activities, including going back to work. The Oxford Head Injury Service protocol does not include any recommendations to prevent PTC.

Twenty to $80 \%$ of patients with MTBI develop PTC within the first 6 months after the trauma. (50-52) Literature reports on the effect of bed rest and 'taking some time off work' on the development of PTC have been sparse. If there is any effect of bed rest and taking time off work at all, its most effective duration is unknown. Bed rest of more than two weeks following MTBI seems to worsen the outcome after one year. (53) Minderhoud found that a 'strict regime' in MTBI patients, including information about possible complications, reduced the occurrence of PTC. (54) Wade found that routine follow-up after head injury reduced the 'social morbidity' and severity of PTC. (55) Some investigators have also evaluated the effect of specific drugs (CDP-Choline and DGAVP) on PTC. $(56,57)$ No preventive effect could be substantiated.

Presently, no consensus exists among European hospitals regarding the recommendations given to patients with MTBI who are discharged from the emergency room. (28)

\section{CONCLUSIONS}

There have been many studies of MTBI. However, these studies are characterised by lack of uniformity in the diagnostic criteria applied. Future studies in clearly defined MTBI should aim at the elucidation of the effectiveness of various aspects of management in MTBI patients. Results of such studies can be helpful in the process of developing a European consensus. 


\section{REFERENICS}

1. Alexander M. Mild traumatic brain injury: pathophysiology, natural history, and clincal management. Neurology 1995:45:1253-1260.

2. Rimel R, Giordani B, Barth J Jane JA. Moderate brain injury: conpleting the clinical spectrum of brain tramma. Neurosurgery 1982;11(3):344-51.

3. Naalt van der J, Zomeren van A, Minderhoud J. Schedel-en hersenletsel bij volwassenen. Ned Tijdschr Geneesk 1994:138(46):2279-83.

4. Krujik de J. Diagnoscic criteria and differential diagnosis of mild tramaric brain injury. Brain Inj 2001;15(2):99-107.

5. Williams D, Levin H, Eisenberg H. Mild head injury chassification. Neurosurgery $1990: 27(3): 422-428$

6. Culotta V, Sementili M, Gerold K, Wats. C. Chicopathological heterogencity in the dassification of inild head injury. Neurosurgery 1996;38(2):245-250.

7. Gomez $\mathbb{P A}$, Lobato $\mathbb{R D}$, Orega JM, De La Craz J. Mild hend injury: differences in prognosis among patients with a Glasgow Coma Sale score of 13 to 15 and analysis of factors associated with abnomal CT findings. Br I Neurosurg 1996;10(5):453-60.

8. Murshid W. Management of minor head injuries adnission criteria, radiological evaluation and treament of complications. Acta Neurochir 1998;140:56-64.

9. Servade F, Ciucci G, Loroni $\mathbb{L}$, Cuscini M, Piola C, A rista A. Dingnosis and mangemente of minor head injury: a regional multicenter approach in Italy. I Tramm Inj Infect Crit Care $1995 ; 39(4): 696-701$

10. Mendelow A, Campbell D, Jeffrey R, Miller J, Hessett C, Bryden I, et al. Admission after mild head injury: benefits and costs. BMJ 1982;285:1530-1532.

11. Holmes JF, Bater ME, Derlet RW. Falure of the Miller criteria to predict significant intracranial injury in patients with a Glasgow Coma Scale score of 14 after minor head trama. Acad Emerg Med 1997;4(8):788-92.

12. Ingebrigtsen $T$, Romner $B$. Trumpy J. Management of minor head injury: the value of carly computed tomography and sem protein S-100 maesurements. I Chin Neurosc $1997: 4,(1): 29-33$.

13. Miller EC, Holmes JF, Derter RW. Utilizing clinicall factors to reduce head CT scan ordering for numor head trama patients. I Emerg Med 1997;15(4):453-7.

1.4. Masters SJ, McClean PM, Arcarese JS, Brown RF, Campbell JA, Freed HA, at al. Skull $x$-ray examinations after head tramma Recommendations by a multidisciplinary panel and validation study. N Engl J Med 1987:316(2):84-91.

15. Montgomery E, Fenton G. McClelland R, MacFlynn G, Rutherford W. The psychobiology of minor head injury. Psychological medicine 1991;21:375-384.

16. Blumbergs $P$, Scotr $G$. Manavis J, Wainwriglit H, Simpson D, McLean A. Staning of anylow precursor protein to study axonal damage in mild head injury. Lancer 1994:344:1055-1056. 
17. Naalt van dex J, Joffe M. Zomeren van A, Sluiter W, Minderhoud J. Compured tomography and Magnetic Resonance Imaging in mild to moderate head injury: Early and late imaging related to outcome. Ann Neurol 1999;46(1):70-77.

18. Povlishock J. Morphopathological Change Associated with mild head injury. In: Mild head injury. New York: Oxford university press; 1989. p. 37-51.

19. Morehead M, Bartus R, Dean R, Miotke J, Murphy S, Sall J, at al. Histopathologic consequences of moderate concussion in an animal model correlations with duration of unconsciousness. I Neunotramma 1994,11(6):657-667.

20. Povlishock JT, Jenkins LW. Are the pathobiological changes evoked by tramatic brain injury inmediate and irreversble? Brain Pathol 1995;5(4):415-26.

21. Skogseid 1, Nordby $H$, Urdal P, Pats E, Lilleas F. Increased serum Creatine Kinase BB and Neuron Specific Enolase following head injury. Acta Neurochir (Wien) 1992;115:106-111.

22. Woergen $C$, Rothoen D. Holzchuh M, Metz $C$, Brawanski A. Compatison of serial S-100 and NSE serum maesumants after severe head injury. Acta Nenrochir $1997: 139: 1161-1165$.

23. Rabe A, Groms C, Keller M, Dohnert J, Sorge O, Seifert V. Correlation of computed tomography findings and serum bran damage markers following severe head injury. Acta Neurochurg (Wien) 1998;140(8):787-91.

24. Rarbe A, Menon D, Gupta S, Czosnyka M, Pickard J. Jugular venous and arterial concentrations of serum $S-100 \mathrm{~B}$ protein in patients with severe head injury: apilor study. I Neurol Neurosurg Psychiatry 1998;65:930-932.

25. Rothoerl R, Woertgen C, Holzhusch M, Metz C, Brawanski A. S-100 serum levels after minor and major head injury. I Trama 1998;45(4):765-7.

26. Ingebrigtsen $\mathbb{T}$, Romner 13 . Management of minor head injuries in hospitals in Norway. Acta Neurol Scand 1997,95:51-55.

27. Vollmer $D$, Dacey $R$. The Maragenent of mild and moderate head injuries. Neurosurgery Clinies of North America 1991;2(2):437-455.

28. Krajk de J., P. Leffers and A. Twijnstra. Management of mild tramatic brain injury: lack of consensus in Europe. Ban inj $2001,15(2): 117-124$

29. Bisenberg $H$, Levin $H$. Computed Tomography and magnetic Resonance inaging in mald to moderate head injury. In: Mild head injury. New York: Oxford university pres; 1989 . p. $133-144$

30. Rrugrer J, Vogt J. Stappenbeck C. Sohoof C. Pressler M. EEG, CCT and MRT bei putchten nach teichtem and mittelschwerem schade-him-tranma. Eine untersuchung be 102 patienten. Nervenare 1991;62:226-231.

31. Newon M. Greenwood R, Brition K, Chadesworla M, Nimmon C, Carroll M, et all A study conparing SPECT with CT and MRI after closed head injury. J Neurol Newrosurg
Psychiary $1992,55 \cdot 92,94$.

32. Hadley D, Wilson L. Wyper D, Patrerson J, Teasolale G. SDECT and MR after focal and difuse hend injury. Acta Neurology, Belgum 1995,95(supp, TC03):109.

33. Nedd K, Sakianakis $G$. Ganz $W$, Urichio $B$, Vemberg D, Villanuewa $P$, et al. 99 TC-HMPAO SPECT of the bain in wild to moderate tramatic brain injury patents: contumed with $\mathrm{CT}-\mathrm{a}$ prospective study. Bran Inj $1993 ; 7(6): 469-479$. 
34. Ichise $\mathbb{M}_{\text {: }}$ Chung $D$, Wang $P$, Worzman $G$, Gray $B_{n}$ Franks $W$. Techneticum-99m-HMPAO SPECT, CT and MRI in the evaluation of patients with chronic tramatic brain injury: A correlation with neuropsychological performance. J Nucl MED 1994;35:217-226.

35. Jacobs $A$, Put $\mathbb{E}$, Ingels $M$, Bossuyt A. Prospective evaluation of Tc-99m-HMPAO SPECT at the early stage and during one year follow-up of mild injury. I Nucl Medt $1995 ; 35(6): 942-947$.

36. Sakas E, Bullock R, Patterson J, Hadley D, Wyper D, Teasdale G. Focal cerebral hyperenaia after focal head injury in humans: a benign phenonenon. J Neurosurg 1995;83:277-284.

37. Kay $T$, Newman B. Fazzin E. Evidence for brain damage in post-concussion syndrone. Neurology 1992;42(suppl 3):411.

38. Masdeu J, Van Heertum R, Kleiman A, Anselmi $G$, Kissane K, Horng J, et al. Early Single Photon Emission Computed Tomography in Mild Head Trauma a controlled study. J Neuroimag 1994;4(4):177-181.

39. Jan MM, Camfield PR, Gordon K, Camfield CS. Vomiting after mild head injury is related to migraine. J Pediatr $1997 ; 130(1): 134-7$.

40. Cicerone K, Smith L, Ellmo W, Mangel H, Nelson. P, Chase R, et al. Neuropsychological rehabilitation of mild traumatic brain injury. Brain Injury 1996;10(4):277-286.

41. Persson $\mathbb{L}$, Hardemark H, Gustafsson J, Rundstrom $G$, Mendel-Hartvig I, Esscher $T_{\text {, }}$ et al. S-100 Protein and Neuron-Specific Enolase in cerebrospinal flud and serum: markers of cell danage in central nervous systen. Stroke 1986;18(5):9!1-118.

42. Yamazaki $Y$, Yada $K$, Morri $S$, Kithahara $T$, Ohwada $T$. Diagnostic Significance of serum Neuron-Specific Enolase and Myelin Basic Protein assay in patients with acute head injury. Surg Neurol 1995;43:267-271.

43. Thuman $D$, Guerrero $M$. Trends in hospitalization associated with tramatic bran injury. JAMA $1999 ; 282(10): 954-57$

44. Kraus J, McArthur D, Silwerman T, Jayaraman M. Epidemiology of brain injury. In: Nanyan R, Wilberger J, Powlishock J, editors. Neutomauma. New York: Mc Graw-Hill; 1996. p. 13-30.

45. Miller J, Jones P, Dearden $N$, Tocher J. Progress in the management of head injury. British Journal of Surgery 1992;79:60-64.

46. Saunders CE, Cota R, Barton CA. Rellability of home observation for victins of mild closed-head injury. Ann Emerg Med 1986;15(2):160-3.

47. Warren D, Kissoon N. Usefulness of head injury instruction forms in home obserwation of mild head injuries. Pediatr Emerg Care 1989,5(2):83-5.

48. Louw de $A$, Twijnstra $A$, Leffers $A$. Weinig unifomiteit en slechte therapietrouw bij het wekadvies na tramma capitis. Ned Tijdschr Geneesk 1994;138(44):2197-2199.

49. King $N$, Crawford $S$, Wenden $F$, Moss $N$, Wade $D$. Interventions and service need following mild and moderate head injury: the Oxford Head Injury Serwice. Clin Rethat $1997 ; 11: 13-27$.

50. Rutherford $W$. Postconcussion symptoms: relationship to acute newrological indices, individual differences, and circumstances of injury. In: Mild Head Injury. New York: Oxford Universicy Press; 1989 . p. 217-240. 
51. Bohmen $N$, Winten $G$, Twingtra $A$ wan Zutphen W, Jolles $J$. The constellation of late post-traumatic symptoms of mild head injury patients. I Neurol Rehab 1995,9(1):33-39.

52. Naal van der J. Zomeren A, Sluiter W, Minderhoud J. One year outcome in mild and moderate head injury: the predictive value of acute injury characteristics related to complaints and return to work. I Neurol Neurosurg Psychiatry 1999;66:207-213.

53. 'Hooft van E. Conmotio cerebri en andere gevolgen var schedeltramata; ziekteverloop en prognose. Utrecht: Rijksuniversiteit Utrecht: 1973.

54. Minderhoud J, Boelens M. Huizinga J, Saan R. Treatment of minor head injurtes. Clin Neurol Neurosurg 1980;82:127-140.

55. Wade D, King $N$, Wenden F, Crawford S, Caldwel F. Routine follow up after head injury a second randomised trial. J Neurol Neurosurg Psychatry 1998;65:177-183.

56. Levin H. Treatment of postconcussonal symptoms with COP-choline. I Neurological Sci $1991 ; 103($ suppo $) \times 39-542$.

57. Bohnen N1, Twijnstra A, Jolles $f$. A controlled trial with vasopressin analogue (DGAVP) on cognitive recovery immediately after head trama. Neurology $1993,43(1): 103-6$ 


\section{8 \\ CHAPTER}

\section{INCIDENCE OF TRAUMATIC HEAD OR BRAIN INJURY IN THE CATCHMENT AREA OF THE UNIVERSITY HOSPITAL MAASTRICHT IN 1997}




\section{ABSTRACT}

Introduction: Reliable epidemiological figures about tratmatic head and brain injury (THBI) are hard to obtain. This is partly due to the fact that many specialties are involved in THBI care, and partly to the variations between hospitals in the frequency and spectrum of severity of head injury. A frequently used method for calculating the incidence rate of THBI is counting admissions. This could, however, lead to inaccurate estimates because the catchment area is usually not precisely known. The objective of the present study was to measure the incidence of THBI in a well-defined catchment area.

Methods: At the University Hospital of Maastricht (azM), we collected data on head-injury patients who wisited the emergency room in 1997. The database was further completed by adding case reports of patients found in hospital records (ICD codes) and records of the Radiology department. The $a z M$ is the only hospital in the city of Maastricht and its surrounding area and has an adherent population of approximately 231,000 people.

Reswlts: The emergency room was attended by 1933 THBI patients in 1997. Head trauma without loss of consciousness (LOC) and / or amnesia was diagnosed in $75 \%$ (1440) of cases. Mild traumatic brain injury (MTBI) was diagnosed in $24 \%$ (467) of all THBI patients. MTBI was diagnosed in $95 \%$ of patients with brain injury; de rest was diagnosed as moderate or severe traumatic brain injury ( 26 patients; $1 \%$ of all THBI). The mean age was 30 years (range $0-97$ ) and one-third (29\%) of the patients were below the age of 15 . Two-thirds $(67 \%)$ of the patients were male. An X-ray of the skull was made in $15 \%$ of the cases. Relevant abnormalities were found in $8 \%$ of these $X$-rays. Eleven percent of the patients were admitted for observation. The incidence rate of THBI in 1997 was $836 / 100,000$ and the incidence of admission $88 / 100,000$. The incidence of MTBI was 202/100,000. The causes of THBI were falls $(43 \%)$, traffic accidents $(22 \%)$, violence $(15 \%)$, sports injuries $(7 \%)$ and accidents at work $(4 \%)$. 
Conclusion: The proportion of THBI patients with mild injuries $(99 \%$, only head injury plus mild THBI) was high compared to that in other studies. The frequency of hospital admissions was extremely low. The fact that this study was conducted in a well-defined catchment area supports the credibility of the data. There were, however, two sources of bias, with opposite effects on the incidence estimate. Problems of identifying patients by case records may have led to underestimation, while inclusion of patients from outside the catchment area may have led to overestimation. Although the precise impact of the resulting bias is unknown, it is believed that the incidence figures from the present study are more reliable than previously published data.

\section{INTRODUCTION}

In Western countries, traumatic injury is an important cause of morbidity and mortality. It is in fact the most important cause of death below the age of 45 years. (1) One-third of admissions for traumatic injury concerns head and brain injury.(2) Traumatic head and brain injury (THBI) especially affects men between the ages of 15 and 30.(3) These injuries not only lead to high costs of health care, but also to loss of productivity. (4-7)

More information on the burden imposed by these injuries on the health care system and the social and economic consequences can only be obtained from epidemiological data on THBI. Although several research projects reported in the medical literature have described the frequency of this injury, they have used different names, definitions and registration policies, making it difficult to compare THBI frequencies in a specific area with those in other countries or regions. One of the reasons is the involvement of several specialties in the care of these patients. In addition, there is a group of patients who are seen only by the general practitioner or do not seek any medical assistance at all. (6) Callculating the incidence and admission rates for a country as a whole is tifficult because catchment areas are difficult to define. In the southern part of the Dutch province of Limburg, the situation is quite unique in that the specific catchment areas of the various hospitals can be accurately defined. The purpose of the present study was 
to assess the incidcnce of THB in the catchment area of the University Hospital of Mastricht (azM), measured as the numbers of patients seen in the emergency room.

\section{METHODS}

All patients with "THBI seen in the emergency room of the azM between January 1 st and December 31 st, 1997 were included in the research population. Patients who were fust seen in the emergency room of another hospital and were subsequently referred to the azM because of its regional tratuma center function were excluded.

THBI was defined as the presence of clinical signs of injury to the head or brain. A distinction was made between patients with and those without brain injury. The severity of traumatic bram injury was classified by means of the "Glasgow Coma Scale" score (GCS; Table 1), which is used to quantify the level of consciousness of trauma patients. This is done by assessing (a) active opening of the eyes ( $E$ score), (b) best motor response ( $M$ score) and (c) best verbal response (V score). Summation of the scores on these aspects results in the EMV score, ranging from 3 (minimum / worst score) to 15 (maximum / best scome).

The catchment area of the a M inchudes about 231,000 people. Pacients were first seen by an emergency room physician, after which a neurologist was consulted in the case of head injuries with clinical signs of brain injury.

Patients with a minor bran injury were usually discharged with a printed waking advice arrer having been exwned at the azM Energency Room. For the purpose of the present study, we assumed that patients with minor injuries would have retumed if they had suffered any complications. Admitance of patients with minor brain injury was indicated when risk factors like skull fracture, persistent amnesia or problems implementing the waking advice for example singlemperson houschold) wete present. Patients with moderate and severe brain injuries were as a rule admitred for observation.

To find out how many patients with a THBI were seen in the emergency room, a survey was made by means of a purpose-designed registration fom, which was filled out for every patient sen in the department, combined with a chart review. Becatuse visits to the chergency room are not registered as admitance or 
Table 1. Definitions of severity of traumatic head and brain injury.

\begin{tabular}{ll}
\hline Severity & Criteria \\
\hline Trauma Capitis without brain injury & GCS score 15, no PTA, no LOC \\
Mild traumatic brain injury & GCS score 13-15 (if 15: at least PTA or LOC) \\
Moderate tratumatic brain injury & GCS score 9-12 \\
Severe traumatic brain injury & GCS score 3-8
\end{tabular}

GCS= Glasgow Coma Scale.

PTA $=$ Post Traumatic Amnesia.

LOC = Loss of Consciousness.

discharge, these patients were not coded on the basis of the "International Classification of Diseases' (ICD), while admitted patients were registered by the Hospital's Registration Office and classified by ICD codes $(800,801,803,804$, 850-854). Missing data from these patients was added from chart reviews. The data file was further supplemented by comparisons with the requests for radiological evaluation made during the research period, which we received from the Radiology Department. This resulted in the addition of some patients who thad been missed. To get an impression of the number of patients belonging to other catchment areas, an a-selective sample of 100 patients was taken to verify their place of tesidence.

\section{RESULTS}

During the period of data collection, 26,464 patients were seen at the emergency room of the azM. Of these, $1933(7 \%)$ had a THBI. The files of the Radiology Department revealed an additional 31 requests for post-traumatic skull $X_{-}$-rays for patients not yet included in the registration (i.e., head injury had not been entered on the original emergency room form). We concluded that these patients had suffered a traumatic head injury without brain injury since no neurologist had been consulted in any of these cases.

The average age of the group as a whole was 30 years (range: 0.97 years); 557 patients (29\%) were below the age of 15 . The group included 1297 men $(67 \%)$ and 636 women $(33 \%)$ (fig 1). The incidence of THBI was $837 / 100,000$ inhabit- 

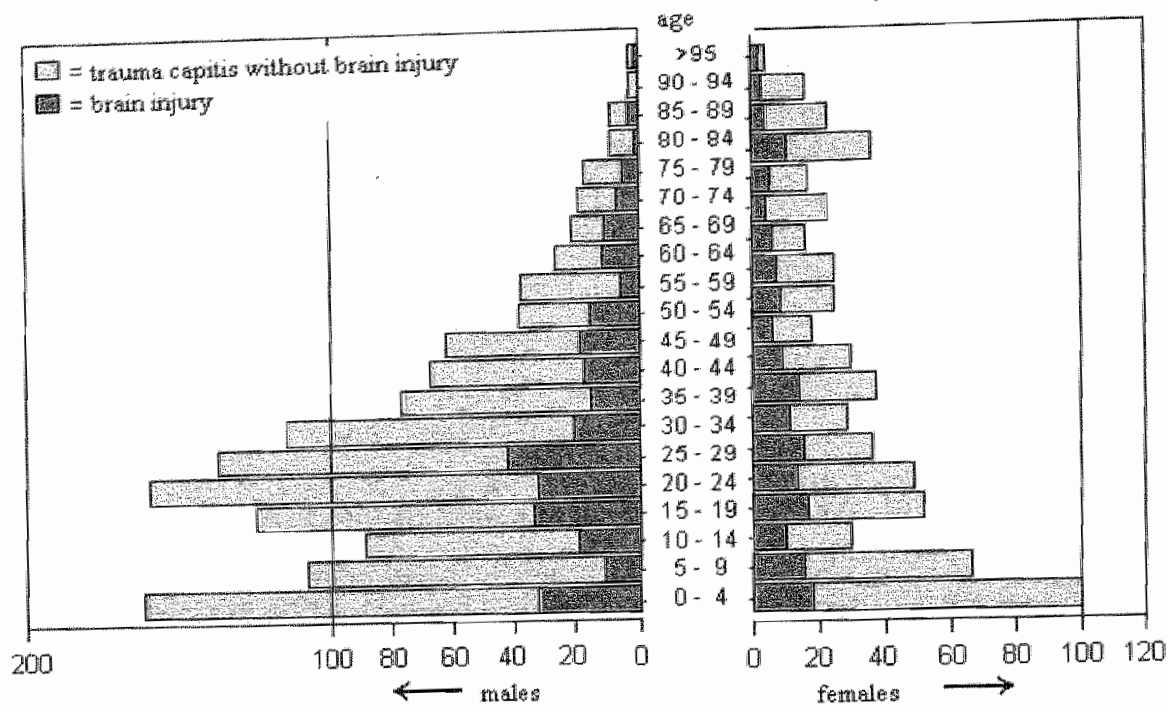

Fig 1 . Number of patients with traumatic head and brain injury presenting at the emergency room of the University Hospital Maastricht in 1997.

ants. Of the 1933 patients, 1440 (74\%) had no brain injury (trauma capitis), while 493 did have a brain injury. Traumatic brain injury was further subdivided into mild in 467 patients (95\%), moderate in 7 (1\%) and severe in $19(4 \%)$. An X-ray of the skull was made in 284 cases (15\%); fractures (or strongly suspected fractures) were seen in 21 patients (7\%).

Catses of the head or brain injury (Table 2) included falls ( $43 \%$ of cases), traffic accidents $(22 \%)$, assaults $(15 \%)$, sports $(7 \%)$ and accidents at work (4\%). The remainder of the patients $(9 \%$ ) had other causes (for example collapse) or the callse could not be retrieved.

Of the total of 1933 patients, $204(11 \%$ were admitted to the hospital (table 2). The incidence of admittance was thus $88 / 100,000$ inhabitants. Seven patients with a severe tratumatic head or brain injury died in the hospital (of whom one in the emergency room): two of these patients had a subdural haematoma, one an epidural hacmatoma, one elevated intracranial pressure and one diffuse brain injury; two had been shot through the skull. Two patients with a subdural 
Table 2. Causes and admission rate of traumatic head and brain injury.

\begin{tabular}{|c|c|c|c|c|c|c|c|c|c|}
\hline \multirow[t]{2}{*}{ Severity } & & \multirow[t]{2}{*}{ r } & \multicolumn{6}{|l|}{ Cause } & \multirow[t]{2}{*}{ Admission } \\
\hline & & & rall & Traffic & Work & Sports & Assault & Other in & \\
\hline & TC & $144075 \%$ & $690(47 \%$ & $209(16 \%$ & $64(4 \%)$ & $102\left(77_{1+1}^{\mathrm{ag}}\right.$ & $230(16 \%)$ & $145\left(10^{\circ}\right)$ & $232 \%$ \\
\hline Mild & $\mathrm{TE}$ & $467\{24 \%$ & $142(30 \%)$ & $203(4.3 \%$ & $150 \%$ & $26\{6 \%$ & $49(11 \%$ & $32: 7 / a\}$ & $15 \%\{34 \%$ \\
\hline Moderate & $T \mathrm{TH}$ & 7 & $3(43 \%)$ & $3(43 \%)$ & - & - & $1(14 \%)$ & - & $6(86 \%)$ \\
\hline Sentere & $\mathrm{TB}$ & 19 & $3(16 \%)$ & $10(52 \%$ & & - & $2(11 \%$ & $4(21 \%)$ & $18(95 \%)$ \\
\hline Total & & $1933100 \%$ & $238(43 \%)$ & $425\{22 \%$ & $79[4 \%$ & $1280 \%$ & $282015 \%$ & $18109 \%$ & $204\left(111^{\circ}\right)$ \\
\hline
\end{tabular}

$\mathrm{TC}=$ trauma capitis (head injury without bram in iñury)

$T B=$ tratumatic brain injury.

Table 3. Incidence of traumatic head and brain injury in different countries.

\begin{tabular}{|c|c|c|c|}
\hline Country & Year & $\begin{array}{l}\text { Incidence } \\
1100,000\end{array}$ & $\begin{array}{l}\text { Admission rate } \\
/ 100,000\end{array}$ \\
\hline England & 1972 & - & 270 \\
\hline Scotland & $1974-6$ & .. & 313 \\
\hline Scotland $10 y$ & 1985 & 1967 & - \\
\hline France & 1986 & - & 281 \\
\hline Spain 12 ! & 1988 & - & 91 \\
\hline Sweden & 1984 & - & 249 \\
\hline Itally $(14)$ & $1984-5$ & 849 & 372 \\
\hline Norway & 1993 & 229 & 169 \\
\hline Denmark (16) & 1997 & - & 235 \\
\hline $\mathrm{US}^{(17)}$ & $1985-7$ & 793 & 132 \\
\hline US ${ }^{(6)}$ & 1991 & 618 & 158 \\
\hline Netherlands & 1997 & 836 & 88 \\
\hline
\end{tabular}

haematoma did not die. All other patients did not have intracranial changes that needed neurosurgical intervention. Of an a-selective sample of 100 patients for whom we checked general patient information, 21 were found to be resident outside the azM catchment area. 


\section{DISCUSSION}

The interpretation of data from the literature about the incidence and prevalence of minor traumatic head or brain injury is complicated by differences in definitions, criteria for admittance and the structure of the health care system in different countries. Frequencies of admittance mostly reflect hospital policies, while death rates concern only small proportions of the total group of patients. The number of patients seen in the emergency room can be regarded as the most reliable source for estimating the incidence of traumatic head and brain injury. Earlier publications show that approximately $75 \%$ of patients with brain injury seek medical attention ( $15 \%$ from the general practitioner, $35 \%$ at the emergency room, 25\% admitted to hospital). (6) Of the total population visiting the azM emergency room in 1997, 7\% had a traumatic head or brain injury. Of these injuries, 99\% were classified as minor (the sum of trauma capitis and minor brain injury cases). Of the total group with traumatic head or brain injury, $26 \%$ suffered from brain injury.

Table 3 shows the incidence of traumatic head or brain injury in our study compared with the numbers from other studies. $(3,6,9-17)$ The highest incidence in Europe was found in Scotand $(1967 / 100,000)$.(10) Sosin et al reported an incidence of 618 minor head or brain injuries per 100,000 inhabitants per year in the United States. (6) The total incidence of traumatic head or brain injury in the United States was estimated in the 'National Health Interview Survey 1985/87' as 793 per 100,000 per year. (17)

The incidence of admittance in our study was low compared to that reported in other studies $(88 / 100,000)$. The reason is probably that the patients seen at the AZM with minor injury are often discharged home with a printed waking advice. The fact that none of the patients sent home returned with complications leads to the conclusion that this admission policy is adequate.

The most common causes of traumatic head injury reported in the literature are falls, traffic accidents and violence, $(1,17)$ which is in agreement with our results $(43 \%, 22 \%$ and $15 \%$, respectively). It is striking that $50 \%$ of the moderate and severe brain injuries in our study were caused by traffic accidents; this percentage was substantially lower for the group as a whole.

The a-selective sample of 100 patients showed that $21 \%$ of the patients were resident outside the catchment area; this group consisted largely of tourists and 
university students. This has probably led to an (age-specific) overrating of our calculated incidence. Conversely, this percentage is probably partly compensated by patients from the adherent population who visit hospitals in other catchment areas with a traumatic head or brain injury. The magnitude of this group, however, is unknown. Because the data from the present study was corrected for several other sources of error, our data may be assumed to be reasonably reliable.

\section{REFERENCES}

1. Jennett B. Epidemiology of head injury. J Neurol Neurosurg Psychatry 1996,60(4):362-9

2. Murshid WR. Management of minor head injuries: admission criteria, radiological evaluam tion and treatment of complications. Acka Neurochir (Wien) 1998;140(1):56-64.

3. Jennett B, MacMillan R. Epidemiology of head injury, Br Med J Clin Res Ed $1981: 282(6258): 101-4$

4. McGregor $K$, Pentland $B$. Head injury rehabilitation in the U.K.: an economic perspective. Soc Sci Med 1997;45(2):295-303

5. wan Beeck EF, van Roijen L, Mackenbach JP. Medical costs and economic production losses due to injuries in the Netherlands. J Trauma 1997;42(6):1116-23

6. Sosin DM. Sniezek JE, Thurman DJ. Incidence of mild and moderate brain injury in the Unired States, 1991. Brain Inj 1996;10(1):47-54

7. Lawler KA, Terregino CA. Guidelines for evaluation and education of adult patients with mild traumatic brain injuries in an acute care hospital setting. J Head Trauma Rehabil $1996: 11(6): 18-28$.

8. Teasdale $G$, Jennett $B$ : Assessment and prognosis of coma after head injury. Acta Neurochir Wien) $1976 ; 34: 45$

9. Field JH. Epidemiology of head injuries in England and Walex. London: HMSO, 1976

10. Brookes M, MacMillan T, Cully S. Anderson E, Murray S, Mendelow AD, et al, Head inguries in accident/entergency departments. How different are childen from adult? J Epideniol Communicy Health 1990;44:147-51

11. Tiret L. Hausher $E$, Thicoipe $M$, et al. The epidemiology of head trama in Aquitaine (France), 1986: a community-based study of hospital admissions and deatrs, Int Epideniol $1990 ; 19(1): 133-40$

12. Vazquez Barquero A, Vazquez Barquero JL, Austin O, Pascuall, Gaite L, Herrera $S$. The epidemiology of head injuny in Cantabria. Eur J Epidemiol 1992;8(6):832-7

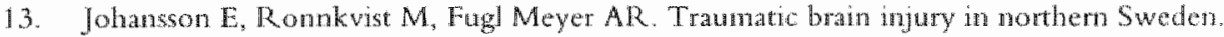
Incidence and prevalence of longrstanding impaiments and disabilities. Scand J Ralabil Med 1991,23(4):179-85. 
14. Servadei $F$, Ciucci $G$, $P$ iazza $G$, et a A prospective clinical and epidemiological study of head injuries in northem Italy: the Commune of Ravenna. Ital I Neurol Sci 1988;9(5): $449-57$

15. Ingebrigtsen $T$, Mortensen $K$, Romner $B$. The epidemiology of hospital-referred head injury in northern Norway. Neuroepidemiology 1998;17(3):139-46.

16. Duns BR. An audit on gudelines used for the initial management of patients with minor head injuries in Demmark. Acta Neurochir Wien 1997;139(8):743-8.

17. Kraus et al. Epidemiology of brain injury. In: Narayan RK, Wilberger JE, Povlishock JT, eds. Neurotrauma, New York; Mc Graw-Hili 1996:13-30. 


\section{CHAPTER}

\section{MANAGEMENT OF}

MILD TRAUMATIC BRAIN INJURY

Lack of Consensus in Europe

Presented at the III meeting of the European Federation of Neurological Societies; September 19-25, 1998; Seville

\section{Adapted from:}

I. do Kruijk. P. Leffers, 5. Meerhoff and A. Twijnstrat.

Management of mild tramatic brain injury: lack of consensus in Europe. Brast Inj $2001 ; 15(2): 117-124$ 


\section{ABSIRACI}

Mild traumatic brain injury (MTBT) accounts for most of traumatic brain injunies and is an important cause of morbidity. Recent studies in vanious European countries have shown that no consensus exusts about nanagenent of patients with MTBI This study describes the management of MTBI patients in various European hospitals A short questionnaire covering the areas of interest was sent 0 several EFNS members in European countries: The results of the inguiry show that there is at present no consensus about criteria for or management of MT BI in European hospitals. 


\section{INTRODUCTION}

Over the past 25 years, interest in the management of severe brain injury has increased. In contrast, mild traumatic brain injury (MTBI) is attracting much less attention, despite the fact that MTBI accounts for $80-90 \%$ of cases of tramatic brain injury. $(1,2)$ MTBI is an important cause of morbidity, especially in young people. Recent studies in the Netherlands, Gemany and Norway have shown that no consensus exists about indications for the use of radiodiagnostics or about the management of patients with MTBI.(3-5) The present study describes the management of MTBI patients in various European hospitals. The results may be useful as background information for the development of guidelines for the management of MTBI in Europe. Development of such guidelines was proposed at a special workshop during the third meeting of the European Federation of Neurological Societies (EFNS) in Seville, October 1998.

\section{METHODS}

A short questionnaire was designed to cover the areas of interest for our study (table 1). There were 5 main topics: 1. diagnosis and criteria for MTBI, 2. guidelines for management of MTBI, 3. diagnostics in MTBI, 4. hospital admission following MTBI and 5. advice to patients with MTBI. We defined MTBI as: "closed head injury followed by a Post-Trammatic Amnesia (PTA) lasting less than 1 hour and/or loss of consciousness (LOC) lasting less than 15 minutes". Although more than one international definition for MTBI is accepted, this definition seems to represent really mild injury as is explained in the discussion. In 1997, the secretary of the "scientist panel on Neuro-traumatology" of the EFNS sent the questionnaire to at least one member in each European country. A reminder was sent two months later. The EFNS members were also encouraged to send the questionnaire to colleagues in their own country. 
Table 1. Inquiry 'Management of patients with mild head injury' sent to EFNS members in different European countries.

(1) Which diagnosis do you use in patients with closed head injury followed by short PTA $(<1$ howr $)$ and/ or short loss of consciousness $(<15 \mathrm{~min})$ ?

$\square$ Brain concussion $\quad \square$ Commotio cerebri $\square$ Mild brain injury

Mild contusilo cerebri D Other ...n...............................

(2) Do you use the following in classification of mild head injury:

$\begin{array}{lll}\text { Glascow Coma Score } & \square N_{0} & \square \text { Yes } \\ \text { Post-Traumatic Amnesia } & \square N_{0} & \square \text { EN ......... } \\ \text { Retrograde Amnesia } & \square N_{0} & \square \text { Yes } \\ \text { Loss of consciousness } & \square N_{0} & \square \text {........... min... min. }\end{array}$

(3) Are there guidlelines concerning management of mild brain injury

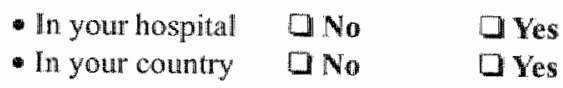

(4) Which investigations do you perform as a rule?

$\begin{array}{lll}\text { - X-skull } & \square \text { No } & \square \text { Yes } \\ \text { - X-cervical spine } & \square \text { No } & \square \text { Yes } \\ \text { - CT-brain } & \square \text { No } & \square \text { Yes } \\ \text { - MRl-brain } & \square \text { No } & \square \text { Yes } \\ \text { - EEG } & \square \text { No } & \square \text { Yes }\end{array}$

(5) Do you admit these patients to the hospital ?

$\square N_{0} \quad \square$ Yes

(6) If the patient is not admitted, which advice(s) do you give these patients?

- home observation program

$\square$ No

GYes

(waking up the patient every hour)

- to take fully bedrest

- to take sick leave

$\mathrm{N}$ No

$\square$ Yes... days

- pain medication

$\square$ No

$\square$ Yes ... days

$\square$ No

$\square$ Yes .. days

(7) Do you control these patients at least once?

$\square$ No $\square$ Yes

(8) Do you use separate guidelines for children

a Yes 


\section{RESULTS}

We received 67 questionnaires from 20 European countries (fig 1 ). As a result of the method used to distribute the questionnaires, we could not calculate response rates. Among the questionnaires returned, the various European countries were not equally represented. Some countries were represented by several responders, whille other countries were not represented at all. Sixty percent of all responses came from Eastern European countries. Among the Western European coumtries, we did not receive any responses from Spain or Ireland. The diagnostic terminology used for MTBI varied. 'Commotio cerebri ' was widely used (54\%), followed by 'Mild brain injury", 'brain concussion' and 'mild contusio cerebri' (fig 2). GCS, with cut-off levels between 10 and 15, was used as a clinical criterion for detining MTBI by $64 \%$ of responders. Length of LOC, with a tange of 2 to 60 minutes, was used as a criterion by $60 \%$ of the responders. Duration of PTA

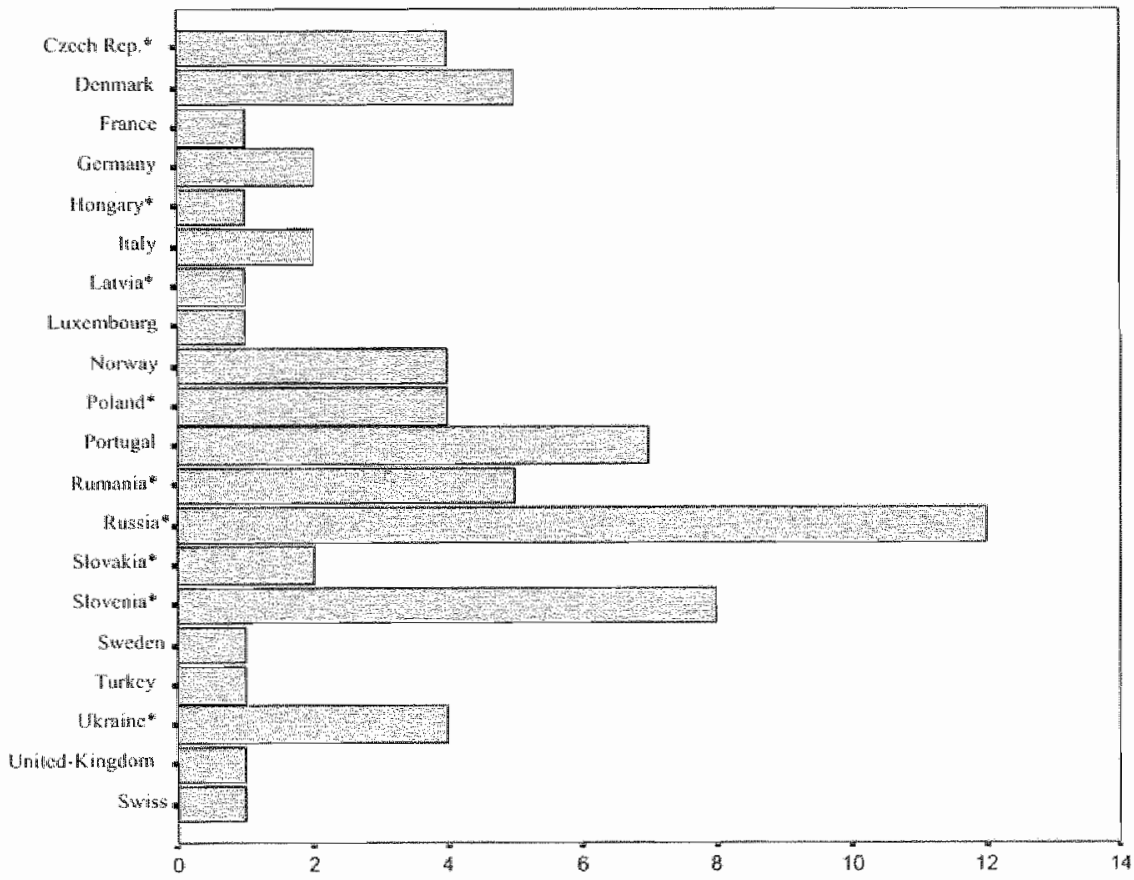

Fig 1. Origim of responders; ${ }^{*}=$ Eastern European country. 


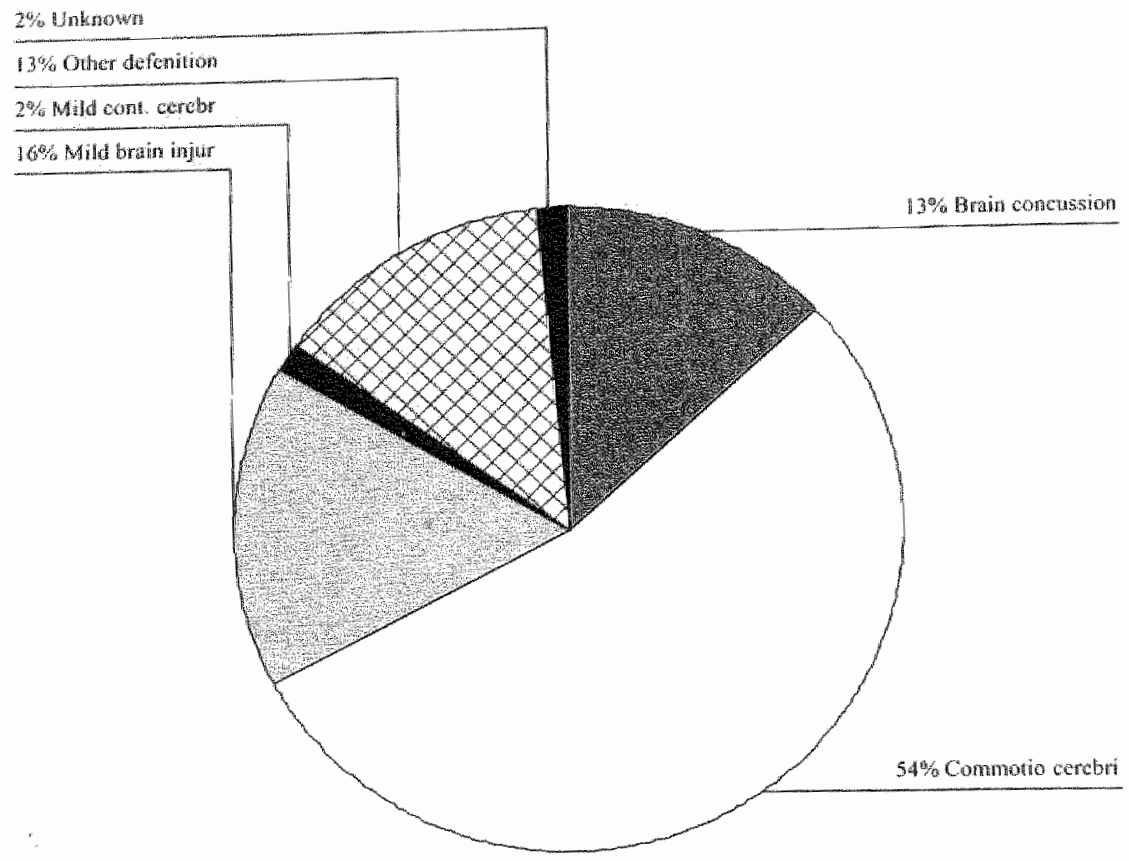

Fig 2. Diagnosis used for closed head injury followed by post-traumatic ammesialasting less than 1 hour and/or loss of consciousness lasting less than 15 minutes.

Was used as a criterion by $60 \%$ (table 2), with duration varying between 10 and 60 minutes. Diagnostacs used (table 3), included radiographs of the skull and cervical stine, performed by respectively $87 \%$ and $66 \%$ of the responders and $\mathrm{C} T$ scan and $M R$ of the brain, perfomed by respectively $66 \%$ and $9 \%$ of all responders. An EEG was ordered by $46 \%$ of the responders as part of the diagnostic work-up. Almost all responders $(94 \%$ reported admitting patients with MTBI to the hosputal for observation. Forty-one percent of responders advised patients to take bed rest for 1 to 14 days (toble 4). Sick leave from work was prescribed by $64 \%$, ranging from 1 to 30 days. At least one follow-up visit was considered necessary by $70 \%$ of responders. Local in-hospital guidelines for management of brain injury were used by $81 \%$ of responders; special guidelines for children were available in $49 \%$ of the hospitals. National guidelines were mentioned by $43 \%$ of responders. 
Table 2. Cinical criteria for mild traumatic brain injury used by responders to the inquiry.

\begin{tabular}{lclll}
\hline & Yes & No & Unknown & Cut-off values \\
\hline Clasgow Coma Scale & $64 \%$ & $30 \%$ & $6 \%$ & EMV 10-15 \\
Loss of consciousness & $60 \%$ & $22 \%$ & $18 \%$ & $5-60$ minutes \\
Post - tratumatic amnesia & $60 \%$ & $19 \%$ & $21 \%$ & $10-60$ minutes \\
\hline
\end{tabular}

Table 3. Diagnostics used by responders to the inquiry following mild traunatic brain injury.

\begin{tabular}{lllll}
\hline & Yes $\left(E W^{*}\right)$ & No & $\left(E N W^{*}\right)$ & Unknown $\left(E N W^{*}\right)$ \\
\hline Skull x-rays & $87 \%(98 \% / 69 \%)$ & $10 \%(2 \% / 23 \%)$ & $3 \%(0 \% / 8 \%)$ \\
CT-brain & $66 \%(63 \% / 69 \%)$ & $22 \%(22 \% / 23 \%)$ & $12 \%(15 \% / 8 \%)$ \\
MRI-brain & $9 \%(12 \% / 3 \%)$ & $54 \%(54 \% / 54 \%)$ & $37 \%(34 \% / 43 \%)$ \\
EEG & $46 \%(66 \% / 15 \%)$ & $37 \%(22 \% / 46 \%)$ & $23 \%(12 \% / 39 \%)$ \\
X-rays Cerv. Spine & $66 \%(83 \% / 39 \%)$ & $27 \%(7 \% / 42 \%)$ & $13 \%(10 \% / 19 \%)$ \\
\hline
\end{tabular}

${ }^{*} \mathrm{E} N=$ Easterm / Western Europe.

Table 4. Advice, given by responders to the inquiry, to patients with mild traumatic brain injury.

\begin{tabular}{lllll}
\hline & Yes & No & Unknown & Variation in length \\
\hline Home observation & $60 \%$ & $16 \%$ & $24 \%$ & \\
Bedrest & $41 \%$ & $25 \%$ & $34 \%$ & $1-14$ days \\
Sick leave & $64 \%$ & $6 \%$ & $30 \%$ & $1=30$ days \\
Follow-up examination & $70 \%$ & $30 \%$ & & \\
\hline
\end{tabular}

\section{DISCUSSION}

1. Diagnosis and criteria for $M T B I$. Our study shows that there is quite a variety of diagnostic nomenclature for MTBI. Several diagnoses are currently used for the same clinical entity in Europe. Notwithstanding the improvement in the accuracy of MTBI classification on the basis of GCS, PTA and duration of LOC at presentation, our questionnaire showed that a considerable number of responders failed to use these diagnostic criteria. In the medical literature, MTBI is defined by a GCS of 13-15 and a PTA shorter than 24 hours.(6-8) More 
recently, the range of GCS was limited to 15 , based on the absence of abnormalities in brain-CT of patients with GCS 15.(1,9) Because, by definition, a GCS of 15 means no ongoing PTA, a short PTA $(<1$ hour) is suggested for real mild brain injury. (8) The term minor brain injury has also been suggested for this.(10) As long as no consensus exists about the criteria to be used for MTBI, comparing results of various studies concerning the incidence and management of MTBI remains impossible

2. Guidelines for management of MTBI. Although most responders use in-hospital guidelines for the management of adult patients with MTBI, half of them did not have special guidelines for children. National guidelines were reported to exist in 12 of 20 countries; but in only 6 countries did all responders report the existence of guidelines. A future European consensus would hopefully lead to uniform guidelines in all European countries.

3. Diagnostics in MTBI. Diagnostics used following MTBI aim to discover possible traumatic intracranial complications, especially epidural haematomas. The large number of MTBI patients and the low prevalence of epidural haematomas, has led to much debate about indications for skull radiography. Over the last decade, several authors have suggested various guidelines for performing plain skull radiographs or CT-scans of the brain following MTBI.(2, 9-11) An early CT scan, if available, seems preferable to skull radiography. (11) The results of the present study show that many colleagues still use plain skull radiographs in the management of patients with MTBI. This method was used more frequendy in Eastern European countries than in Western European countries ( $97 \%$ and $69 \%$ respectively). More than half of all responders (66\%) used CT of the brain, while some performed both. A few responders (all from Denmark) perform neither plain skull radiographs nor CT of the brain. The preference of Eastern European responders for plain skull radiography cannot be explained from a lack of availability of CT-scan equipment, because this diagnostic method was used by almost the same numbers of responders in Western and Eastern European countries ( $63 \%$ and $69 \%$ ). It has been proposed that performing radiographs of the cervical spine in head-trauma patients is only useful in the case of neck pain and/or neurological abnormalities.(12) Nevertheless, $83 \%$ of Eastem European responders, and $39 \%$ of Western European responders performed cervical spine radiographs. Although according to current views, there is no indication for performing EEG in MTBI patients, (1.3) almost half of the responders 
performed an EEG (66\% of Eastern European responders and $15 \%$ of Westarn European responders).

4. Admission following MTBI. Although the incidence of patients admitted to hospitals with MTBI in Europe is not known, the present study shows that many patients with MTBI are being admitted. Admission rates of MTBL patients can be reduced by using guidelines for admission.(14, 15) Clinical observation seems useful only in patients with depressed level of consciousness, evidence of skull fracture, difficulty in clinical assessment because of alcohol, drugs or age and lack of a responsible carer.

5. Advice to the patient. Almost two-thirds of the responders gave home observation instructions' to patients with MTBI. These instructions were given to detect intracranial haematomas during the first 24 hours following brain injury and should be given in writing and/or verbally to a responsible person accompanying the patient.(16) Compliance with the advice is probably low.(17) Patients with MTBI who are discharged from the emergency department should also receive advice regarding activities in the immediate future. As our results show, sick leave is prescribed more frequently than bed rest. The majority of responders performed at least one follow-up examination for patients with MTBI. Guidelines concerning mobilisation following MTBI are meant to prevent the development of post-traumatic complaints. Scientific proof of the efficacy of bed rest and sick leave on the development of post-tramatic complaints is insufficient. If there is any effect of bed rest and sick leave, there is some evidence that the effect is better when it is limited to a few days instead of a few weeks. (18) Other studies have indicated that guidelines for treatment and information about the severity of complaints and prognosis can result in the prevention of post-concussional complaints. (19)

\section{CONCLUSION}

Notwithstanding the unequal representation of the various European countries in this study, it is clear that there is currently no consensus about management of MTBI in European hospitals. Guidelines for the management of MTBI should be developed by a European group and should be preceded by consensus about criteria for diagnosing MTBI. To create optimal support for the future imple- 
mentation of guidelines, it is important that inepresentatives of various professions involved in MTBI management should participate.

\section{ACKNOWLEDGEMENT}

The authors thank Professor Franz Gerstenbrand, Chaiman of the Scientist Panel on Neurotraumatology of the European Federation of Neurological Socicties in 1998 , for the distribution of the questionnaires.

\section{REFERNCES}

1. Culotta V, Sementilli M, Gerold K, Watts C. Clinicopathological heterogeneity in the classification of mild head injury. Neurosurgery 1996;38(2):245-250.

2. Servadei F, Giucci $G$, Loroni $L$, Cuscin $M$, Piola $C$, Arista $A$. Diagnosis and management of rminor head injury: a regional multicenter apptoach in Italy. J Trama Inj Infect Crit Care $1995 ; 39(4): 696-701$.

3. Kruijk de J, Twijnstra A, Leffers P. Geen uniformiteit in radiodiagnostiek en adviezen van Noderlandse netirologen bij patienten met licht hersenhersel. Ned Tijdschr Geneeskd $1996 ; 140(35): 1763-1765$

4. Ingebrigtsen T, Romner B. Managenent of minor head injuries in hospitals in Norway Acta Neurol Scand 1997;95:51-55.

5. von Wild $\mathrm{K}$. Terwey $\mathrm{S}$. Is mild traumatic brain injury a mistakable diagnosis? Lessons from clinical practice and an European Federation of Netrological Societies (EFNS) inquiry. European Journal of Neurology 1998;5(supplement 3):5235.

6. Rinel R, Giordan B, Barth J, Jane IA. Moderate bran injury: completing the clinical spectrum of brain tramma Newrosurgery $1982 ; 11(3) ; 344-51$.

7. Willians D, Levin H, Eisenberg H. Mild head injury classifaction. Neurosurgery $1990,27(3) \div 422-428$.

8. Alexander M. Mild tramatic brain ingury: pathophysiology, natural history, and clinical management. Nenrology $1995 ; 45: 1253-1260$.

9. Conez PA, Lobato RD, Ortega JM, De La CruzJ. Mid head injury: differences in prognosis anong patients with a Glasgow Coma Seale score of 13 to 15 and analygis of factors associated with abnomal. CT lindings. Br] Neurosurg 1996;10(5):453-60.

10. Vollmer D, Dacey R. The Management of mild and moderate head injunes. Neurosurg Clin North An 1991;2(2):437 455.

1. Ingebrigtsen $T$, Romner $B$. Trumpy I. Management of minor head injury: the value of early computed tomography and serum protein \$-100 measurements. I Clin Neuroso $1997: 4(1): 29) 33$. 
12. Kruijk de JR, Twijnstra A, Leffer $\mathbb{P}$, Wilmink JT. Röntgendiagnostiek bij hoofd-en/of nektrammata. Ned Tijdschr Traum 1994:5:119-125.

13. Kruger J, Vogt J, Stappenbeck C, Schoof C, Pressler M. EEG, CCT und MR bei patienten nach leichten und mitrelschwerem schadel-hirn-trama. Eine untersuchung bei 102 patienten. Nerwenarzt 1991;62:226-231.

14. Mendelow A, Campbell D, Jeffrey R, Miller J. Hessett C. Bryden J, et al. Admission after mild head injury: benefits and costs. BMJ 1982;285:1530-1532.

15. Miller J, Jones $P$, Dearden $N$, Tocher J. Progress in the management of head injury. Britust Joumal of Surgery 1992;79:60-64.

16. Saunders CE, Cota R, Barton CA. Reliability of home observation fort victims of mild closed-head injury. Ann Emerg Med 1986;15(2):160-3.

17. Lonw de A, Twijnstra A, Leffers A. Weinig uniformiteit an slechte therapietrouw bij het wetkadvies na rauma capitis. Ned Tijdsch Geneesk 1994;138(44):2197-2199.

18. 't Hooft van F. Commotio cerebri en andere gevolgen van schedeltraumata; ziekteverloop en prognose. Utrecht: Rijksuniversiteit Utrecht; 1973.

19. Minderhoud J, Boelens $M$, Huizinga J, Saan R. Treatment of minor head injuries. Clin Neurol Neurosurg 1980;82:127-140. 
s 


\section{CHAPTER}

\section{S-100B AND NEURON-SPECIFIC \\ ENOLASE IN SERUM OF MILD \\ TRAUMATIC BRAIN INJURY PATIENTS}

A comparison with healthy controls

Presented at the 51 st anmual meeting of the American Acadeny of Neurology; 1909 ;

Toronto: Canada

Adapted from:

Kruijk de J, Leffers $\mathrm{P}$, Menheere P, Meerhoff S, Twijnstra A.

S-100B and neuron-specific enolase in serum of mild tratumatic brain injury patients; $A$ comparson with healtay controls. Aat Neur Send 2001;103(3):175-179. 


\section{ABSTRACT}

Objectives: The aim of the study was to determine whether serum concentrations of Neuron-Specific Enolase (NSE) and S100-B in Mild Traunatic Brain Injury (MTBI) patients are higher than in serum of healthy controls. Material and methods: Blood samples from 104 MTBI patients were taken shortly after the trauma for measurement of S-100B and NSE in serum. In 92 healthy persons these markers were also measured. Marker concentrations in serum of patients and controls were compared. In the patient group the relation between serum-narker concentrations and clinical symptoms and signs, that occurred shortly after the traunatic event, were evaluated.

Results: Median NSE concentration was only slightly higher in patients $(9.8$ $\mu \mathrm{g} / 1,10$ to 90 percentile range 6.9 to $14.3 \mu \mathrm{g} / \mathrm{l})$ than in controls $(9.4 \mu \mathrm{g} / 1,6.3$ to $13.3 \mu \mathrm{g} / 1$ ). Median S-100B concentration was significantly higher in patients $(0.25 \mu \mathrm{g} / 1,0.00$ to $0.68 \mu \mathrm{g} / 1)$ than in controls $(0.02 \mu \mathrm{g} / 1,0.00$ to 0.13 4g/1). An association was found between $S-100 \mathrm{~B}$ concentrations and vomiting in patients.

Conclusions; $\mathrm{S}-100 \mathrm{~B}$ is a useful marker for brain damage in MTBI patients hid seems to be associated with the presence of vomiting after the trama. 


\section{INTRODUCTION}

Neuron Specific Enolase (NSE) and S-100B in serum and cerebrospinal fluid have been reported to be markers of cell damage of the human central nervous system. $(1,2)$ NSE is an iso-enzyme of enolase and is localized mainly in neurons but also in smooth muscle fibers and adipose tissue.(3) $\mathrm{S}-100$ is an acidic calcium-binding protein found in the brain as the iso-forms $\mathrm{S}-100 \mathrm{~B}(95 \%)$ and $\mathrm{S}-100 \mathrm{~A}(5 \%)$. (1) $\mathrm{S}-100 \mathrm{~B}$ is found in high concentrations in glial cells and Schwann cells and is highly specific for lesions of the central nervous system.

After brain tissue damage, increased concentrations of NSE and S-100B can be measured in peripheral blood serum. $(5,6)$ Serum S-100B and NSE concentration peaks are measured within 6 hours following traumatic brain injury, and these concentrations seem to reflect the severity of the mechanical disruption of the brain tissue (6-10) Serum S100-B concentrations shortly after severe brain injury do not only correlate with radiological abnormalities and clinical parameters such as the Glasgow Coma Scale score (GCS) and Marshall classification, but also with the Glasgow Outcome Scale. $(7,9)$ An association between early serum NSE concentrations and survival after severe head injury has been found by Yamazaki.(11) Woertgen found no association between NSE concentrations and the Glasgow Outcome Scale.(7)

The above studies related to severe brain injury, while most brain injury patients are classified as having mild traumatic brain injury (MTBI). In contrast to severe traumatic brain injury, not much is known about the pathophysiology and natural history of MTBI. Traumatically induced axonal damage (TIAD) is hypothised to be the pathophysiological mechanism in MTBI.(12) Biochemical markers confirming TIAD may be helpful in measuring the severity of brain damage. Indeed, elevated S-100B and NSE concentrations have been reported in MTBI(10, 13). However, the patient groups previously studied have been small and no control groups without brain injury were included.

The objectives of the present study were: 1) to measure whether serum concentrations of NSE and S-100B are elevated early after the onset of MTBI and 2) to study the association between serum concentrations and the presence of acute clinical symptoms in MTBI patients. 


\section{DESIGN AND METHODS}

Parients were eligible for this study if they met the following criteria for MTBI: 1) a blunt blow to the head resulting in post-traumatic amnesia (PTA) of less than 1. hour; 2) initial loss of consciousness (LOC) of less than 15 minutes; 3) GCS must be $>13$ on presentation at the emergency department and 4) absence of focal neurological signs.

Approval from the ethical committee review board was obtained prior to the study. During 1997 and 1998 , all patients presenting with MTBI at the emergency department of the Maastricht University Hospital were examined. Duration of PTA and presence of transient LOC were estimated on information from patient and witnesses. If patients arrived at the emergency department within 6 hours following the trauma and met the criteria for MTBI, infomed consent was asked for taking bloodsamples. Patients with alcohol abuse were excluded. Blood samples for NSE and S-100B measurement were taken within 6 hours after the tratma. The cause of the accident, sex, age and the presence of headache, nausea, vomiting and dizziness at first examination were recorded. Presence of traumatic injuries to limbs, trunk or head were also recorded. A group of 91 blooddonors without a history of traumatic brain injury in the past weeks were used as controls. Serum samples from these volunteers were obtained after informed consent.

All collected samples were sent immediately to the laboratory. The samples were allowed to clot and were centrifuged at $4000 \mathrm{~g}$ for 20 minutes at $4^{\circ} \mathrm{C}$. The serum was separated from the clot and stored at $-20^{\circ} \mathrm{C}$ until analysis. NSE was measured using a commercially available radioimmunoassay (Pharmacia NSE RIA, Pharmacia \& Upjohn, Uppsala, Sweden). This is al double antibody radioimmunoassy in which the NSE from the sample competes with a fixed amount of 125 - labelled NSE for the binding sites on an antibody raised in at rabbit. Separation between the bound and free fractions is obtained by the addition of a decanting suspension composed of Sepharose coated with sheep anti-rabbit antibody followed by centrifugation. The radioactivity of the pellet is inversely proportional to the quantity of NSE in the sample. The assay is calibrated by the manufacturer against purified NSE. The detection limit of the assay is better than $2 \mu \mathrm{g} / 1$. The total (intra-and inter-assay) coefficient of variation 
depends on the concentration, but is typically better than $7.5 \%$ at $6 \mu g / 1,4.7 \%$ at $19 \mu \mathrm{g} / 1$ and $8.4 \%$ at $90 \mu \mathrm{g} / 1$.

S-100B was measured using a commercially available immunoluminometric assay (LIA-mat Sangtec 100, Sangtec Medical, Bromma, Sweden). Polystyrene tubes were coated with mouse nonoclonal antibody versus S-100B. The S-100B from the samples react with this antibody during the first incubation. Next, all unbound material was removed by a washing step. During the following incubation a second labelled monoclional antibody, directed against a different epitope reacted with the bound $\mathrm{S}-100 \mathrm{~B}$, forming a sandwich structure. Once again all unbound material was washed away. The label consisted of an isoluminol derivative that is covalently bound to the second antibody. In alkaline solutions containing hydrogen peroxide the label emits a brief flow of photons, which was quantified in a luminometer. The light signal measured in RLUs (relative light units) was directly proportional to the amount of $S-100 \mathrm{~B}$ present in the sample. The detection limit of the assay is better than $0.03 \mu \mathrm{g} / 1$. The total (intra- and inter-assay) coefficient of variation depends on the concentration, but is typically better than $10 \%$ at $0.13 \mu \mathrm{g} / 1$, and better than $4 \%$ from $0.7 \mathrm{up}$ to $20 \mu \mathrm{g} / \mathrm{l}$.

Statistical analysis was done using SPSS 8.0. Distributions of serum concentrations of S-100B and NSE were visually evaluated in patients and controls. Especially S-100B showed non-Gaussian distributions. Accordingly, Wilcoxon's rank sum test was used for statistical testing of the difference in serummarker concentrations between subgroups. Associations of S-100B and NSE concentrations with age were evaluated using simple linear regression analysis. For the estimation of the serum concentration difference between patients and controls, adjustment for the incomparability in age and sex distributions between these groups was carried out using multiple linear regression analysis. Results are presented as the corrected difference between patients and controls (d) and the associated $95 \%$ confidence intervals (CI).

\section{RESULTS}

A) Serwm markers in controls and patients. Mean age of the 91 recruited controls was 40 years; $14 \%$ were female and $86 \%$ were male (table 1$)$. Median NSE and S-100B serum concentrations in controls were $9.4 \mu \mathrm{g} / 1$ and $0.02 \mu \mathrm{g} / 1$, respec- 
Table 1. Descriptives of MTBI patients and controls.

\begin{tabular}{|c|c|c|}
\hline & Controls & Patients \\
\hline N & 91 & 104 \\
\hline \multicolumn{3}{|l|}{ Cender } \\
\hline Male & $86 \%$ & $57 \%$ \\
\hline female & $14 \%$ & $43 \%$ \\
\hline \multicolumn{3}{|l|}{ Age (in years) } \\
\hline Mean & 40 & 36 \\
\hline Median & 40 & 36 \\
\hline Range & $17-63$ & $15-76$ \\
\hline $\mathrm{SD}$ & 14 & 16 \\
\hline \multicolumn{3}{|c|}{ S-100B serum conc (in $\mu g / h)$} \\
\hline Mean & 0.05 & $0.3 \pi$ \\
\hline median & 0.02 & 0.25 \\
\hline 10 and 90 percentile & 0.00 and 0.13 & 0.00 and 0.68 \\
\hline $\mathrm{SD}$ & 0.07 & 0.24 \\
\hline \multicolumn{3}{|c|}{ NSE serum conc $($ in $\mu g / l)$} \\
\hline Mean & 9.6 & 10.2 \\
\hline Median & 9.4 & 9.8 \\
\hline 10 and 90 percentile & 6.3 and 13.3 & 6.9 and 14.3 \\
\hline SD & 2.47 & 3.09 \\
\hline
\end{tabular}

dively. Means and percentiles are shown in table 1. No association was found between NSE and $S-100 B$ concentrations $(r=0.119 ; p=0.26)$. A significant association between $N S E$ and age was found $(\mathrm{Reg}$ coeff $=0.07 \mu \mathrm{L} / \mathrm{Lr} ; 95 \% \mathrm{CI}$ : 0.03-0.11). There was no association between S-100B and age. Median S-100B concentration was higher in female than in male controls $(0.05$ versus $0.00 \mu g / L$; $p=0.006$ ). The median NSE concentration in serum of male controls was higher than in serum of fomale controls $(9.7$ versus $7.6 \mu \mathrm{g} / \mathrm{L} ; \mathrm{p}=0.037)$.

104 MTBI patients were included in the study. Causes of trauma included traffic accidents (47\%), accidents in and around the house (19\%), accidents at work $(12 \%)$, sports accidents $(8 \%)$ and battering $(8 \%)$. In $7 \%$, of cases the cause of trama was unknown. Mean age was 36 years; $43 \%$ were female and $57 \%$ male (table 1). Median NSE and S-10OB serum concentrations in patients were 9.8 


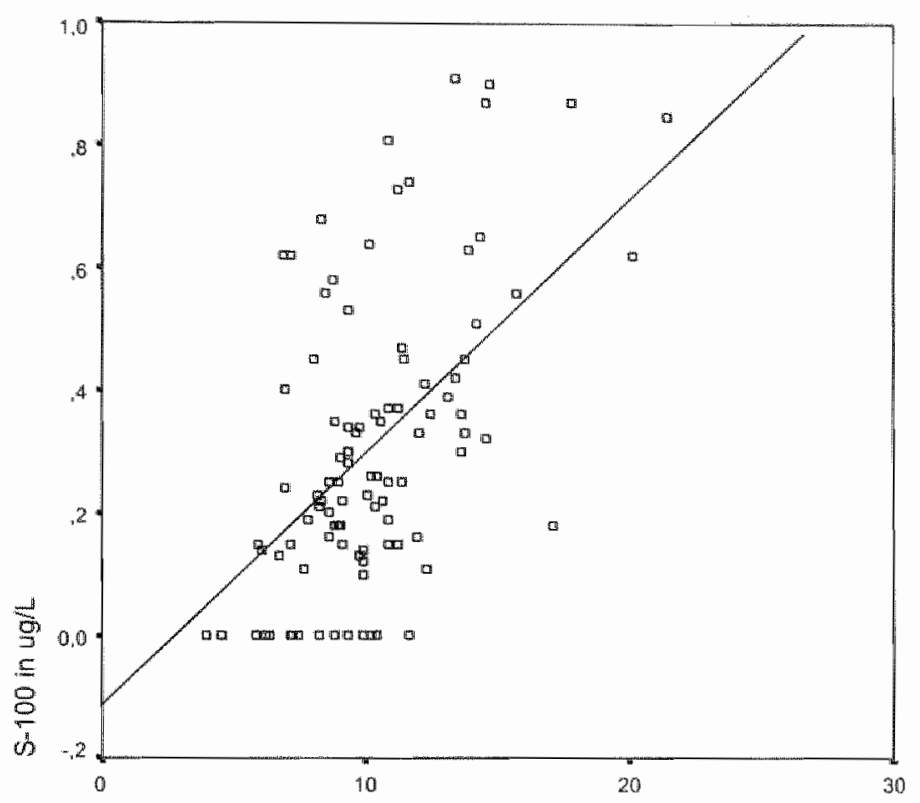

NSE in ugdL

Fig 1. Correlation of serum NSE and S1DO-B concentrations in patients within six hours after a mild traumatic brain injury.

$\mu \mathrm{g} / 1$ and $0.25 \mu \mathrm{g} / 1$ respectively. Means and percentiles are shown in rable $1 . \mathrm{A}$ statistically significant correlation was found between NSE and $\$ 100$ serum concentrations ( $\mathrm{r}=0.5 ; \mathrm{p}=0.0001$ for Speamann"s rho) in MTBI patients (fig. 1 ) NSE concentrations in patients were significantly higher than in controls after correction for differences in age and sex distributions between the groups $(\mathrm{d}=0.87 \mu \mathrm{g} / \mathrm{1} ; 95 \% \mathrm{CI}: 0.01-1.74) . \mathrm{S}-100 \mathrm{~B}$ concentrations were also significantly higher in MTBI patients than in controls $(d=0.26 \mu \mathrm{g} / 1 ; 95 \% \mathrm{CI}: 0.21-0.31)$. This difference did not change after correction for age and sex $(\mathrm{d}=0.23 \mu \mathrm{g} / \mathrm{1}, 95 \% \mathrm{Cl}$ : $0.18-0.29$ ).

In order to assess the potential diagnostic relevance of the markers, the distribution of serummarkers concentrations in patients and in controls are given in fig 3 . The distribution of NSE concentrations in patients and controls showed considerable overlap (fig $2 A$ ). The overlap for $S-100 B$ was much smaller (fig $2 B$ ). 


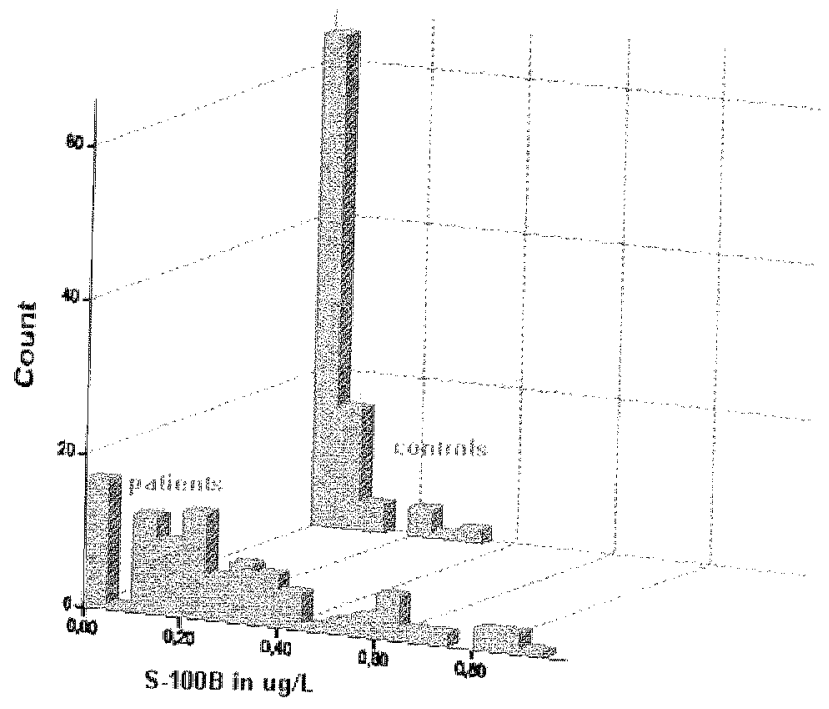

Fig 2A. S-100 B serum concentrations in controls and mild traumatic brain injury patients.

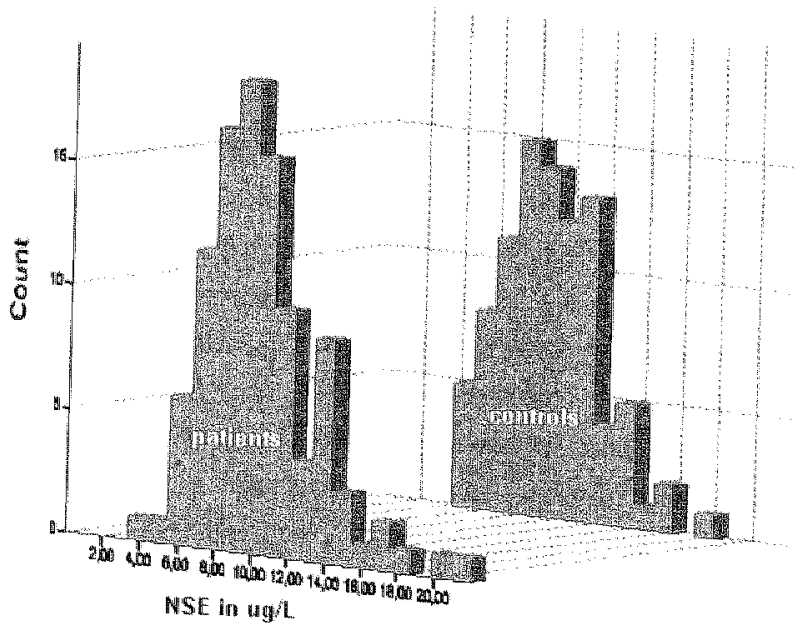

Fig 2B. NSE serum concentrations in controls and mild tratmatic brain injury patients. 
mean $17 \mathrm{~min}$.
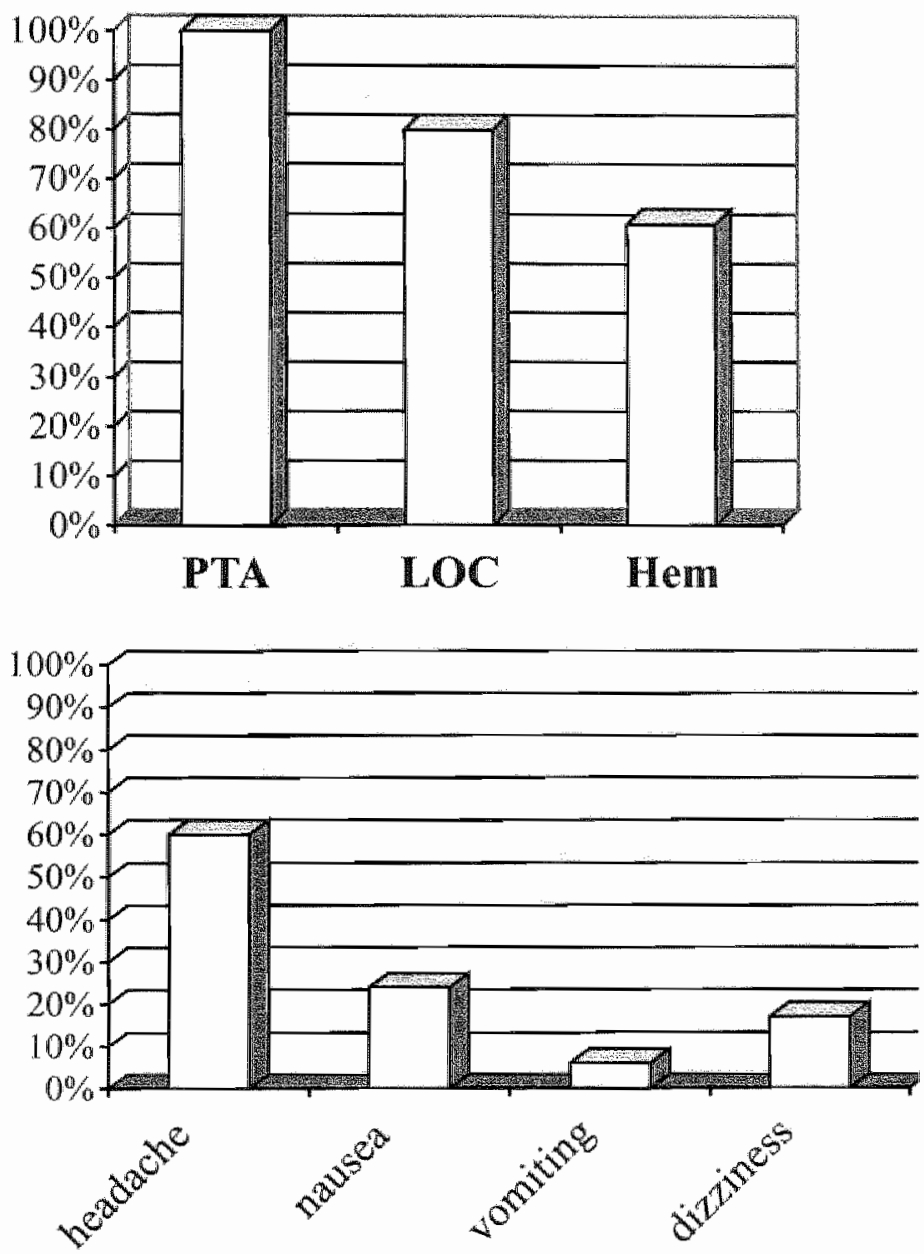

Fig 3. Trauma features (fig $3 A$ ) and acute symptoms (fig 3B) in patients with mild traumatic brain injury.

(PTA $=$ post-traumatic amnesia, $L O C=$ loss of consciousness, thern $=$ hemattoma"s of limbs, trumk and/or head) 


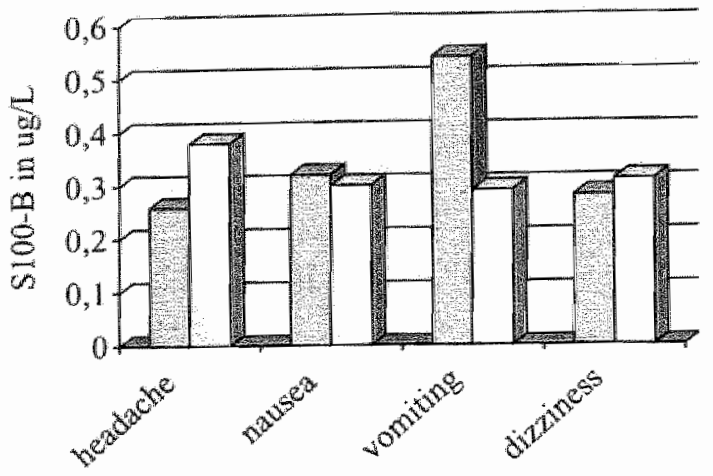

present

$\square$ absent

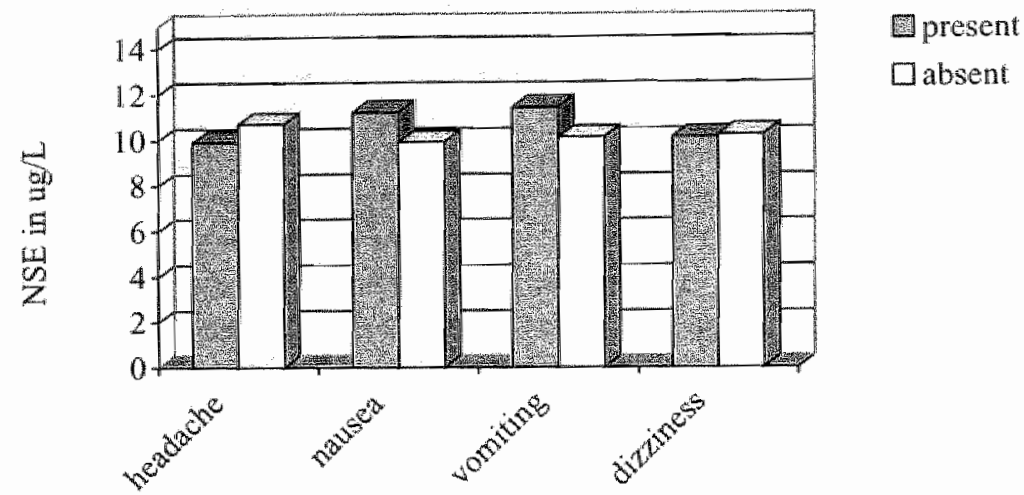

Fig 4. Biochenical marker concentrations and acute symptoms in patients with mild traunatic brain injury.

B) Symptoms and serum markers in patients. Mean PTA was 17 minutes, and transient LOC was reported in $80 \%$ of patients. $61 \%$ of patients were diagnosed with hematoma's of limbs, trunk and/or head (jo $3 A$ ). Headache, nausea, vomiting and dizziness at first examination after the trauma was reported in $61 \%$, $24 \%, 6 \%$ and $17 \%$ of cases respectively $(f i g)$.

No association was found between serum marker concentrations and either length of PTA, reported LOC or the appearance of hematoma's to limbs, trunk and/or head. There was no association between the serum-marker concentrations and the symptoms nausea and dizziness (fig 4). Patients who yomited 
however, had a higher median $\$ 100-B$ concentration than patients who did not $(0.5 \mu \mathrm{g} / 1$ vs $0.25 \mu \mathrm{g} / \mathrm{l} ; \mathrm{p}=0.03)$. Patients with headache however had a lower median $S-100 B$ concentration than patients without headache. $(0.21 \mu \mathrm{g} / \mathrm{l}$ vs $0.33 \mu \mathrm{g} / \mathrm{l} ; \mathrm{p}=0.02)$.

\section{DISCUSSION}

The present study investigated serum NSE and S-100B concentrations in a group of patients with clearly defined MTBI and a group of non-trauma controls. Distribution of age, sex and cause of accident in our patient group were simular to those in other MTBL studies. The mean serum S-100B concentration $(0.31$ $\mu \mathrm{g} / \mathrm{l})$ in patients in the present study was equal to what was found by Rothoerl in MTBI patients (defined as a GCS $>12$ ). (8) Although Ingebrigtsen reported no mean $S-100 B$ concentration in his study of 50 patients with MTBI (defined GCS 13-15), he found that concentrations were higher than $0.5 \mu \mathrm{g} / \mathrm{l}$ in $20 \%$ of cases $(10$ of 50 ). In the present study, $21 \%$ (22 of 104$)$ of $S-100 B$ values were higher than $0.5 \mu \mathrm{g} / 1$. The results with regard to serum $\mathrm{S}-100 \mathrm{~B}$ correspond with those of earlier MTBI studies, even though the criteria used for MTBI in the present study were stricter. This may be due to the fact that only a small fraction of patients in studies with more liberal criteria did not meet our stricter criteria.

There are no studies available in the medical literature allowing a comparison of NSE serum concentrations in MTBI patients with the mean concentration found in the present study $(10.2 \mu \mathrm{g} / \mathrm{l})$. However, in his study of patients with severe traumatic brain injury (GCS $<9)$, Woertgen found a clearly higher mean serum NSE concentration $(30.2 \mu \mathrm{g} / 1)$. (7) Skogseid reported elevated NSE concentrations $(>10 \mu \mathrm{g} / 1)$ in $31 \%(13$ of 42$)$ of MTBI patients (GCS $13-15)$. (10) In the present study, $44 \%$ ( 47 of 107) of the NSE concentrations measured were higher than $10 \mu \mathrm{g} / 1$. This difference is hard to explain, given the fact that the criteria for MTBI in the present study were stricter than those in Skogseid's study.

The present study shows that the median serum $\mathrm{S}-100 \mathrm{~B}$ concentration in a group of MTBI patients was clearly elevated compared to that in a group of healthy persons. A much less pronounced difference was found between the mean serum NSE concentrations in MTBI patients and controls. No association between serum-marker concentrations and traumatic damage to limbs, trunk and/or head 
was found. This finding makes it unlikely that damage to soft tissue or even peripheral nerves are responsible for the elevated serum-marker concentrations. Given the fact that the elevated serum marker concentrations is a consequence of brain injury, we can conclude that damage to brain tissue can be demonstrated even following MTBI, as defined in the present study. The distribution of NSE concentrations in patients and controls showed considerable overlap while the overlap for $\mathrm{S}-100 \mathrm{~B}$ was much smaller. As a consequence, determination of S-100B serum levels may prove to be a useful test for the presence of brain damage after MTBI, whereas increased serum NSE levels do not seem to be specific enough for MTBI to be useful for this purpose.

Keeping in mind that $S-100 B$ is a marker of damage to glial and/or Schwann cells, while NSE indicates damage to neurons, brain damage after MTBI is more likely to be localized in white matter than in gray matter. Since white matter is covering the axonal structures, this conclusion seems in accordance with the hypothesis that TIAD is an important pathophysiological mechanism in MTBI. The median S-100B concentration of the 6 patients who vornited after the trauma was significantly higher than the median S-100B concentration of those patients who did not. No association was found between clinical parameters nausea, dizziness and serum marker concentrations. In a recent study, Nee concluded that post-traumatic vomiting was associated with a fourfold increase in the risk of a skull fracture.(14) Both, severity of damage to the brain and fracture of the skull, depend on the impact of the trauma. If S-100B is a marker for severity of brain damage, both studies show the relationship between the impact of the trauma and post-traumatic vomiting after MTBI. We have no explanation for the fact that $S-100 \mathrm{~B}$ serum concentration was decreased among patients with headache. In conclusion, $\mathrm{S}-100 \mathrm{~B}$ is a potentially useful marker for brain damage in MTBI. A follow-up study to determine the predictive value of serum markers for the occurence of post-concussional complaints is in progress. 


\section{REFERENCES}

1. Persson L, Hardemark H, Gustafson ], et all. S-100 Proten and Meuron-Specific Enolase in cerebrospinal thid and serum: markers of cell damage in central nervous system. Sirkk $1986: 18911-18$

2. Lamers $K$, van Engelen B, Gabreels F. Hommes O, Borm G, Wevers R. Cerebrospinal Neuron-Specific Enolase, $S-100$ and Myelin Basic Protein in neurological disorder. Atta Newrol Sand 1995:92:247-51.

3. Kato K. Ishiguro $Y$, Suzuki F, fro A. Semba $\mathbb{R}$. Distribution of nervous system-specific toms of Enolase in peripheral tissues. Brain Res 1982:237:441-48.

4. Usu A, Kato K, Abe T. al e. S-100ao protein in blood and wine during open-heart surgery. Clinical Chemis 1989:35:1942-44.

5. Yamakami I, Yamaura A, Isobe 1. Types of brain ingury and regional cerebral blood tow assessed by 99mTc-HMPAO SPECT. Newrol Med Chr (Tokyo) 1993:33:7-12.

6. Raabe A, Menon D, Gupta S, Czosnyka M, Pickard J. Jugular venous and arterial concentrations of serum S-100B protein in patients with severe head injury: a pilot sudy. I Nownl Neurosurge Pspdiatry 1998:65:930-32.

7. Woertgen C, Rothoen D, Holzschuh M, Metz C, Bramanski A. Comparison of Serial S-100 and NSE serum neasurements after severe head injury. Aor Newrohir (Whin) $1997: 139: 1161-65$

8. Rothoerl R, Woertgen C, Holzhusch M. Metz C, Brawanski A. Sw100 serum levells after minor and major head injury. I Tram 1998:45:765-67.

9. Raabe A, Grolns C, Keller M, Dohnert J, Sorge O, Seifert V. Association of computed tomography findings and serum brain damage markers following severe head injury. Afo Netrohirg (Wion) 1998:140:787-91.

10. Skogseid I, Nordby H, Urdal P, Paus E, Lilleass F. Increased serum Creatine Kinase BB and Neuron Specific Enolase following head injury. Acta Nowmir (Wien) 1992:115:106-11.

11. Yamazaki $Y$, Yada K, Morri S, Kithahara $T$, Ohwada T. Diagnostic Significance of serum Neuron-Specific Enolase and Myelin Basic Protein assay in patients with acuta hod injury. Surg Neurol 1995:43:267-71.

12. Povlishock JT, Jenkins LV. Are the pathobiological changes evoked by traumatic bain injury immediate and irreversible? Brain Pathol 1995:5:415-26.

13. Ingebrigtsen $T$, Romner $B$, Trumpy J. Managenent of minor head injury: the value of early computed tonography and serum proteñ S-100 measurements. J. Clin. Neuroscience $1997: 4: 29-33$

14. Nee PA, Hadfield JM, Yates DW and Faragher ED. Significance of vomiting after head injury. I Newrol Newrosurg Pydataty 1999;60:470-473. 


\section{CHAPTER}

\section{OLFACTORY FUNCTION AFTER MILD TRAUMATIC BRAIN INJURY}

Presented at the 53rd annual meeting of the American Acadeny of Neurology, 2001; Philladelphia, USA

\section{Adapted from:}

J.R. de Kruijk, P. Leffers, P.P.C.A. Menheere, S. Meerhoff, I. Rutten and A. Twinstra.

Olfactory function after Mild Traumatic Brain Injury; submithed 


\section{$A B S \cap A C T$}

Olfactory dysfunction after mild traumatic brain injury (MTBI) has not been described before. The present study estimated the prevalence of quantitative olfactory dysfunction after MTBI. Associations of early symptoms and S-100B amd NSE serum concentrations with threshold levels of olfactory functions two weeks after MTBI were also examined. The prevalence of olfactory dysfunction two weeks after MTBI was $26 \%$. Mean olfactory threshold level was found to increase with age, at a rate of 0.5 decismel per year. No associations were found between acute parameters of MTBI and olfactory threshold levels. 


\section{INTRODUCTION}

The occurrence of olfactory dysfunction after traumatic brain injury has been described in particular after skull-base fractures and occipital blows (with frontal impact) to the head. (1-3) It is believed that olfactory information is processed by the olfactory tract via the olfactory bulb to the enthorhinal cortex (primary sensory areas) and the orbitofrontal cortex (secondary sensory areas).(4) Therefore, olfactory dysfunction after traumatic brain injury could not only be a result of shearing of the olfactory nerve filaments, (3) but might also be explained by damage to fronto-temporal cortical structures.

Experimental animal models and post-mortem studies in mild traunatic brain injury (MTBI) patients have shown axonal damage, mainly located in the frontal lobes. (5) These findings were clinically supported by abnormalities on MRI of the brain and elevated serum concentrations of specific markers of brain damage $(6,7)$ Confirmation of olfactory dysfunction after MTBI would support the hypothesis that such a relatively mild trauma can nevertheless damage structures of the brain somewhere in, or between, the olfactory nerve filaments and the fronto-temporal cortical structures.

The aim of the present study was to determine the prevalence of olfactory dysfunction 2 weeks after MTBI. Additionally, associations of early symptoms (headache, dizziness, nausea and vomiting) and biochemical serum markers (S-100B and NSE) with olfactory threshold levels were investigated.

\section{METHODS}

Participants. The study was conducted at the University Hospital in Mastricht, and the study was approved by the ethics committee of this centre. Each patient provided written informed consent. Patients were eligible for the study if they were at least sixteen years of age and presented at the emergency room within six hours after the trauma. MTBI was defined as a blunt blow to the head resulting in 1) PTA of less than 1 hour; and/or 2) initial LOC of less than 15 minutes; 3) GCS of 14 or 15 on presentation at the emergency department; and 4) absence of focal neurological signs. Patients were excluded if they suffered from multiple trauma 
or if there was a need for clinical observation. Patients with a history of traumatic brain injury, alcohol abuse or psychiatric disorder were also excluded.

Quantitative olfactometry. Two weeks after the trauma, olfactory function was quantifed using a 'Hyposmia utility kit' (Olfacto-labs', El Cerrito, US). The test covered nine Phenyl Methyl Ethyl Carbinol (PM-Carbinol) concentrations with ranges of 10 decismels (dS) between -25 and $55 \mathrm{dS}$. The PM-Carbinol was presented to the patient (with both nostrils open) in at blank sniff bottle together with a blank odourless bottle. The patient had to select the bottle having the stronger odour. The threshold was the lowest concentration for which the patients correctly selected the PM-Carbinol bottle three consecutive times. According to the manufacturers, the normal range of olfactory thresholds ( $95 \%$ of subjects aged 20-70 years) is from -25 to $+25 \mathrm{dS}$. Between the ages of 10 and 70 years, the threshold is said to increase by $0.3 \mathrm{dS}$ per year. Differences between genders and between moderate smokers and non-smokers are negligible. Thresholds in the range of 30-55 dS represent hyposmia for the tested odour and any subject who cannot detect $55 \mathrm{dS}$ is considered to have no olfactory function for this odour. (8)

Study design. If patients fulfilled all admissibility criteria, printed and oral explanations about the study were given by the physician in attendance (neurology resident) and consent was asked for participation in the study. Symptoms at the ER were noted and blood samples for NSE and S-100B measurement were taken within 6 hours after the trauma. NSE and S-100B concentrations were measured using commercially available radioimmuno-assays for NSE (Pharmacia \& Upjohn, Uppsala, Sweden) and a immunoluminescenmetric-assay for $\$ 100 \mathrm{~B}$ (Sangtec Medical, Bromma, Sweden). Two weeks after the trauma, patients were seen at the outpatient clinic for quantitative olfactometry.

Analysis. Baseline data, including demographics, symptoms and serum marker concentrations at the ER, were described. Olfactory threshold values at two weeks after the trama were compared with normall values as provided by Olfacto-labs ${ }^{12}$. The increase in the olfactory treshold values with age was analysed with linear regression analysis. Finally, the associations between olfactory threshold values at two weeks and individual symptoms and serum marker concentrations at the ER were examined, using multiple linear regression analysis with adjustment for the influence of age. 


\section{RESULTS}

Between October 1996 and December 1998, we examined 61 males and 50 females with MTBI and no other neurological disorders. Median age was 34 years (table 1). The olfactory threshold values measured two weeks after the trauma ( $f g$ 1) ranged from -15 to $>55 \mathrm{dS}$. The normal range of olfactory thresholds (95\% of subjects aged $20-70$ years) is -25 to $+25 \mathrm{dS}$. Twenty-four of our patients (22\%) had threshold values between 30 and $55 \mathrm{dS}$, defined as hyposmia. Five patients ( $4 \%$ ) were even unable to detect 55 dS (anosmia).

Seventy-four patients (66\%) gave consent for blood samples to be taken at the $E R$, and NSE and $S-100 B$ concentrations were each found to be elevated in $41 \%$ of patients. There was a positive association between age and olfactory thresholds $(b=0.48 \mathrm{dS} /$ year; $95 \% \mathrm{CI}: 0.33-0.64)$ (fig 2). After adjustment for age, linear regression analysis of olfactory thresholds at two weeks showed no significant associations with the presence of symptoms at the ER (table 2), nor with early concentrations of $\mathrm{S}-100 \mathrm{~B}(\mathrm{~b}=-11 \mathrm{dS}$ per $\mu \mathrm{g} / \mathrm{l} ; 95 \% \mathrm{CI}-28-5 \mathrm{dS})$ or NSE $(\mathrm{b}=1$ $\mathrm{dS}$ per $\mu \mathrm{g} / 1 ; 95 \% \mathrm{CI} ;-2-1 \mathrm{dS}$ ) in the serum. 
Table 1. Patient characteristics assessed at the emergency room.

Demographic characteristics $(111$ patients)

Gender

Female

$45 \%$

Age in years

(median $34 ; 5-95$ percentiles $17-72$ )

$15-25$

$37 \%$

$26-35$

$21 \%$

$36-45$

$21 \%$

46-55

$12 \%$

$56-65$

$8 \%$

$>65$

$7 \%$

Presence of symptoms

Headache

$62 \%$

Nausea

$29 \%$

Dizziness

$18 \%$

Vomiting

$6 \%$

Serum markers (74 patients)

NSE (mean 9.77 . SD 2.92)

$\geq 10 \mu \mathrm{g} / \mathrm{l}$

$41 \%$

S-100B (mean 0.28; 500.22 )

$\geq 0.3 \mu g / 1$

$41 \%$

Table 2. Difference in offactory threshold between patients with and without symptoms at the ER.

\begin{tabular}{|c|c|}
\hline Symptoms presented at ER & $\mathrm{B}^{*}(95 \% \mathrm{Cl})^{5}$ \\
\hline Headache & $1 d S(-5106)$ \\
\hline Dizziness & 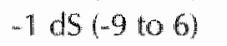 \\
\hline Nausea & $-2 d S(-8104)$ \\
\hline Voniting & $-2 d 5(-12$ to 9$)$ \\
\hline
\end{tabular}

* $B=$ difference in olfactory threshold between patients with and without symptoms at the ER: linear regression analysis of outcome variable (Olfactory threshold at two weeks) on acute symptoms after adjustment for age.

$\$ 95 \%$ Confidence interval for $B$.

$d S=$ decismel. 


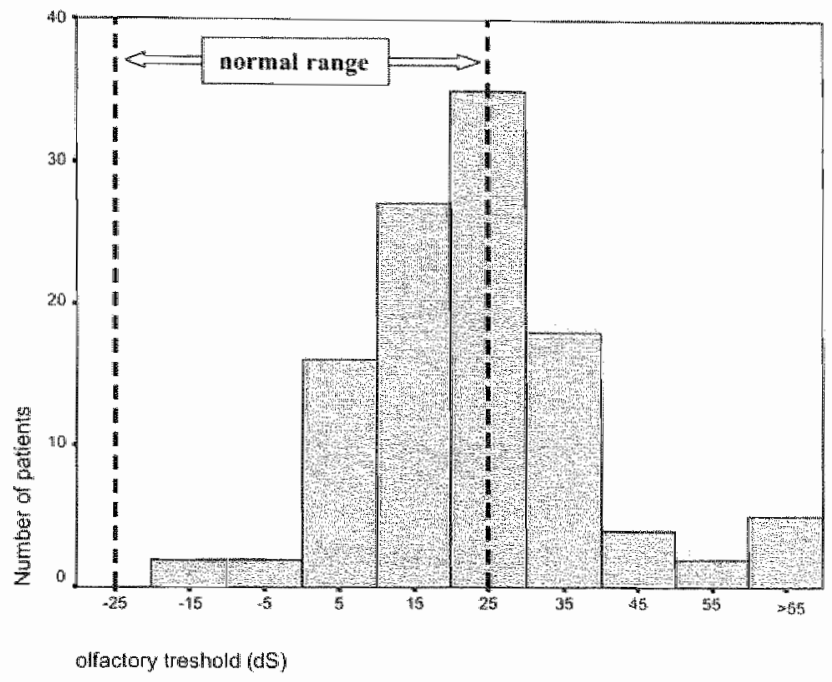

Fig 1. Quantitative olfactory function two weeks after mild traumatic brain injury in 111 patients.

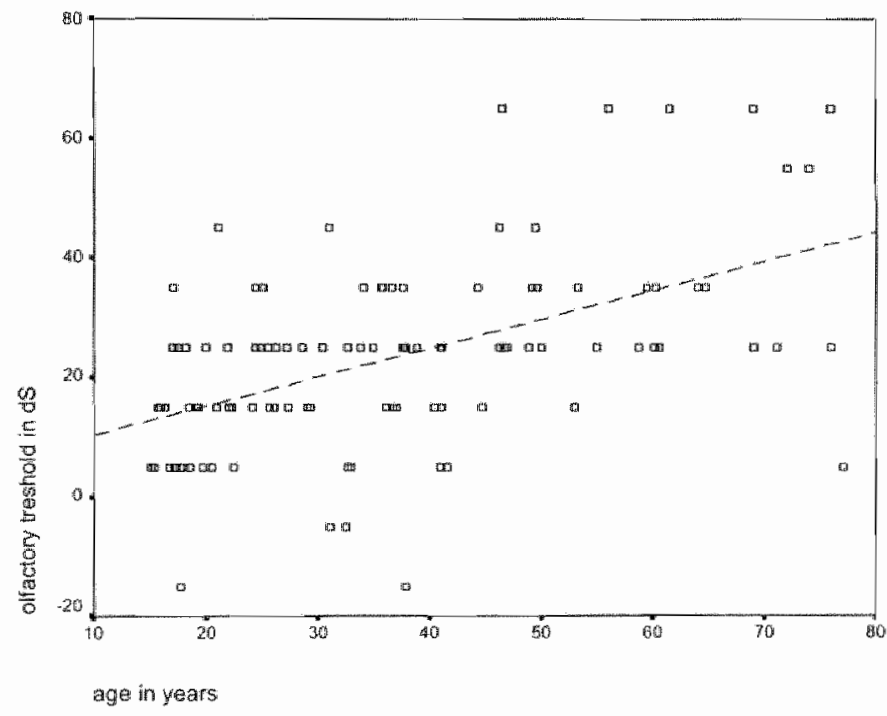

Fig 2. Association between age and olfactory threshold in mild traumatic brain injury patients. 


\section{DISCUSSION}

We found that a quarter of MTBI patients showed quantitative olfactory dysfunction after two weeks, while $22 \%$ showing hyposmia and $4 \%$ anosmia. As far as we know, no other prospective studies after MTBI are available to compare these findings with. In a normal population with similar age range, hyposmia has been found in $2 \%$ and anosmia has been observed in about $0.2 \%$ (data from Olfacto-labs $)$. With regard to age, we found that the threshold increased by almost $0.5 \mathrm{dS}$ per year, whereas according to the manufacturer of the test, the threshold should increase by $0.3 \mathrm{dS}$ per year in healthy controls. The fact that we found an association with age shows that we did indeed measure olfactory function. These findings support the idea that MTBI causes damage to the brain (olfactory nerve and/or frontal cortical structures). However, even though we found a high prevalence of olfactory dysfunction, we could not detect any correlation between olfactory dysfunction and acute parameters of MTBI. A retrospective study of 29 head injury patients with olfactory dysfunction by Schechter found no association between severity of injury and extent of olfactory dysfunction either.(2) This is surprising since acute MTBI parameters are associated with the severity of other outcome variables such as post-traumatic complaints. (Chapter 6)

One explanation for the unexpected combination of findings could be that olfactory dysfunction is associated with an aspect of the trauma that is unrelated to its acute parameters. Another possibility is that the reference values provided by the manufacturer of the smell test we used are not valid for our population or for the environment in which the test was applied. The test kit had not exceded its expiration date, nor did we detect any rise in measured thresholds over time. In future research, it is important to check the validity of the reference values by including a healthy local control group. 


\section{REFERENCES}

1. Richard L. A review of olfactory dystumctions in man. An J Otolaryngol 1979,1(1):57-79.

2. Schechter P, Henkin $R$. Abnomalities of taste and smell after head trauma. I Neutol Neurosurg Psychiatry 1974;37:802-810.

3. Shifman S. Mechanisms of disease. Taste and smell in disease. N Engl Med $1983 ; 308(21): 1275-1278$.

4. Savic I, Bookhemer S, Fried I, I E. Olfactory bedside test; A simple approach to identify temporo-orbitofrontal dysfunction. Arch Neurol 1997;54:162-168.

5. Povlishock J. Morphopathological change associated with mild head injury. In: mild head injury. New York: Oxford university press; 1989. p. 37-51.

6. Hofman P, Stapert S, van Kroonenburgh M, Jolles J, de Kruijk J, Wilmink J. MR Inaging, Single-photon Emission CT, and Neurocognitive Perfomance after Midd Tramatic Brain Injury. Am J Neuroradiol 2001;22:441-449.

7. Kruijk de J, Leffers P, Menheere P, Meethof S, Twijnstra A. S-100B and neuron-specific enolase in serum of mild traumatic brain injury patients; A comparison with healdy controls. Acta Neurol Scand 2001;103(3):175-179.

8. Sherman A, Amoore J. Weigel V. The pyridine scale for clinical measurementit of of olfactory threshold: a quantitative reevaluation. Otolaryngol Head Neck Surg 1979;87:717-733. 


\section{CHAPTER}

\section{PREDICTION OF POST-TRAUMATIC COMPLAINTS AFTER MILD TRAUMATIC BRAIN INJURY}

Early symptoms and biochemical markers 


\section{A BSTRACT}

Aim of the study: Early recognition of mild traumatic brain injury (MTBI) patients who are at risk of developing post-traumatic complaints (PTC) would be useful because early follow-up at the outpatient clinic might help to reduce the severity of these complaints in the long run. The aim of the present study was to identify clinical parameters at first presentation after MTBI that are predictive of the severity of post traumatic complaints after six monthis.

Findings: After six months, severity of most complants had declined to pre-trauma levels but medians for headache, dizziness and drowsiness were still elevated. In a series of 79 patients, 22 ( $28 \%$ reported one or more PTC after six months. After adjustment for baseline variables, an at least twofold increased severity of all PTC subgroups was reported by those patients reporting headache, dizziness and/or nawsea at the emergency room $(\mathrm{ER}) A$ twofold increased severity of 'cognitive' and 'vegetative' PTC was also found in, those with elevated concentrations of biochemical serum markers $(S-100 \mathrm{~B}$ and NSE) at first presentation. The prevalence of full recovery after six months increased from $50 \%$ in patients with three symptoms to $78 \%$ in those with no symptoms at the ER. Inclusion of biochemical narkers showed that all ten patients with no symptoms at the ER and normal markers recovered fully.

Conclusions: The presence of headache, dizziness and/or nausea at the ER after MTBI is strongly associated with the severity of most PTC after six months. Identifying MTBI patients at the ER without headache, dizziness, nausea of elevated serum marker concentrations may be a promising strategy for predicting good outcome. 


\section{INTRODUCTION}

Mild Traumatic Brain Injury (MTBI) accounts for about $90 \%$ of traumatic brain injuries (1-3). Although the mortality rate is negligible, the frequency of post-traumatic complaints (PTC) is appreciable. The severity of most PTC declines during the first three months, but the prevalence of having any complaints six months after the trauma is still estimated to be 20 to $80 \%$ (4-7). These PTC comprise a large number of symptoms, including headache, dizziness, drowsiness, loss of memory and concentration problems. It is believed that these complaints are caused by a combination of brain injury, psychological, emotional and motivational factors.

Educating patients shortly after MTBI at the outpatient clinic about the expected prognosis of possible complications might help to reduce the severity of PTC in the long run (8-10). Since many MTBI patients do not experience persistent PTC at all, reducing needless follow-up will save money and prevent medicalization of these mainly young and healthy people. Against this background, early recognition of patients who are not at risk of persistent PTC would be useful.

MTBI parients have been studied in order to find prognostic indicators of PTC $(2,7,11)$. It was found that female sex, more advanced age and prior MTBI are associated with poor outcome. Apart from headache within 24 hours after MTBI, which is also associated with poorer outcome $(2,7)$, no associations between presenting MTBI symptoms and outcome have been reported.

The predictive value of specific serum markers S-100B and NSE serum concen trations for the Glasgow Outcome Score after severe head injury has been established earlier $(12,13)$ and elevated NSE and S-100B serum concentrations were also found recently in MTBI patients within six hours after the trauma $(14,15)$. Although early elevated S-100B and NSE concentrations in serum seem to predict neuropsychological dysfunction $(16,17)$, the relationship between elevated biochemical marker concentrations and PTC after MTBI has not been. studied so far. 
The aim of the present study was to identify symptoms and biochemical markers at first presentation after MTBI that are predictive of the severity of post-tranmatic complaints six months later. In order to develop a clinically useful test to determine which MTBI patients do not require follow-up at the outpatient clinic, we also tried to find a combination of variables that could predict favorable outcome after six months.

\section{METHODS}

Participants. The study was conducted at the University Hospital of Maastricht, the Netherlands, as part of an intervention study on the efficacy of bed rest after MTBI. The study was approved by the hospital's ethics committee and each patient provided written informed consent. Patients were eligible for this study if they were older than fifteen years and presented at the ER within six hours after the tramna. MTBI was defined as a blunt blow to the head resulting in 1) post-traumatic amnesia of less than one hour and/or; 2) initial LOC of less than 15 minutes; 3) GCS of 14 or 15 on presentation at the emergency department; 4) absence of focal neurological signs. Patients were excluded if they suffered from multi-trauma or if there was a necessity for clinical observation. Patients with a history of traumatic brain injury, alcohol abuse or a psychiatric disorder were also excluded.

Predictive variables. The present study assessed the presence of symptoms at the ER (headache, dizziness, nausea, vomiting and neck pain) and biochemical markers (Neuron Specific Enolase and S-100B) in serum taken within six hours atter the tratma as possible predictive variables for the severity of PTC. Age, sex and intervention (bed rest within ten days after the trauma) were considered as possible confounders.

Outcone variables. Outcome variables were the severity of 16 PTC six months after the tratuma. Selection of these PTC was based on an earlier study which showed that these complaints differed in intensity from those in control subjects (18). The PTC were measured on visual analogue scales (VAS) and divided into four subgroups (cognitive, dysthymic, vegetative, and physical). Complaints assessed in the present study were very similar to the symptoms used in the 
Rivermaid Post Concussion Symptoms Questionnaire, which was developed and standardized by the Oxford Head Injury Service $(5,19)$.

Study design. If patients fulfilled all admissibility criteria, a written and oral explanation about the study was given by the physician in attendance (neurology resident) and consent was asked for participation in the study. The presence of headache, neck pain, nausea, vomiting and dizziness was recorded at first examination. Blood samples for NSE and S-100B measurements were taken within six hours after the trauma. NSE and S-100B concentrations were measured using commercially available immunoluminometric assays (Pharmacia NSE RIA, Pharmacia \& Upjohn, Uppsala, Sweden and LIA-mat Sangtec 100, Sangtec Medical, Bromma. Sweden). NSE and S-100B serum concentrations were defined as elevated if they were higher than, respectively, $10 \mu \mathrm{g} / 1$ and 0.3 $\mu \mathrm{g} / \mathrm{l}$. At the follow-up moments (two weeks and six months), all patients were questioned at the outpatient clinic about the severity of PTC. At first follow-up, patients were not only questioned about the severity of PTC at that moment, but also about the severity of these complaints before the trauma.

Statistical analysis. Baseline data including demographics, acute clinical symptoms and serum marker concentrations were summarized. Medians and 5 and 95 percentiles of VAS scores for all PTC were recorded for each follow-up moment. The sums of the VAS scores for the four subgroups of PTC after six months were also calculated and the interrelations between the severity levels of these four PTC subgroups were expressed as Spearman's correlation coefficients.

Because of their non-normal distribution, VAS scores were transformed to their natural logarithms (n). Associations between PTC after six months and possible predictive variables were estimated by multiple linear regression analysis, adjusting for gender, age and type of bed rest advise after trauma. Variables with a statistically significant association with PTC were selected and predictive values for combinations of these symptons were calculated. For this purpose, patients were divided into groups 'fully recovered" and 'not fully recovered' after six months. Patients were considered to be 'fully recovered' if the VAS scores of all PTC after 6 months were lower than the 95 percentile of the pre-traumatic VAS scores. If one or more VAS scores after six months were higher than the pre-traumatic 95 percentile, outcome was defined as "not fully recovered". 


\section{RESULTS}

Patient characteristics and acute variables. Between October 1996 and June 1999, 107 MTBI patients were enrolled in the study. After two weeks, 103 patients showed up for follow-up examination (96\%), versus $79(74 \%)$ after six months. Baseline variables were described for the 103 patients showing up after two weeks (table 1). Slightly more men than women were included (57\% versus $43 \%)$ in the study. More than half of the patients $(61 \%)$ reported headache at the ER. Nausea, dizziness, neck pain and vomiting were reported by $27 \%, 18 \%, 17 \%$ and $6 \%$ respectively. Fourteen patients $(13 \%)$ did not consent to have blood samples taken at the ER. Eventually, serum markers were measured in 89

Table 1 . Patients characteristics at the emergency room.

$\begin{array}{lr}\text { Demographic characteristics }(n=103) \\ \text { Gender } \\ \text { Female } \\ \\ \text { Age in years } \\ \text { (mean } 37.2 ; 15-75) & 43 \% \\ 15-25 & \\ 26-35 & 28 \% \\ 36-45 & 20 \% \\ 46-55 & 20 \% \\ 56-65 & 16 \% \\ >65 & 9 \% \\ & 7 \%\end{array}$

Acute symptoms

Headache

$61 \%$

Nausea

$27 \%$

Dizziness

$18 \%$

Neck pain

$17 \%$

Vomiting

$6 \%$

Serum markers $(n=89)$

NSE (mean $9.8 \mu g / l: 3.9-21.4 \mu \mathrm{g} / \mathrm{l})$

$\geq 10 \mu \mathrm{g} /$

$40 \%$

S. $100 \mathrm{~B}$ (mean $0.28 \mu \mathrm{g} / \mathrm{f}$; $\mathrm{SD} 0.02-0.90 \mu \mathrm{g} / \mathrm{l})$

$\geq 0.3 \mu \mathrm{g} / \mathrm{L}$

$38 \%$ 
Table 2. Severity of post-traumatic complaints at different follow-up moments.

\begin{tabular}{|c|c|c|c|}
\hline \multirow{2}{*}{$\begin{array}{l}\text { WAS }{ }^{*} \text { score of } \\
\text { post-traumatic complaints }\end{array}$} & \multicolumn{3}{|c|}{ Follow-up moment } \\
\hline & $\begin{array}{l}\text { Before trauma* } \\
\text { median }(5-95 \\
\text { percentile }\end{array}$ & $\begin{array}{l}\text { Two weeks }(\mathrm{n}=103) \\
\text { median }(5-95 \\
\text { percentile) }\end{array}$ & $\begin{array}{l}\text { Six months }(n=79) \\
\text { median }(5-95 \\
\text { percentile) }\end{array}$ \\
\hline \multicolumn{4}{|l|}{ Cognitive PTC } \\
\hline Trouble concentrating & $0(0-50)$ & $6(0-92)$ & $1(0-80)$ \\
\hline $\begin{array}{l}\text { Easily overwhelmed } \\
\text { by problems }\end{array}$ & $0(0-45)$ & $0(0-48)$ & $0(0-66)$ \\
\hline Forgetul & $1(0-45)$ & $10(0-60)$ & $1(0-70)$ \\
\hline Sum cognitive & $7(0-90)$ & $28(0-147)$ & $13(0.186)$ \\
\hline \multicolumn{4}{|l|}{ Vegetative } \\
\hline Flushing easilly & $0(0-53)$ & $0(0-41)$ & $0(0-20)$ \\
\hline Feeling short of breath & $0(0-55)$ & $0(0-63)$ & $0(0-52)$ \\
\hline Feeling faint & $0(0-59)$ & $0(0-59)$ & $0(0-53)$ \\
\hline Sum vegetative & $6(0-98)$ & $11(0-186)$ & $5(0-82)$ \\
\hline \multicolumn{4}{|l|}{ Dystimic } \\
\hline Depressed & $0(0-48)$ & $0(0-54)$ & $1(0-59)$ \\
\hline Drowsy & $0(0-43)$ & $13(0-94)$ & $3(0-90)$ \\
\hline Crying more easily & $0(0-41)$ & $0(0-51)$ & $0(0-19)$ \\
\hline Confused & $0(0-22)$ & $1(0-57)$ & $0(0-49)$ \\
\hline Sum dysthymic & $7(0-101)$ & $31(0-179)$ & $8(0-190)$ \\
\hline \multicolumn{4}{|l|}{ Physical } \\
\hline Headache & $1(0-59)$ & $12(0-97)$ & $3(0-75)$ \\
\hline Dizziness & $0(0-32)$ & $12(0-95)$ & $3(0-60)$ \\
\hline Nawsea & $0(0-14)$ & $0(0-58)$ & $0(0-26)$ \\
\hline Light-headed & $0(0-33)$ & $3(0-60)$ & $1(0-60)$ \\
\hline Paresthesia of $\operatorname{arm}(\mathrm{s})$ & $0(0-29)$ & $0(0-53)$ & $1(0-62)$ \\
\hline Sleeping problems & $1(0-83)$ & $1(0-83)$ & $0(0-57)$ \\
\hline Sum rest & $18(0-164)$ & $63(0-314)$ & $28(0-233)$ \\
\hline
\end{tabular}

+ VAS = visual analogue scale.

* Measured retrospectively at first follow-up.

PTC $=$ post-traumatic complaints. 
Table 3.Correlations (Spearmann Rho) for severity of post-traumatic complaints after 6 months in four subgroups.

\begin{tabular}{llll}
\hline Sum of VAS-score of: & Cognitive PTC & Vegetative PTC & Diysthymic PTC \\
Vegetative PTC & $R=0.68^{*}$ & & \\
Dysthymic PTC & $\mathbb{R}=0.75^{*}$ & $R=0.75^{*}$ & \\
Physical PrC & $R=0.67^{*}$ & $R=0.72^{*}$ & $R=0.72^{*}$ \\
\hline
\end{tabular}

* Correlation is significant at the of level (2-tailled).

$\mathrm{PTC}=$ post-traumatic complaints.

Table 4A. Associations between post-traumatic complaints (summed in subgroups) after 6 months and predictors at the emergency room.

Acute parameters Subgroups of postwtraumatic complaints ${ }^{\#}$ after six months $\exp B^{*}(95 \%$ confint $)$

\begin{tabular}{lllll} 
& Cognitive & Vegetative & Dystim & Physical \\
\hline Dizziness & $3.8(1.1-12.8)^{*}$ & $2.6(0.8-8.0)$ & $3.3(0.9-12.1)$ & $3.2(0.9-11.5)$ \\
Headache & $2.1(0.9-5.2)$ & $2.9(1.3-6.5)^{*}$ & $3.1(1.2-7.9)^{*}$ & $3.2(1.3-16.0)^{*}$ \\
Nausea & $2.1(0.8-5.6)$ & $2.0(0.8-5.0)$ & $3.7(1.3-10.1)^{*}$ & $3.9(1.4-10.5)^{*}$ \\
Vomiting & $0.9(0.2-5.3)$ & $0.5(0.1-2.4)$ & $1.7(0.3-11.4)$ & $4.3(0.7-26.8)$ \\
Neckpain & $0.9(0.3-3.1)$ & $1.5(0.5-4.8)$ & $1.0(0.3-3.76)$ & $0.8(0.2-2.9)$ \\
Elevated 5-100 & $2.0(0.8-5.0)$ & $1.2(0.5-2.8)$ & $1.4(0.5-3.7)$ & $1.5(0.6-4.0)$ \\
Elevated NSE & $1.6(0.5-4.9)$ & $2.0(0.8-5.5)$ & $1.3(0.4-4.2)$ & $1.4(0.5-4.5)$ \\
\hline
\end{tabular}

\# sum of VAS scores in differen PTC subgroups.

$\$ B$ - Coefficients from linear regression analysis of in outcome variable (severify of post-tratumatic complaints after six months) on acute parameters after adjustment for gender, age and advised bed rest after trauma.

wp<0.05 (two-sided test).

patients. NSE concentrations wete elevated in $40 \%$ of patients, while S-100B concentrations were elevated in $38 \%$ of patients.

Ontcome variables. VAS scones of PTC after two weeks and six months are smmmatized in rable 2. Forgetfulness, drowsiness, headache, dizziness, trouble concentrating and lightheadedness were the severest complaints after two weeks. After six months, the severicy of most complaints had declined to pre-tramma levels. though medians for headache, dizziness and drowsiness were still increased. 
Table 4B. Associations between five specific post-raumatic complaints after 6 months and predictors at the acute moment.

\begin{tabular}{|c|c|c|c|c|c|}
\hline \multirow[t]{2}{*}{ Aculo parameters } & \multicolumn{5}{|c|}{ 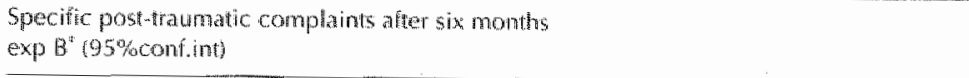 } \\
\hline & $\begin{array}{l}\text { Trouble } \\
\text { concentabing }\end{array}$ & Forgetful & Dizziness & Headache & Drowsiness \\
\hline Dizziness & $3.5(1.2-10.3)^{*}$ & $2.6(0.9-7.1)$ & $1.5(0.5-4,3)$ & $2.4(0.9-6.4)$ & $3.8(1.3-11.3)^{\mathrm{at}}$ \\
\hline Headinche & $29(1.3-6.2)^{*}$ & $1.2(0.6-2.5)$ & $37(1.9-6 \%$ & $1.90 .9-3.9)$ & $2.4(1.11 .5 .4)^{2}$ \\
\hline Nusea & $2.6(1.1 .6 .3)^{4}$ & $1.3(0.6-3.0)$ & $3.1(1.4-6.8)^{*}$ & $2.811 .3 \times 6.1)^{4}$ & $3.7(1.3-10.1)^{k}$ \\
\hline Utowomitang & $0.8(0.2-4.1)$ & $0.8(0.2-3.5)$ & $6.8(1,6.29 .0)^{*}$ & $1.6(0.4-6.6)$ & 1.80 .49 .09 \\
\hline Neck pain & $0.2(0.3-2.6)$ & $1.1(0.4-3.2)$ & $0.6(0.2-1.63)$ & $0.8(0.3-0.9)$ & $10)(0.3-3.3)$ \\
\hline Elevated $5-100$ & $1.2(0.5-2.8)$ & $2.2(1.04 .9)^{*}$ & $1.2(0.5-2.6)$ & 1.240 .62 .59 & $1.0(0.4 .2 .5)$ \\
\hline Hewaled NSE & $0.5(0.6-4.0)$ & $1.3(0.5-3.2)$ & $2.3(0.9-5.6)$ & $2.2(1,0.5,0)^{*}$ & $1.2(0.4-3.3)$ \\
\hline
\end{tabular}

\# Sum of VAS scores in different PTC subgroups.

$\$ B=$ Coefficients from linear regression analysis of In outcome variable (severity of post-traumatic complaints after six months) on acute parameters after adjustment for gender, age and advised bed rest affer trauma.

p $<0.05$ (two-sided test).

Table 5. Presence of symptoms at the $\mathbb{E R}$ as a diagnostic test for the presence of post-iraumatic complaints 6 months alter a mild traumatic brain injury.

\begin{tabular}{llll}
$\begin{array}{l}\text { Number of symptoms } \\
\text { at the ER }\end{array}$ & $\begin{array}{l}\text { Presence of PTC } \\
(n=22)\end{array}$ & $\begin{array}{l}\text { Absence of PTC } \\
(n=57)\end{array}$ & $\begin{array}{l}\text { Prevalence of full } \\
\text { recovery }\end{array}$ \\
\cline { 2 - 4 } $3(n=8)$ & 4 & 4 & $50 \%$ \\
$2(n=13)$ & 5 & 8 & $62 \%$ \\
$1(n=31)$ & 7 & 24 & $77 \%$ \\
$0(n=27)$ & 6 & 21 & $78 \%$ \\
\hline
\end{tabular}

* Headache, dizziness and nausea.

Strong correlations were found between the sum scores of all PTC subgroups after six months (table 3).

Associations betureen acute symptoms and outcome vaviables. After adjustmont for gender, age and advised bed rest, linear regression analysis of lin sum VAS scores of the four PTC subgroups after six months showed an at least twofold increased sum VAS score for all PTC subgroups in those patients reporting headache, dizziness and/or nausea at the ER (table 4A). Twofold increased "cognitive' and "vege- 
tative' sum VAS scores were found in those with, respectively, elevated S-100B and NSE concentrations.

For patients reporting headache, dizziness or nausea at the ER, linear regression analysis of In VAS scores for five specific PTC (adjusted for gender, age and advised bed rest) showed an at least twofold increased severity of one or more PTC after six months (table 4B). Vomiting was only associated (sevenfold) with 'dizziness". A twofold increased severity of 'forgetfulness', 'dizziness' or 'headache' after six months was found in those patients with elevated early serum NSE or $\mathrm{S}-100 \mathrm{~B}$ concentrations. No correlation was found between neck pain at the ER and outcome after six months.

Clinical tests to predict outcome. Twenty-two of 79 patients (28\%) were classified as "not fully recovered" after six months. We tested the clinical value of headache, dizziness and nausea at the ER in predicting full recovery after six months. Vomiting was not included because only $6 \%$ of the patients suffered this symptom. The prevalence of full recovery increased from $50 \%$ to $78 \%$ as the number of symptoms at the ER decreased from three to zero (table 5). When we included serum markers of 68 patients as additional variables, full recovery was predicted in all 10 patients with no symptoms and nomal serum markers.

\section{DISCUSSION}

According to the criteria used in the present study, $28 \%$ of patients suffered from one or more PTC six months after MTBI. Using the same set of PTC, Bohnen reported that symptoms in $25 \%$ of patients persisted for up to six months (18). Other studies found that $20 \%$ - $80 \%$ of patients with MTBI did not recover completely within the first year after the trauma $(2,4,7)$. This huge variation probably reflects the different definitions of MTBI and the use of different outcome variables in these studies. Cut-off points for the Glasgow Coma Score used to define MTBI ranged from 13-15. Outcome variables used included post-traumatic complaints and/or neuro-psychological test results.

In the present study, MTBI was defined on the basis of the most recent literature $(6,20,21)$. The outcome variables in the present study were virtually the same as those used by Bollnen and the Oxford Head Injury Service $(5,18,19)$. 
Even though there was a strong association between the seventy of PTC in the different subgroups, physical complaints scored highest. The finding that headache and dizziness are important specific PTC confirms the findings of previous studies $(4,7,9,22,23)$. Patients in the present study reported only marginally more 'forgetfulness' and 'trouble concentrating' after six months than the reported pre-traumatic levels. These specific variables, however, were included in the analysis because they had been mentioned as important outcome variables in. earlier studies $(9,22,24,25)$.

It was shown that the presence of headache, nausea and dizziness in MTBI patients at the ER is associated with the severity of PTC after six months. Though the presence of headache within 24 hours after the trama has previously been described as a prognostic factor for outcome after MTBI $(2,7)$, the relation with nausea and dizziness had not been reported before.

Vomiting was only associated with the subgroup of physical PTC. This seems to be mainly due to the strong association with dizziness. In the literature, a twofold increased risk of skull fractures has been reported for post-trammatic vomiting (26). However, no association between vomiting and severity of PTC has been described before. In our study, the relationship becween vomiting at the ER and dizziness after six months might be explained by the occurrence of peripheral vestibular injury (labyrinthal contusion).

Elevated biochemical marker concentrations were only associated with some of the PTC after six months. The fact that $S-100 \mathrm{~B}$ was associated with the severity of cognitive PTC seems to support earlier findings that clevated $\mathrm{S}-100 \mathrm{~B}$ is predictive of poorer cognitive functioning $(16,17)$. Elevated NSE concentritions were positively associated with severity of dizziness and headache after six months. Post-traumatic headache is believed to be mainly muscle related (27). Therefore, the elevated NSE concentrations could originate from damaged muscle tissue.

The presence of neck pain at the $\mathbb{E R}$ was not at all associated with PTC after six months. This finding is notable, since complaints reported after whiplash injuries without MTBI are generally similar to those found in the present study (28).

Although headache, nausea and dizziness were strongly associated with severity of PTC after six months, half of the patients with a combination of these three symptoms at the ER still had PTC after six months, whereas the other half of the patients had fully recovered. The prevalence of full recovery increased further in 
patients reporting two symptoms (62\%) or one symptom (77\%). Patients reporting no symptoms at the ER had a $78 \%$ chance of full recovery. The negative predictive value increased to $100 \%$ when elevated S-100B and NSE concentrations were added to the selection variables. All MTBI patients without elevated serum markers or symptoms at the ER were free of PTC after six months. Allhough biochemical marker data of 11 patients was missing, this seemed not to explain this finding because slightly more patients in the "markers missing' group than in the 'markers not missing' group recovered fully $(81 \%$ and $64 \%$, respectively).

\section{CONCLUSION}

The presence of headache, dizziness and/or nausea at the ER after MTBI is strongly associated with the severity of most PTC after six months. The absence of these symptoms in combination with normal serum marker concentrations within six hours after the trauma seems highly predictive of full recovery after six months. Identifying MTBI patients at the ER without headache, dizziness, nausea and elevated serum marker concentrations may be a promising strategy to reduce unnecessary follow-up. However, these results should be verified in future studies.

\section{REFERENCES}

1. Kras J, McArthur D. Silveman T, Jayaraman M. Epidemiology of Brain Injury. In: Narayan R, Wilberger J, Powlishock ], editors. Netrotmuma. New York: Mc Graw-Hill; 1996. $13-30$.

2. Thomhill S, Teasdale G, Murray G, MeEwen J, Roy C. Penny K. Disability in young people and adults one year after head injury: prospective cohort study. BMI $2000 ; 3200250): 1631-35$.

3. Meerhoff $S$, Kruijk de J, Rutten J. Letfers P, Twijnstra A. De incidentie van traumatisch schedel-w of hersentetsel in het adherenciegebied van het Acadennsch Ziekernuis Mastricht in 1997. Ned Tijdschr Geneesk 2000; 144(40):915-23.

4. Naalt van der I. Zonneren A. Sluter W, Minderhoud J. One year outcome in mild and moderate head injury: the predicive walue of acute injury characteristics related to complaints and retum to work. I Neurol Neurostrg Psychiatry 1999;66:207-213. 
5. King S. Emotional, neuropsychological, and organic factors:

their use in the prediction of persisting postconcussion symptoms after noderate and mild head injuries. J Neurol Neurostrg Psychiatry 1996,61:75-81.

6. Alexander M. Mild tratumatic bran injury: Pathophysiology, natural history, and clinical management. Neurology 1995;45:1253-1260.

7. Rutherford $W$. Postconcussion symptoms: relationship to acute neurological indices, individual differences, and circumstances of injury. In: Mild Head Injury. New York: Oxford University Press; $1989 . p, 217-240$.

8. Paniak C, Toller Lobe $G$, Reynolds S, Melnyk A, Nagy J. A randomized trial of two treatments for mild traumatic brain injury: 1 year follow-up. Brain Inj 2000;14(3):219-26.

9. Wade D, King N, Wenden F, Crawford S, Caldwel F. Routine follow up after head ingury: a second randomised trial. J Neurol Neurosurg Psychiatry 1998;65:177-183.

10. Minderhoud J, Boelens M, Huizinga J, Sam R. Treatment of minor head injuries. Cin Neurol Neurosurg 1980;82:127-140.

11. Hanlon RE, Demery JA, Martinowich Z, Kelly JP. Effects of acute injury characteristics on neurophysical status and vocational outcome following mild tramatic brain injury. Brain Inj 1999; 13(11):873-87.

12. Woertgen $\mathrm{C}$, Rothoerl D, Holaschuh M, Metz $\mathrm{C}$, Brawanski $\mathrm{A}$. Comparison of Serial S-100 and NSE serum measurements after severe head injury. Acta Netrochir $1997 ; 139: 1161-1165$.

13. Raabe A, Menon D, Gupta S, Czosryka M, Pickard J. Jugular venous and arkerial concentrations of serum $S-100 B$ protein in patients with severe head injury: a pilot study. J Neurol Neurosurg Psychiatry 1998; 65:930-932.

14. Ingebrigtsen T, Romner B, Trumpy J. Management of minor head injury: the value of early computed tomography and serum protein $S-100$ measurements. I Clin Neurosc $1997: 4(1): 29-33$.

15. Kruik de J, Leffers P, Menheere P, MeerhofS, "Twijnstra A, S-100B and neuron-specific

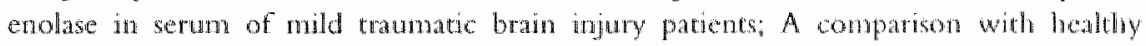
controls. Acta Neurol Scand 2001;103(3):175-179.

16. Hermano M, Curio N, Grubici C, Ebert A. Fork M, Synowitz H. Rellesse of biochencal markers of damage to neuromal and ghal brain tissue is associated with short and long tom neuropsychological outcome after tratuatic brain injury. I Neurol Neurostrig laychiatry $2001770.95-100$.

17. Ingebrigtsen $\mathrm{T}$, Waterloo K, Jacobsen $\mathbf{E}$, Langbakk B, Ronmer B. Traumatic brain damage in minor head injury: relation of serum $S-100$ protein measurements to magnetic resonance maging and nemrobehavorial outcome. Neurosurgery 1999;45(3):468.75.

18. Bohnen $N$, Wijnen $G$, Twijrustra $A$, van Zutphen $W$, Jolles J. The consteilation of late post-traunatic symptoms of mild head injury patients. J Neurol thethab 1995:9(1):33-39.

19. Crawford $S$, Wenden F, Wade D. The Rivernaid head injury follow-up questionmatra a study of a new rating scale and other measures to evaluate outcome after head injury. I Neurol Neurosurg Psychiatry 1996,60:510-514.

20. Nell V, Yates DW. Kruger J. An extended Glasgow Coma Scale (GCS-E) with enhanced sensitivity to mild brain injury, Arch Phys Med Rehabil 2000;81(5)614-7. 
21. Ruff RM, Jurica $P$. In search of a unified definition for mild traumatic brain injury. Brain Inj $1999,13(12): 943-52$.

22. Evans RW. The postconcussion syndrome and the sequelate of mild head injury. Neurol Clin $1992 ; 10(4): 815-47$.

23. Packard $k_{*}$ Ham L. Postramatic headache. I Neuropsychiatry Clin Neurosc $1994 ; 6: 229-236$.

24. Harrington D, Malec J. Cicerone $\mathrm{K}, \mathrm{Kat} \mathrm{H}$. Current perceptions of rehabilitation profes sionals towards mild tratmatic brain injury. Arch Phys Med Rehabil 1993;74:579-586.

25. Natal wan der J, Joffre $M$, Zomeren van A, Sluiter W, Minderhoud J. Computed Tomography and Magnetic Resonance Imaging in mild to moderate head injury: Early and late imaging related to outcome. Ann Neurol 1999;46(1);70-77.

26. Nee P, Hadfield J, Yates D, Faragher E. Significance of vomiting after head injury. I Neurol Neurosurg Psychiatry $1999 ; 66: 470-473$.

27. Packard R. Epidemiology and pathogenesis of postmeramatic headache. I Head Tramma Rehabil 1999; 14(11):9-21.

28. Alexander M. In the pursuit of proof of brain injury damage after whiplash injury. Neurology $1998 ; 51: 336-340$. 
CHAPTER

\section{dint?}

GENERIC HEALTH STATUS FOLLOWING MILD TRAUMATIC BRAIN INJURY 


\section{INTRODUCTION}

Most cases of traumatic brain injury belong to the category of mild raumatic brain injury (MTBD). Beside rare acute intracranial complications and early complaints, the health status of MTBI patients is mostly detemined by persistent post-traumatic complaints (PTC). Although it is believed that damage to the brain following MTBL can be demonstrated by neuro-imaging and biochemical serum markers, $(1,2)$ it is not clear to what extent these complaints are directly caused by brain injury or are rather the result of the trauma experience in combination with psychosomatic, emotional or motivational factors.

During the last decade, many disciplines have been involved in the evaluation of outcome after MTBI. Most studies have evaluated PTC (3-8) or neuro-psychological test results. (5, 8-10) MTBI may represent a 'hidden disability', as a person nay seem physically normal, yet have considerable PTC. Information about the negative effect on daily life activities may complement reported PTC in assessing the consequences of MTBI.

Few studies have measured generic health status m MTBI patients. The 36-item short form health survey questionnaire $(\mathrm{SF}-36)$ is a widely used generic health status measure. Recently, Paniak et al. found that the SF-36 questionmaire is a sensitive measure of MTBI-related general health effects three weeks after the trauma. (11). The long-term consequences for generic health status have not yet been assessed in MTBI patients. The aims of the present study were: 1) to investigate the generic thealth status of MTBI patients two weeks, three months and six months after the trauma; 2) to describe the association between the presence of post-traumatic complaints and generic health status six months after the event.

\section{METHODS}

Participants. The present study was part of an intervention study on the efficacy of bed rest for MTBI patients. The study was approved by the institutional ethics committee of the Maastricht Universicy Hospital. All patients provided written informed consent.

MTBI patients were eligible for the study if they were older than fiften years and presented at the emergency department within six hours after the rauma. Dura- 
tion of post-tratumatic amnesia (PTA) and presence of transient loss of consciousness (LOC) were estimated on the basis of information from the patient and/or witnesses. MTBI was defined as a blunt blow to the head resulting in 1) PTA of less than 1 hour and/or 2) initial LOC of less than 15 minutes; 3) a Glasgow Coma Score of 14 or 15 on presentation at the emergency department and 4) absence of focal neurological signs. Patients were excluded if they suffered from multiple trauma or if they needed clinical observation. Patients with a history of traumatic brain injury, alcohol abuse or a psychiatric disorder were also excluded.

Outcome wariables. The primary outcome variables were generic health status after two weeks, three months and six month. These were measured by means of the Medical Outcome Study 36-ltem Short-Form Health Survey, which is recognized as a standard generic measure of physical and mental components of health status.(1.2) Based on a multidimensional model of health, the SF-36 is a multi-item self-rating scale that assesses eight health concepts, with a single question addressing change in health status. The eight health concepts can be divided into a physical, a mental and a mixed health dimension (table 1). (12) The present study used the Dutch language version of the SF-36.(13).

The selection of PTC was based on an earlier study, which showed that these complaints differed in severity from those in control subjects. (7) They were measured on wisual analog scales (VAS). At first follow-up, two weeks after the trauma, patients were also asked about the severity of these complaints before the trauma.

Study design. If patients met all admissibility criteria, written and oral explanations about the trial were given by the attending neurologist. A consent form was signed by both patient and physician before the patient was enrolled. Gender and age of the patient and cause of the accident were recorded at first examination. At discharge from the emergency department, the routine home observation instructions (to detect possible intracranial complications in the first 24 hours following the injury) were given to an accompanying person. At the follow-up visits to the outpatient clinic, patients' educational level was recorded and patients filled in questionnaires assessing the outcome variables.

Data analysis. Baseline data including age and gender and causes of injury were described. Raw scores on the SF-36 were transformed to scaled scores ranging from 0 to 100 , with higher scores reflecting better health or less impact on functioning. Scores on the eight dimensions of the SF-36 were subdivided into a 


\section{Generic health status 93}

Table 1. The 36-item Short-Form Health Survey Questionnaire (SF-36).

\begin{tabular}{lcl}
\hline Health concept & Items, $n$ & Dimension \\
\hline Physical functioning & 10 & Physical \\
Role functioning-physical & 4 & Physical \\
Bodily pain & 2 & Physical \\
Role functioning-emotional & 3 & Mental \\
Mental health & 5 & Mental \\
Social functioning & 2 & Mixed \\
Vitality & 4 & Mixed \\
General health perception & 5 & Mixed \\
\hline
\end{tabular}

Table 2. Baseline data including demographics and cause of accident.

Factors known at first presentation after MTB! $(n=103)$

Individual factors

Gender

Female

$43 \%$

Age in years

(mean 37.2; 15-75)

15-25

$28 \%$

26-35

$20 \%$

$36-45$

$20 \%$

$46-55$

$16 \%$

$56-65$

$9 \%$

$>65$

$7 \%$

Education

Low

$35 \%$

Middle

$34 \%$

High

$25 \%$

Special or unknown

$6 \%$

Cause of accident

Traffic

$49 \%$

in/around the house

$18 \%$

Work

$12 \%$

Sports

$9 \%$

Assault

$9 \%$

Other

$3 \%$ 
physical dimension ("Physical functioning', 'Role-functioning physical' and 'Bodily pain') and a mental dimension (Mental health' and 'Role-functioning emotional'). The 'Social functioning', 'Vitality' and 'General health perception' sub-scores were classified as mixed dimension. The mean SF-36 sub-scores two weeks after the trauma were described. The means of the SF-36 sub-scores after three months were compared with the scores after two weeks, using the T-test for paired samples. The same was done for the scores at six months compared to those at three months. Medians and 5 and 95 percentiles of VAS scores for all PTC after six months were recorded. Patients were divided into a group 'with PTC' and a group 'without PTC' after six months. Patients were considered to be "without PTC" if the VAS scores of all PTC after six months were lower than the 95 percentile of the pre-traumatic VAS scores retrospectively measured at the first follow-up moment. If one or more VAS scores after six months were higher than the pre-traumatic 95 percentile, the outcome was defined as 'with PTC'. The mean SF-36 sub-scores at six months in the 'without PTC' and 'with PTC' groups were compared using non-parametric Mann-Whitney U tests.

\section{RESULTS}

Between October 1996 and June 1999, 107 MTBI patients were enrolled in the study. After two weeks, 103 patients showed up for follow-up examination $(96 \%)$, versus $86(80 \%)$ after three months and $79(74 \%)$ after six months. Baseline variables were described for the 103 patients showing up after two weeks (table 2). The SF-36 sub-scores in the course of six months after the trauma, divided into 'physical', 'mental' and 'mixed' dimensions, are shown in fig. 1. Improvements in sub-scores of physical dimensions were statistically significant between two weeks and three months, while sub-scores of mental dimensions did not alter much between these follow-up moments (toble 3). In contrast, the improvement in the mental sub-score of 'Role-functioning emotional' between three and six months was statistically significant. Although statistically significant, 'Role-functioning physical' and 'Social-functioning' improved less between three and six months than between two weeks and three months. "General health perception' not change in the course of six months. 

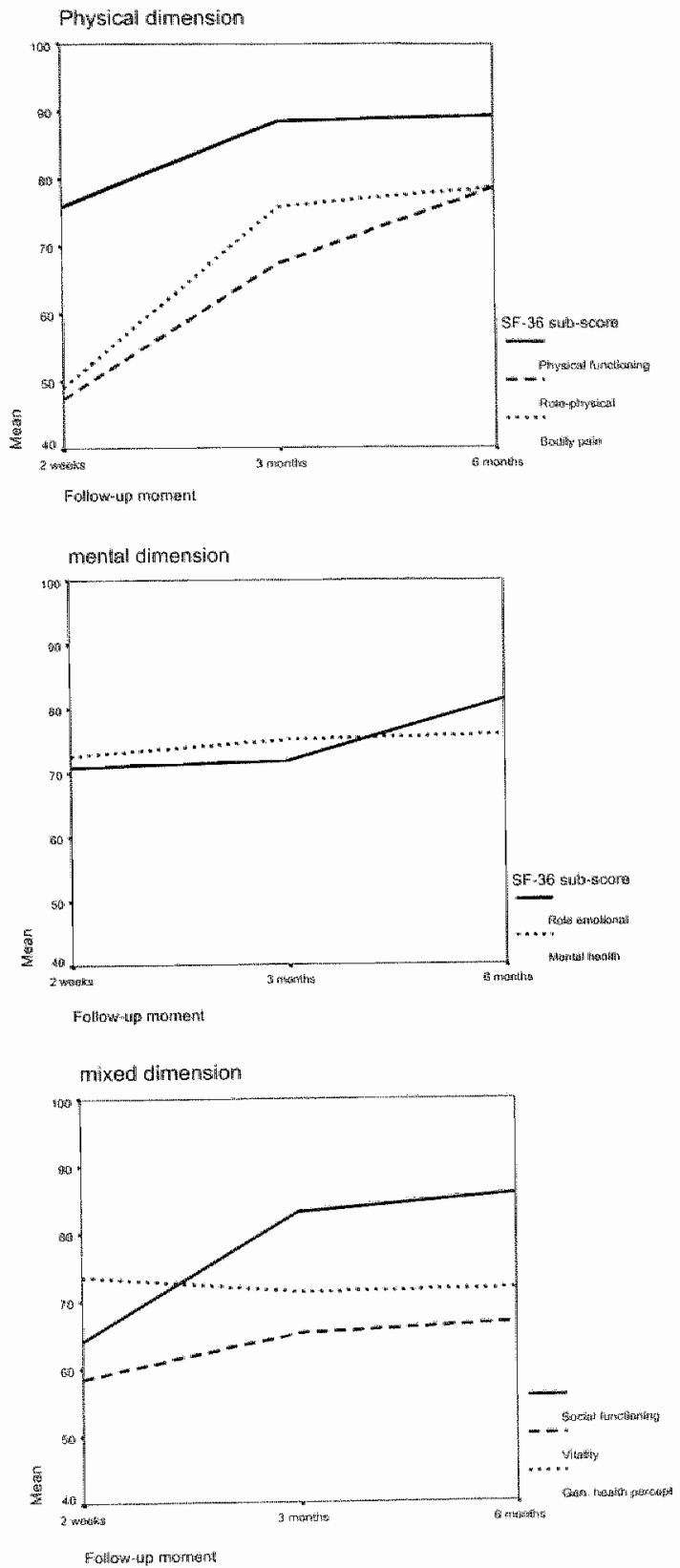

Fig 1. SF-36 sub-scores in the course of six months after a mild traumatic brain injury. 

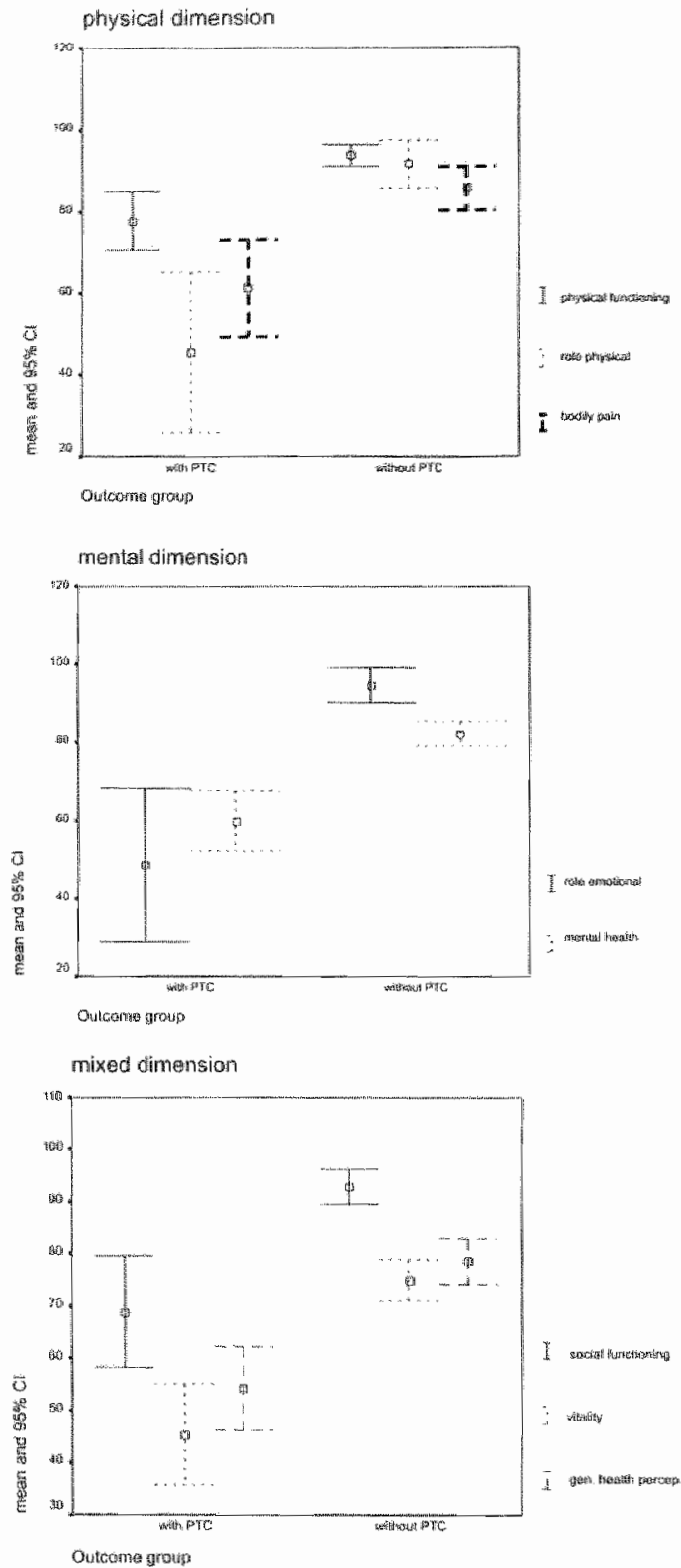

Fig 2. SF-36 sub-scones six months after a mild traumatic brain infury in patients with and without post-traumatic complaints. 
Table 3. SF-36 sub-scores at three different follow-up moments after a mild traumatic brain injury.

\begin{tabular}{|c|c|c|c|}
\hline \multirow[t]{2}{*}{$5 F-36$ scores (mean) } & \multicolumn{3}{|c|}{ Follow-up moment } \\
\hline & $\begin{array}{l}2 \text { meeks }(n=103) \\
\text { T1 }\end{array}$ & $\begin{array}{l}3 \text { months }(\mathrm{m}=86) \\
\mathrm{T} 2-\mathrm{T} 1(95 \% \mathrm{Cl})^{5}\end{array}$ & $\begin{array}{l}6 \text { months }(\mathrm{n}=79) \\
13-12(95 \% \mathrm{c})\end{array}$ \\
\hline Physical functioning & 76 & $14(10-16)$ & $1(-2-4)$ \\
\hline Role (physical) & 47 & $23(11-34)$ & $13(5-20)$ \\
\hline Bodily pain & 49 & $28(22-34)$ & $5(0-9)$ \\
\hline Role (emotional) & 76 & $2(-7-11)$ & $12(4-20)$ \\
\hline Mental health & 73 & $2(-2-7)$ & $2(-1-5)$ \\
\hline Social functioning & 64 & $21(14-27)$ & $4(1-7)$ \\
\hline Vitality & 59 & $8(3-13)$ & $2(-1-5)$ \\
\hline General health & 74 & $-2(-6-2)$ & $1(-3-4)$ \\
\hline
\end{tabular}

* Raw scores on the SF-36 were transforned to scaled scores ranging from 0 to 100 , with higher scores reflecting better health or less impact on functioning.

$\S=$ mean increase $(95 \%$ Confidence Intervals) in SF36 sub-scores in comparison with scores at previous follow-up (paired sample T-test).

VAS-scores of PTC after six months and pre-traumatic VAS-scores are summarised in table 4. Twenty-two of 79 patients (28\%) were classified as 'with PTC' after six months. SF-36 sub-scores in patients with and without PTC after six months are presented in fig2. All mean SF-36 sub-scores in patients with PTC were significantly higher than in those without PTC (Mann Whitney $\mathrm{U} ; \mathrm{p}<$ $0.0001)$ 
Table 4. Severity of post-traumatic complaints six months after a mild traumatic brain iniury.

\begin{tabular}{|c|c|c|}
\hline \multirow{2}{*}{$\begin{array}{l}\text { VAS }{ }^{*} \text { score of } \\
\text { post-tramatic complaints }\end{array}$} & \multicolumn{2}{|l|}{ Follow-ap moment } \\
\hline & $\begin{array}{l}\text { Before trauma } \\
\text { median ( } 5-95 \text { percentile) }\end{array}$ & $\begin{array}{l}\text { Six months }(n=79) \\
\text { median }(5-95 \text { percentile })\end{array}$ \\
\hline Trouble concentrating & $0(0-50)$ & $1(0-80)$ \\
\hline Easily overwhelmed by problems & $0(0-45)$ & $0(0-66)$ \\
\hline Forgetful & $1(0-45)$ & $1(0-70)$ \\
\hline Flushing easily & $0(0.53)$ & $0(0-20)$ \\
\hline Feeling short of breath & $0(0.55)$ & $0(0-52)$ \\
\hline Feeting faint & $0(0-59)$ & $0(0-53)$ \\
\hline Depressed & $0(0-48)$ & $1(0.59)$ \\
\hline Drowsy & $0(0-43)$ & $3(0-90)$ \\
\hline Crying more easily & $0(0-41)$ & $0(0-19)$ \\
\hline Confused & $0(0-22)$ & $0(0-49)$ \\
\hline Headache & $1(0-59)$ & $3(0-75)$ \\
\hline Dizziness & $0(0-32)$ & $3(0-60)$ \\
\hline Nausea & $0(0-14)$ & $0(0-26)$ \\
\hline Light-headed & $0(0-33)$ & $1(0-60)$ \\
\hline Paresthesia of amm(s) & $0(0-29)$ & $1(0-62)$ \\
\hline Sleeping problems & $1(0-83)$ & $0(0-57)$ \\
\hline
\end{tabular}

\# VAS = visual analogue scale.

* measuned retrospectively at first follow-up.

\section{DISCUSSION}

The present study is the first in which generic health status was followed over a period of six months after MTBI using the SF-36 Health Survey Questionnaire. Our results confirm Paniaks' finding that generic health status is impaired after MTBI and that physical health dimensions and social functioning are more affected than mental health dimensions. The physical health dimension improved mainly between two weeks and three months, whereas improvement of the mental health dimension chiefly occurred between three and six months after the trauma. Because no non-trauma reference group was used in the present study, the results of our study do not show directly whether generic health status is still 

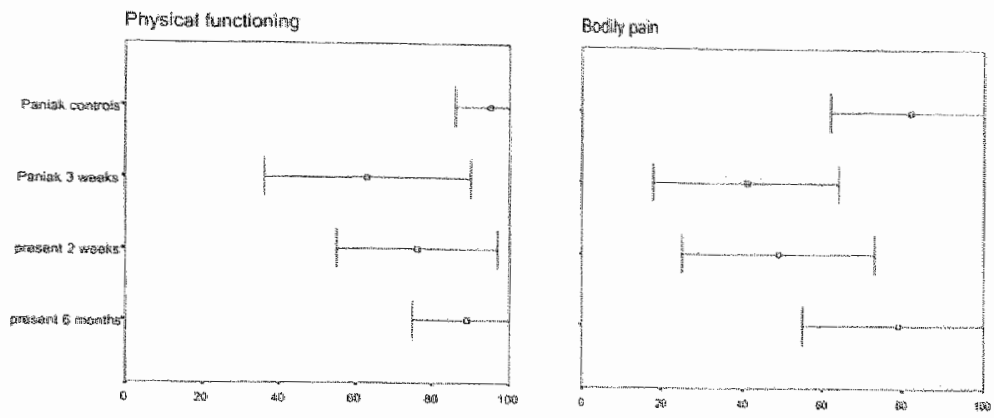

Role Physilcat

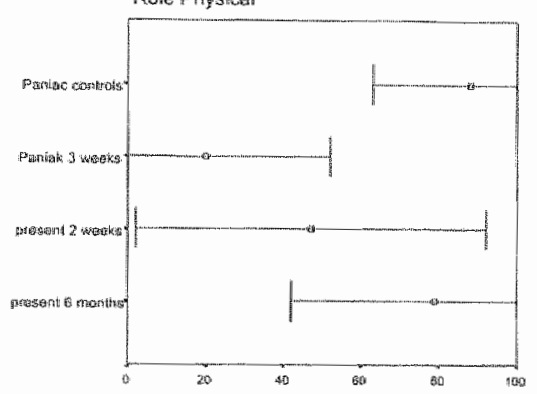

Rolo exhmidion
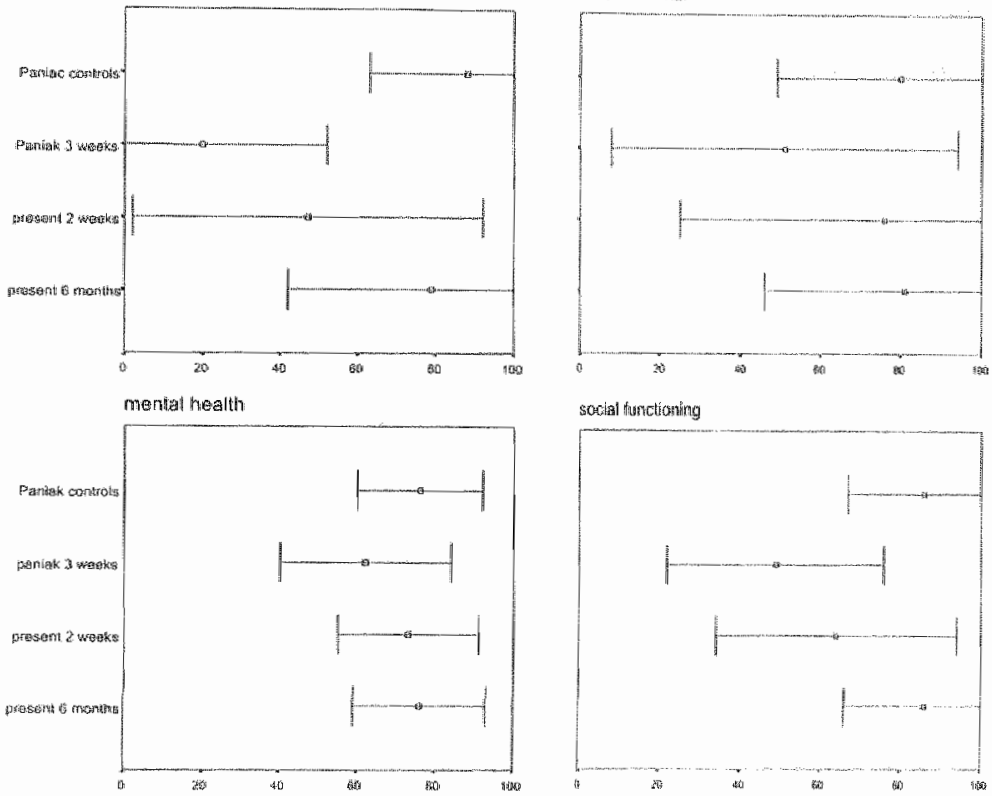

sorial filsectioning
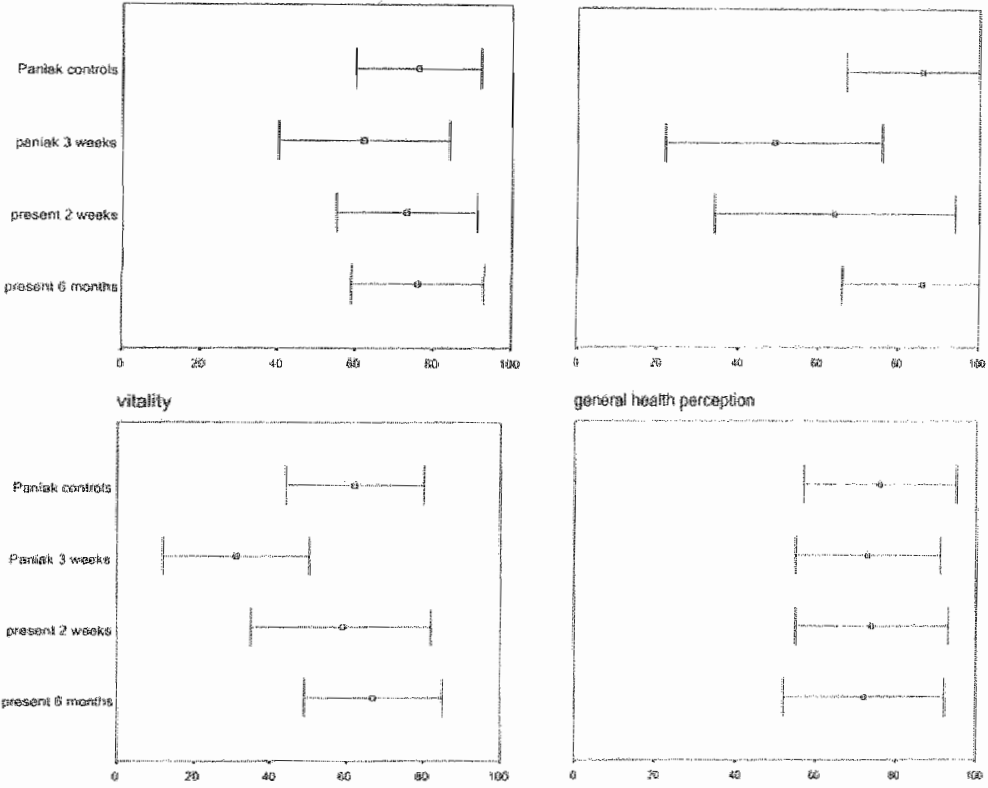

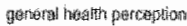

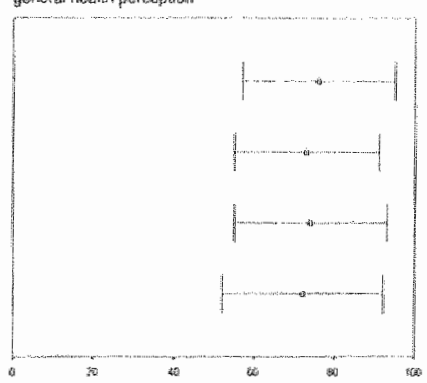

Fig 3. SF-36 sub-scores at various follow-up moments in Paniaks study and our study. 
affected six months after the trama. However, six months after the trauma, patients in the present study had scores similar to those of the healthy controls in Paniaks" study on all SF-36 dimensions (fig 3).(11) Apart from 120 healthy subjects, Paniak evaluated SF-36 scores in 120 patients, three weeks after MTBI (GCS $13-15$ and PTA $<24$ hours). In our study, patients scored slightly better on all SF-36 sub-scores two weeks after the trauma than the patients in Paniaks" study did three weeks after MTBI (fig 3 ). This difference could be the result of the stricter MTBI definition used in our study (PTA $<1$ hour). The scores on the sub-item "General health perception" after two weeks and six month in the present study were similar to scores found by Paniak et al. in controls and in MTBI patients after three weeks. This finding confirms Paniaks" finding that even shortly after injury most MTBI patients reported good overall health. However, we also found that the small group of patients with PTCs six months after the trauma had poorer scores for 'General health perception', and all other $S F-36$ sub-items, than patients without PTC.

We conclude that most MTBI patients have a normal generic health status after six months. However, patients with PTC after six months have a clearly impaired generic health status at that moment. The 36-item Short Form Health Survey Questionnaire SF-36 seems a useful additional test to estimate the influence of MTBI on daily life activities for clinical trials evaluating outcome after MTBI.

\section{REFERENCES}

1. Hofman P" Stapert S, van Kroonenbugh M, Jolles J, de Kruijk J, Wilnink J. MR innaing. Singlem Photon Ennission CT, and neurocognitive performance after mild traumatic bran injury. An J Newrondiol 2001,22:441-449.

2. Kruijk de J, Lefers P. Menhoere P. MeenofTS, Twijnstra A. S-looB and neuton-specific enolase in serum of mild tramatic brain imjury patients; A comparison with healthy controls. Acta Netrol Scand 2001;103(3):175-179.

3. Thombill $S$. Teasdale $G$ Murray $G$, McEwen J, Roy $C$, Penny K. Disability in young people and adults one year after head injury: prospective cohort study. BMJ $2000,320(7250): 1631-35$.

4. Naxlt vam der J, Zomeren A, Sluiter W, Minderhoud $\mathbb{J}$. One year outcome in mild and modkrare head injury: the predictive value of acute injury characteristics related to complaints and retum to work. I Neurol Nemrosurg Psychiary 1999;66:207-213. 
5. Deb S, Lyons I, Koutzonkis C. Netropsychianic sequelae one year after an mor head injury. J Neurol Newrosurg Psychiatry 1998;65:899-902.

6. Crawfond $\mathrm{S}$, Wenden $\mathrm{F}$, Wade $\mathrm{D}$. The Rivermaid head injury follow-up questionnaire: a study of a new rating scale and other measures to evaluate outcome after head injury. I Neurol Neurosurg Psychiatry $1996,60: 510_{-5} 514$.

7. Bohnen $N$, Wijnen $G$, Twijnstra $A$, van Zutphen W, Jolles J. The constellation of late post-traumatic symptoms of mild head injury patients. J Neurol Rehab 1995;9(1):33-39.

8. Levin $H$, Mattis S, Ruft R, Eisenberg H, Marshall L, Tabaddor K, et al. Neurobehavional outcome following minor head injury: a three-center study. J Neurosurg 1987;66:234-243.

9. Voller B, Benke T, Benedetro K, Schnider P. AuftE, Aichner F. Neuropsychological, MRI and EEG finding after very mild trammatic brain injury. Brain Inj 1999;13(10):821 -7.

10. Newcombe F, Rabbitt P, Briggs M. Minor head injury: pathophysiological or iatrogentc sequelae? J Neurol Neurosurg Psychiatry 1994;57(6):709-16.

11. Paniak $C$, Phillips $K$, Toller-Lobe $G$, Durand $A$, Nagy J. Sensitivity of three recent questionnaires to mild traumatic brain injurymrelated effects. J Head Tramma Rehabil $1999 ; 14(3): 211-19$

12. McHomey $C$, Ware J, Raczek A. The MOS 36-item Short-Form Health Survey (SF-36): If Psychometric and clinical tests of validity in mearumg physical and mental heaith constructs. Med Care 1993;31(3):247-263.

13. Aaronson N, Muller M, Cohen P. Essink-Bot M, Fekkes M, Sanderman R et al Translation, validation, and nomung of the Dutch language version of the $S \mathrm{H}-36 \mathrm{Health}$ Survey in community and chronic disease populations. J Clin Epidemiol 1998;51(11):1055-1068. 


\section{,}




\section{CHAPTER}

\section{EFFECTIVENESS OF BED REST AFTER MILD TRAUMATIC BRAIN INJURY}

A randomised trial of none versus six days of bed rest

Presented at the 53 rd annual meecing of the American Academy of Neurology; 2001; Philadelphia, USA

\section{Adapted from:}

Kruijk de J, Lefers P, Meerhoft S, Rutten J. Twijnstra A. Efficacy of Bed rest after Mild. trammatic Brain Injury: a randomized trial of none versus six days of bed rest. Sthmitued 


\section{ABSTRACT}

Background: Mild traumatic brain injury (MTBI) accounts for most cases of Eraumatic brain rjoury and outcome is largely determined by the appearance of post tratunatic complaints (PTC). The prevalence of PTC after six months is estimated to be between 20 and $80 \%$. Bed rest has been advocated to prevent PTC, but its effectiveness has never been established. The aim of the present study was to evaluate the effect of bed rest on the severity of PTO atter MTBI.

Methods Patients presenting with MTBI at the emergency room were randomised over two intervention strategies. One group was advised not to take bed rest (NO), the other to take full bed rest (FULL) for six days after the tramna. The primary outcome neasures were severity of post-tramatic complaints on a visual analogue scale, and physical health and mental health on the MOS 36-iten short-form health survey (SF-36) at two weeks and three and six montlis after the trauma.

Results: Between October 1996 and July 1999, 107 (54 NO, 53 FULL) patients were included Outcome variables in both groups clearly improved between two weeks and six months. After adjustment for differences in baseline variables, most PTC tended to be somewhat more severe in the FULL groing six months after the trauna but no statistically significant differences were found. Neither were there any statistically significant differences in the outcome parameters between the two groups after three months. Two weeks after the tratma, most PTC in the FULL, group were slightly less severe than in the NO group and physical sub-scores of the SF-36 in the FULL group were slightly better. These differences were not statistically significant. Patients in the FULL group reported significantly less severe dizziness during the intervention period.

Conclusions: As a means of speeding up recovery of patients with PTC after MTBI, bed rest is no nore effective than no bed rest at all. Bed rest probably has sone palliative effect within the first two weeks after the trauma. 


\section{INTRODUCTION}

Mild traumatic brain injury (MTBI) accounts for about $90 \%$ of all traumatic brain injuries. (1-3) In addition to the individual impairments, the burden to society is also large, in terms of hospital costs and production loss resulting from post-traumatic complaints (PTC).

$(4,5)$

Apart from very rare acute intracranial complications, outcome after MTBI is mostly determined by the appearance of PTC. Alehough the severity of most PTC declines during the first three months, $(6,7)$ the prevalence of PTC after six months is estimated at $20-80 \% \cdot(8-11)$ The huge variation in these estimates probably mainly reflects the different definitions of MTBI and PTC used in the various studies. In addition to PTC, both brain and non-brain (eg, musculoskeletal) injuries in MTBI patients negatively affect generic health status during the first year after the trauma.(12)

Education, rehabilitation and drugs have been used with at best limited success in the prevention and treatment of PTC. $(5,13-19)$ The effectiveness of bed rest for preventing PTC has hardly been studied, with only one study seeming to suggest that longer bed rest leads to an increase in PTC.(20) Notwithstanding this uncertainty about the efficacy of bed rest, many European neurologists (40\%) continue to recommend one or more days of full bed rest after MTBI.(21) Doubt has been cast on the effectiveness of bed rest in many situations where it has traditionally been recommended. A recent review of randomised trials on bed rest for 15 other medical conditions concluded that bed rest did not improve the prognosis (for example in uncomplicated myocardial infarction) or even worsened the outcome in some situations (for example in spontaneous labour).(22) We conducted a randomised trial of the effectiveness of six days of bed rest versus no bed rest in terms of the severity of PTC and generic health status after six months.

\section{METHODS}

Participants. The study was approved by the institutional ethics committee of the Maastricht University Hospital and all patients provided written informed consent. 
Patients were eligible for this study if they were older than fifteen years and presented at the emergency department within six hours after the trauma. Duration of post-traumatic amnesia (PTA) and presence of transient loss of consciousness (LOC) were estimated on the basis of information from the patient and/or witnesses. MTBI was defined as a blunt blow to the head resulting in 1) PTA of less than 1 hour and/or 2) initial LOC of less than 15 minutes; 3) a Glasgow Coma Score of 14 or 15 on presentation at the emergency department and 4) absence of focal neurological signs. Patients were excluded if they suffered from multi-trauma or when there was necessity for clinical observation. Patients with a history of traumatic brain injury, alcohol abuse or psychiatric disorder were also excluded.

Intervention. The difference between the strategies compared was the amount of recommended bed rest between 8.00 AM and 8.00 PM during the first week after the trauma. Patients in the no bed rest group (NO) were instructed to mobilise from the first day after the trauma, with at most four hours of bed rest on the first day, three hours on the second day, two hours on the third day and one hour on the fourth day. Patients were expected to resume normall daily activities and/or work on the fifth day. Patients in the full bed rest group (FULL) were instructed to take full bed rest during the first six days following the trauma. Starting from day 7 , patients were advised to follow the same mobilisation schedule given to the NO group. The maximum number of hours of bed rest in the NO group was to be 10, while the patients in the FULL group were expected to rest for between 72 hours and 82 houts.

Outcome variables. The primary outcome variables were the severity of sixteen PTC and generic health status at two weeks, three months and six months after the trauma. The PTC, which were measured on a visual analog scale (VAS), were divided into four subgroups (cognitive, dysthymic, vegetative, and physical) in accordance with an earlier study.(10) Generic health status was measured by means of the MOS 36-item short-form health survey (SF-36); Dutch language version (23) which is recognized as a standard generic measure of physical and mental components of health status. (24)

Study design. If patients fulfilled all admissibility criteria, written and oral explanations about the trial were given by the attending physician (neurology resident). A consent form was signed by the patient and the physician before the patient was emrolled. In order to obtain equal group sizes, randomisation was. 
Bedrestand ourcome $\mid 107$

done in blocks of 2 and 4 . The sequence of block sizes was determined at random.

The gender and age of the patient, the cause of the accident and the presence of headache, nausea, vomiting and dizziness were recorded at first exammation. Traumatic injuries to limbs, trunk or head were also recorded and if necessary, radiological examination was performed. The assigned advice was explained by the physician and it was also clearly summarised on the first page of the medical diary that each patient received. To evaluate their complance, patients were asked to note the daily number of hours of bed rest during the first 10 days following the trauma. This diary also contained questions about the use of analgesics and recorded the severity of headache, dizziness and nausea by means of a VAS. Another VAS was used to let patients score the level of difficulty they experienced in complying with the advice during a particular day. Ar discharge from the emergency department, the routine home observation instructions (to detect possible intracranial complications in the first 24 hours following the injury) were given to an accompanying person. At the follow-up visits to the outpatient clinic, patients filled in questionnaires assessing the outcome variables.

Analysis. Baseline data including age and gender, causes and symptoms of injury were compared between the NO and FULL groups. The total duration of bed rest during the first ten days, the sum of the levels of difficulty experienced in complying with the assigned advice over the first four days and the number of analgesics tablets used over the first four days were calculated and compared between the two groups. The same was done for headache, dizziness and nausea during the first four days of intervention. Raw scores on the SF-36 were transformed to scaled scores ranging from 0 to 100 , with higher scores reflecting better health or less impact on functioning. The median VAS scores of the 16 PTC and the mean SF-36 scores for the various follow-up moments were compared between the NO and FULL groups. Since some of the baseline parameters differed between the two groups, differences in outcome between the two intervention groups were tested by means of multiple linear regression analysis of $\rrbracket_{n}$ VAS scores of post-traumatic complaints and SF- 36 scores on gender, $30 c i a l$ situation and the presence of headache, dizziness and vomiting at the ER. 


\section{RESULTS}

Between October 1996 and June 1999, approximately 1125 patients with MTBI were seen at the University Hospital of Maastricht. (3) One hundred and seven of these patients were enrolled in the study. The rest met the exclusion criteria, refused to be included, or were not asked by the attending specialist to partici-

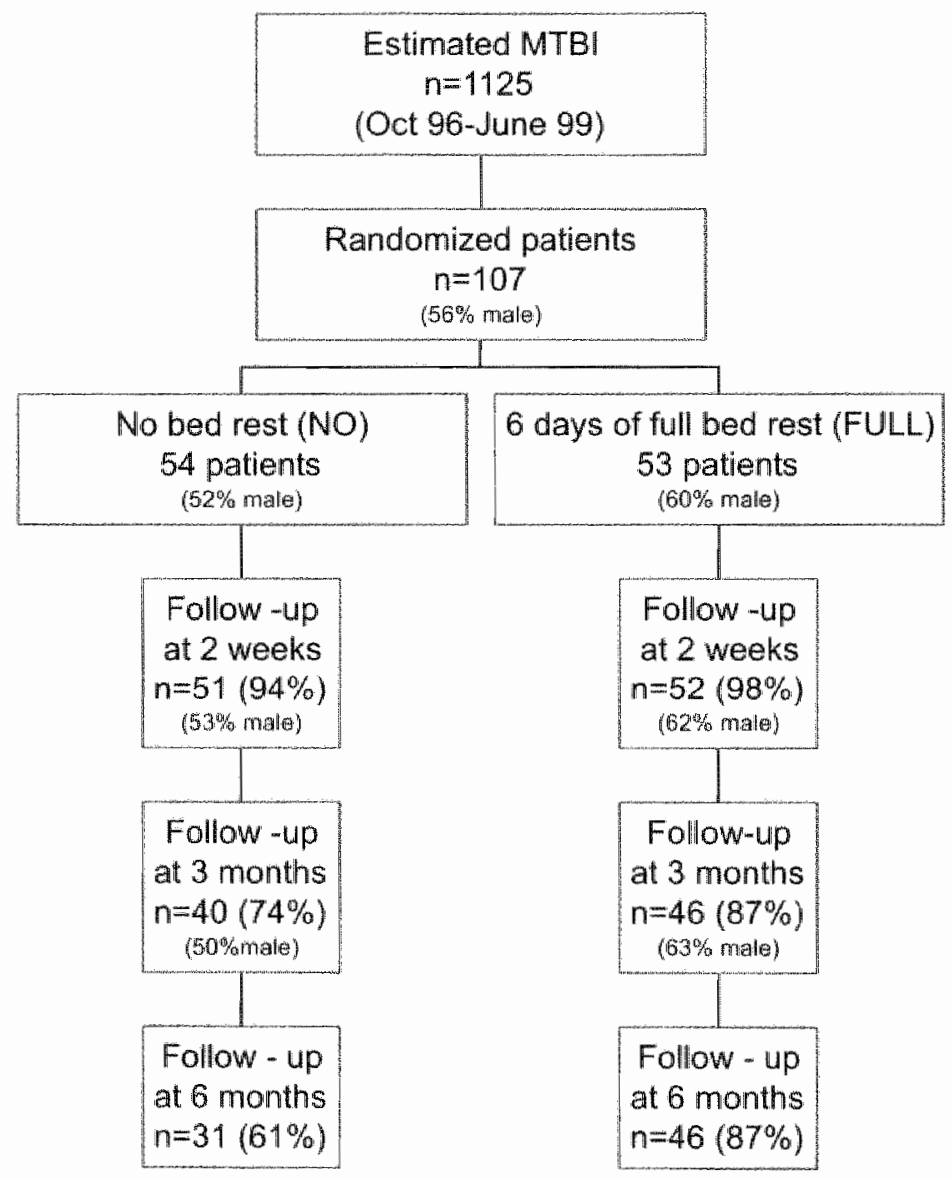

Fig 1. Trial profile. 
pate. Ultimately, 54 patients received the $\mathrm{NO}$ bed rest advice, while 53 received the FULL bed rest advice. Figure 1 shows the flow of the patients in the trial. Four patients were lost to follow-up and nine patients did not fll in their medical diaries during the intervention. After two weeks, $95 \%$ of patients from the NO group and $98 \%$ of those from the FULL group were examined and interviewed. After three months and six months, more patients in the FULL group showed up for follow-up (87\% on both occasions) than in the NO group (74\% and $61 \%$, respectively). The intervention groups were similar with regard to the distributions of age, educational level, cause of the accident, occurrence of LOC and duration of PTA (table 1). The FULL group had relatively more male patients than the $\mathrm{NO}$ group $(60 \%$ vs $52 \%)$ and fewer patients living alone $(36 \%$ vs $50 \%)$. Patients in the FULL group reported some more headache and dizziness in the emergency room before they were randomised, whereas patients included in the NO group vomited more.

Intervention. The mean duration of bed rest in the NO group was 26 hours. After the exclusion of two women who reported 260 and 158 hours of bed rest, the mean for this group became 17 hours (Table 2A). Patients in the FULL group rested for an average of 57 houts during the first ten days after the trauma. Patients in the FULL group found it more difficult to comply with the advice during the first four clays of intervention than those in the $\mathrm{NO}$ group (Table 2A), but this difference was not statistically significant ( $p=0.47$; Mann Whitney $U$ ). Patients in the FULL group used more oral analgesics (median: 3 ) than those in the NO group (median: 1) (table $2 A$ ). This difference was not significant either $(p=0.47$; Mann Whitney $U)$.

During the first four days of the intervention, patients in the FULL group suffered significantly less dizziness than in the NO group (fable 2B). Headache and nausea were also reported slightly (not significantly) less severe in the FULL group after adjustment for differences in baseline variables.

Follow-up. In both intervention groups, severity of PTC diminished and SF-36 scores improved between two weeks and six months after the crauma (tables 3 and 4). After six months, patients in the FULL group reported slightly higher VAS scores on 12 of the 16 PTC after adjustment for bascline differences (rable 3 and fig 2). Only 'headache', 'flushing easily', 'being easily overwhelmed by problems' and 'having trouble concentrating" scored somewhat lower. Apart from 'flushing easily", none of the differences were statistically significant. Given the fact that the 
Table 1. Patient characteristics.

$\mathrm{NO}(n=54) \quad$ FULL $(n=53)$

Gender

Male

$52 \%$

$60 \%$

Age in years

Mean (SD)

$39.9(14.5)$

$15-72$

$34.1(16.5)$

Range

$17-76$

Education

Low level

Medium level

$30 \%$

$31 \%$

$24 \%$

Higher / University level

$7 \%$

$7 \%$

$32 \%$

$42 \%$

Special

$7 \%$

$19 \%$

Unknown

$4 \%$

$4 \%$

Social situation

Living alone

$52 \%$

$38 \%$

Married

$35 \%$

$51 \%$

Living with other person(s)

$6 \%$

$8 \%$

Other

$7 \%$

$3 \%$

Cause of accident

Traffic

$43 \%$

$53 \%$

Nork

$17 \%$

$19 \%$

In or around the house

$13 \%$

$9 \%$

Sports

$13 \%$

$6 \%$

Violence

$9 \%$

$8 \%$

Unknown/Other

$6 \%$

$6 \%$

Reported symptoms on ER

LOC

$80 \%$

$77 \%$

PTA in minutes

mean (SD)

$19(17)$

$19(19)$

Headache

$54 \%$

$70 \%$

Dizziness

$13 \%$

$21 \%$

Nausea

$30 \%$

$25 \%$

Vomiting

$11 \%$

$2 \%$

$\mathrm{LOC}=$ Loss of consciousness.

PTA $=$ Post-tratumatic amnesia . 
Table 2A. Intervention characteristics of the two groups.

\begin{tabular}{llll} 
& NO & FULL & \\
\hline Hours of bed rest & $26(0-26 \%)$ & $57(1-4-102)$ & \\
Mean (min-max) during days $1-10$ & $17(0-72) *$ & & \\
Difficult to comply with advice & $71.0(0-391)$ & $118(0-363)$ & $\mathrm{p}=0.47$ \\
Median (5 and 95 percentiles); & & & Mann-Whitney U \\
Number of oral analgesic tablets & $1(0-24)$ & $3(0-17)$ & $\mathrm{p}=0.47$ \\
Median (5 and 95 percentiles); & & & Mann Whitney U \\
\hline
\end{tabular}

* Two patients with extreme bed rest duration (260 and 158 hours) were excluded.

\# sum day $1-4$.

$\mathrm{NO}=$ no bed rest.

FULL $=6$ days bed rest.

Table 2B. Symptoms during intervention in the two groups.

\begin{tabular}{|c|c|c|c|}
\hline & $\mathrm{NO}$ & FULI & FUi.L versus NO \\
\hline $\begin{array}{l}\text { Symptoms during } \\
\text { intervention }\end{array}$ & $\begin{array}{l}\text { Median } \\
\text { (5 and } 95 \text { percentiles) }\end{array}$ & $\begin{array}{l}\text { Median } \\
\text { (5 and } 95 \text { percentiles) }\end{array}$ & $\operatorname{Exp} B^{*}\left(95 \% \mathrm{Cl}^{5}\right.$ \\
\hline Headache & $93(0-364)$ & $95(0-341)$ & $0.87(0.42-1.80)$ \\
\hline Dizziness" & $49(0-297)$ & $28(0-296)$ & $0.41(0.17-0.848)$ \\
\hline Nausea" & $13(0.296)$ & $14(0-201)$ & $0.78(0.33-1.86)$ \\
\hline
\end{tabular}

* $b=$ Coefficients from linear regression analysis of In outcome variable (symptoms during intervention) on intervention (FULL versus NO bed rest) after adjustment on genclea, social situation and headache, dizziness and vomiting in the ER.

* Sum of visual analogue scales (VAS) for days 1-4.

$\$ 95 \%$ Confidence interval for $\exp B$.

$\mathrm{NO}=$ no bed rest.

FULL $=6$ days bed rest.

medians for 'flushing easily' were zero in both groups, the difference, though statistically significant, was small. After six months, no statistically significant differences in SF-36 scores were found between the two groups, though patients in the FULL group had slightly poorer scores on the bodily pain sub-scale of the SF-36 after adjustment for baseline differences (table 4 and fig 3). 
Table 3. Post-traumatic complaints during follow-up.

\begin{tabular}{|c|c|c|c|c|c|c|}
\hline \multirow[t]{2}{*}{$\begin{array}{l}\text { Post-traumatic } \\
\text { complaints }^{\circ}\end{array}$} & \multicolumn{2}{|c|}{$\begin{array}{l}2 \text { weeks } \\
\text { Median } \\
\text { (5-95 percentiles) }\end{array}$} & \multicolumn{2}{|c|}{$\begin{array}{l}3 \text { months } \\
\text { Median } \\
\text { (5-95 percentiles }\end{array}$} & \multicolumn{2}{|c|}{$\begin{array}{l}6 \text { months } \\
\text { Median } \\
\text { (5-95 percentiles) }\end{array}$} \\
\hline & $\begin{array}{l}\mathrm{NO} \\
(n=51)\end{array}$ & $\begin{array}{l}\text { FULL } \\
(n=52)\end{array}$ & $\begin{array}{l}\text { NO } \\
(n=40)\end{array}$ & $\begin{array}{l}\text { FULL } \\
(n=46)\end{array}$ & $\begin{array}{l}\mathrm{NO} \\
(\mathrm{n}=31)\end{array}$ & $\begin{array}{l}F \cup L L \\
(n=46)\end{array}$ \\
\hline \multicolumn{7}{|l|}{ Cognitive PrC } \\
\hline Trouble concentrating & $6(0-96)$ & $7(0-89)$ & $2(0-84)$ & $2(0-63)$ & $1(0.55)$ & $1(0-85)$ \\
\hline $\begin{array}{l}\text { Easily overwhelmed } \\
\text { by problems }\end{array}$ & $0(0-50)$ & $0(0-10)$ & $0(0-81)$ & $1(0-31)$ & $0(0-46)$ & $1(0-67)$ \\
\hline Forgetful & $7(0-61)$ & $13(21)$ & $4(0-82)$ & $5(0-62)$ & $1(0-30)$ & $4(0-83)$ \\
\hline \multicolumn{7}{|l|}{ Vegetative } \\
\hline Flushing easily & $0(0-21)$ & $0(0-31)$ & $0(0-32)$ & $1(0-40)$ & $0(0-22)$ & $0(0-15)$ \\
\hline Feeling short of breath & $0(0-65)$ & $0(0-50)$ & $0(0-85)$ & $1(0-80)$ & $0(0-37)$ & $1(0-58)$ \\
\hline Feeling raint & $0(0-77)$ & $0(0-29)$ & $0(0-48)$ & $0(0-40)$ & $0(0-18)$ & $1(0-61)$ \\
\hline \multicolumn{7}{|l|}{ Dysthymic } \\
\hline Depressed & $1(0-61)$ & $0(0-49)$ & $(10-88)$ & $2(0-54)$ & $0(0-35)$ & $1(0-62)$ \\
\hline Drowsy & $23(0-91)$ & $8(0-95)$ & $3:(0-85)$ & $2(0-75)$ & $2(0-72)$ & $3(0-91)$ \\
\hline Crying more easily & $0(0-55)$ & $0(0.49)$ & $0(0-88)$ & $1(0-41)$ & $0(0-17)$ & $1(0-42)$ \\
\hline Confused & $1(0-54)$ & $0(0-72)$ & $0(0-79)$ & $1(0-60)$ & $0(0-29)$ & $1(0-71)$ \\
\hline \multicolumn{7}{|l|}{ Physical } \\
\hline Headache & $17(0-100)$ & $9(0.94)$ & $0(0-50)$ & $4(0-69)$ & $4(0-29)$ & $3(0-83)$ \\
\hline Dizziness & $15(0-90)$ & $11(0 \sim 96)$ & $0(0-58)$ & $3(0-77)$ & $1(0-42)$ & $4(0-72)$ \\
\hline Wausea & $0(0-68)$ & $0(0-43)$ & $0(0-26)$ & $1(0-76)$ & $0(0-19)$ & $0(0-57)$ \\
\hline Lightheaded & $3(0-61)$ & $3(0-57)$ & $0 \cdot(0-48)$ & $2(0-49)$ & $1(0-19)$ & $1(0-67)$ \\
\hline Paraesthesia of arm(s) & $0(0-67)$ & $0(0-36)$ & $0(0-46)$ & $1(0-73)$ & $0(0-24)$ & $1(0-68)$ \\
\hline Sleeping problems & $1(0-88)$ & $0(0-80)$ & $0(0-76)$ & $1(0-94)$ & $0(0-57)$ & $1(0-70)$ \\
\hline
\end{tabular}

\# measured on visual analogue scale (VAS).

$\mathrm{NO}=$ no bed rest.

FULL $=6$ days bed rest. 
Table 4. Physical and mental heath during follow-up.

\begin{tabular}{|c|c|c|c|c|c|c|}
\hline \multirow[t]{2}{*}{$S F-36$} & \multicolumn{2}{|c|}{$\begin{array}{l}2 \text { weeks } \\
\text { Mean (SD) }\end{array}$} & \multicolumn{2}{|c|}{$\begin{array}{l}3 \text { months } \\
\text { Mean (SD) }\end{array}$} & \multicolumn{2}{|c|}{$\begin{array}{l}6 \text { months } \\
\text { Mean (SD) }\end{array}$} \\
\hline & $\begin{array}{l}\text { NO } \\
(n=5 \pi\end{array}$ & $\begin{array}{l}\text { FULL } \\
(n=52)\end{array}$ & $\begin{array}{l}\mathrm{NO} \\
(n=40)\end{array}$ & $\begin{array}{l}\text { FULL } \\
(n=4.6)\end{array}$ & $\begin{array}{l}\mathrm{NO} \\
(n=31)\end{array}$ & $\begin{array}{l}\text { FULL } \\
(n=46)\end{array}$ \\
\hline $\begin{array}{l}\text { Physical functioning } \\
\text { Role functioning }\end{array}$ & $76(22)$ & $76(21)$ & $87(17)$ & $90(14)$ & $91(12)$ & $88(15)$ \\
\hline physical & $41(44)$ & $54(45)$ & $60(43)$ & $75(40)$ & $81(35)$ & $77(38)$ \\
\hline emotional & $74(41)$ & $68(42)$ & $72(38)$ & $71(39)$ & $83(32)$ & $80(37)$ \\
\hline Sociall functioning & $65(30)$ & $63(31)$ & $83(21)$ & $84(19)$ & $86(19)$ & $86(21)$ \\
\hline Bodily pain & $53(23)$ & $44(23)$ & $74(23)$ & $78(25)$ & $84(19)$ & $74(27)$ \\
\hline Mental health & $74(19)$ & $71(17)$ & $75(18)$ & $76(18)$ & $76(17)$ & $75(19)$ \\
\hline Vitality & $57(23)$ & $60(23)$ & $65(20)$ & $65(22)$ & $66(18)$ & $68(24)$ \\
\hline General health perception & $75(21)$ & $72(16)$ & $71(21)$ & $72(16)$ & $74(19)$ & $70(20)$ \\
\hline
\end{tabular}

\# Raw scores on the SF-36 were transformed to scaled scores ranging from 0 to 100 , where higher scores reflect better health or less impact on functioning.

$N O=$ no bed rest.

FULL $=6$ days bed rest.

After three months, most PTC in the 'physical' category were given slightly higher scores in the FULL group, whereas cognitive and dysthymic complaints tended to be given slightly lower scores in this group (fig 2). Patients in the FULL group had slightly better scores on almost all SF-36 sub-scales (table 4). Only the difference for physical role functioning was more marked. None of these differences were significantly different after three months.

After two weeks, patients in the FULL group had slightly lower VAS scores than those in the NO group on 14 of the 16 PTC (fog 2). The only significant difference, however, was in 'feeling faint', but since the medians for both groups were zero, the group difference was very snall. 'Forgetfulness' and 'crying more easily' were given higher scores in the FULL group after two weeks. At this same follow-up moment, patients in the FULL group had higher scores on the SF-36 sub-scales of physical role $(\mathrm{p}=0.09)$ and vitality, both measuring physical health (table 4 and fig 3). However, these patients scored slightly lower on emotional role functioning and also had more bodily pain than those in the NO group. Again, none of the differences reached statistical significance. 


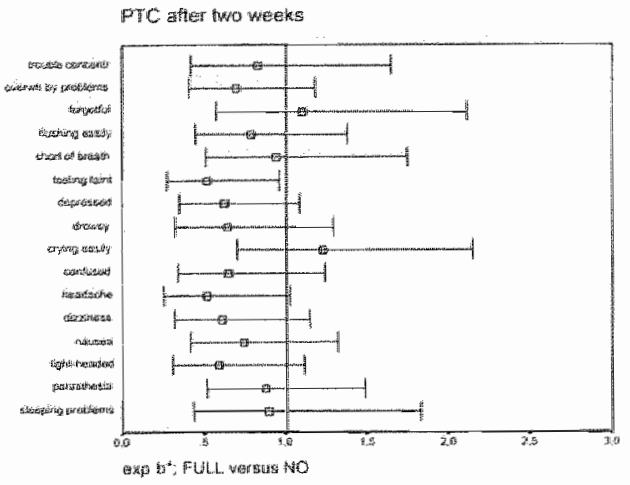

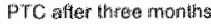

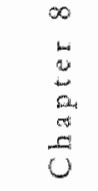

4

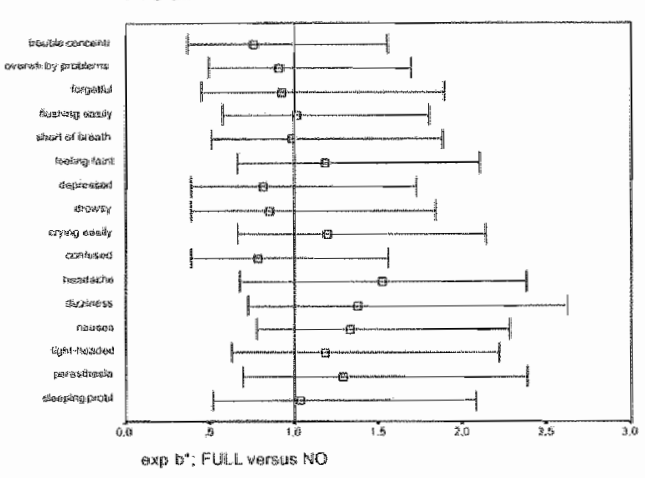

PTC after six rronthe

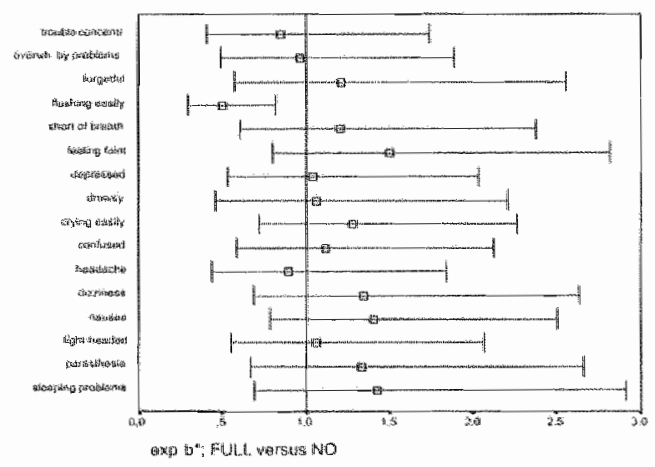

Fig 2. Post-traumatic complaints after 2 weeks, 3 months and 6 months in mild traumatic brain injury patients with and without full bed rest. 


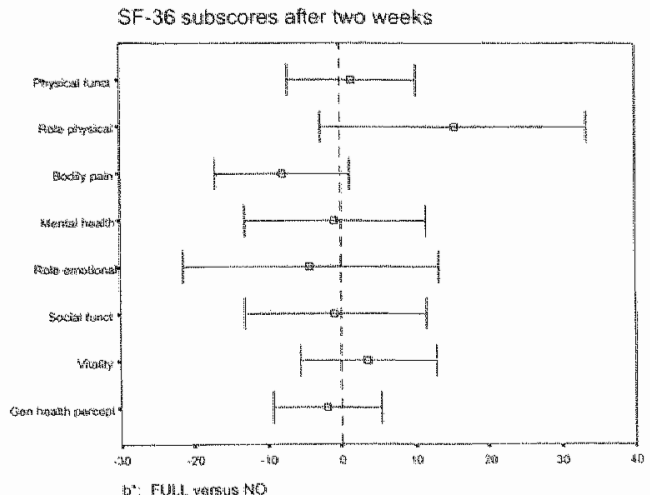

SF-36 subscores atier 3 months

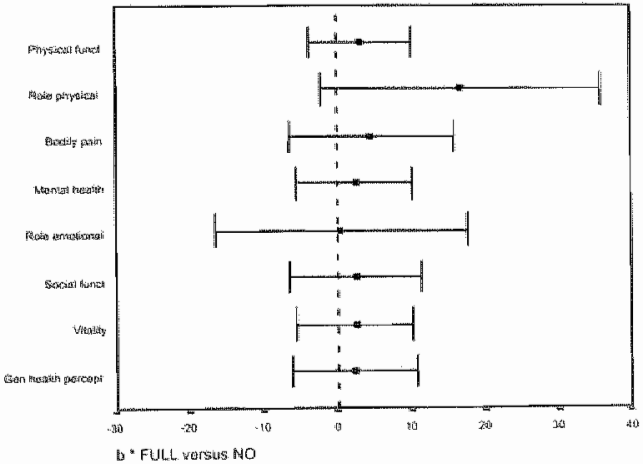

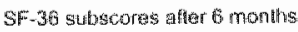

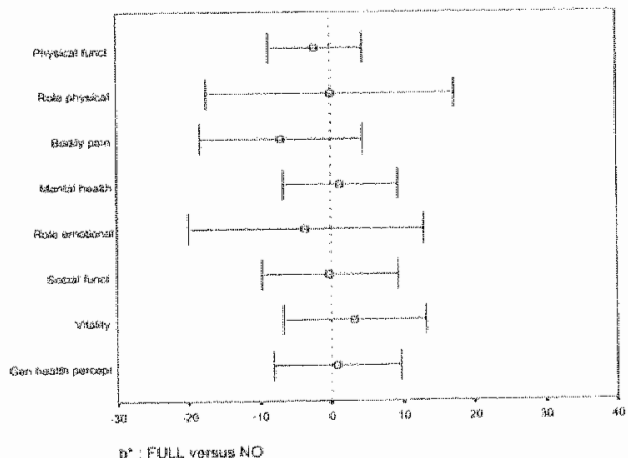

Fig 3. SF.3.6 subwcores after 2 weeks, 3 months and 6 months in mild traumatic brain injury patients with and without 6 days full bed rest. 


\section{DISCUSS10 N}

Principal findings. The results of the present study indicate that the advice to take six days of complete bed rest had no beneficial effect on the severity of PTC or on generic health status at six months after MTBI.

Relation to other studies. Previous studies have addressed both the effectiveness of PTC prevention and the treatment of persistent PTC in patients with MTBI. However, an generally accepted treatment of MTBI patients to prevent PTC has never been established. Educating patients about possible complications shortly after MTBI might help to reduce the severity of PTC later on. $(5,13,15,16)$ Pharmacological treatment seems to have little or no effect on either prevention or treatment of PTC.(17-19,25) The effectiveness of bed rest in patients with MTBI has never before been investigated in a randomised trial, though one study suggested that bed rest lasting more than two weeks after MTBI resulted in poorer outcome than briefer bed rest. (20) Because this was an observational study, no conclusion about causality could be drawn. Indeed, the same association would have been found if greater severity of the trauma led to both longer bẻd rest and more PTC.

In a recent survey in Europe, we found that many neurologists (40\%) recommend full bed rest after MTBI. The recommended period of bed rest ranged from 1-14 days (21) The study concluded that there was no consensus about recommendations for the length of bed rest, the length of the work pause and the need for any follow-up of these patients.

Strengths and weaknesses of the present stwdy. Estimated prevalence and severity of PTC in previous studies have often differed because different definitions of MTBI were used. The MTBI patient population in the present study was clearly defined according to the most recent opinion in literature $(7,26,27)$

In order to evaluate compliance with the prescribed bed rest, we measured the actual duration of bed rest in both groups. Although patients in the NO group rested for too long (a mean of 7 hours too long) and patients in the FULL group rested for less than the recommended number of hours (a mean of 15 hours less), a robust contrast between the intervention groups was obtained.

The number of patients included in our study was lower than expected, given the large number of MTBI patients presenting at our hospital during the inclusion period. Since the rate of non-inclusion was mostly caused by work strain in the 
emergency department, it seems unlikely that the enrolled patients represented a selection of patients for whom bed rest was less or more effective. A latger study would have been more attractive, but in our opinion, the present results support the conclusion that bed rest does not improve outcome at six months after mild traumatic brain injury. The null- hypothesis: "Bed rest after mild traumatic brain injury does not improve outcome at six months" could not be rejected statistically. However, it is very unlikely that a larger sample size would show a favourable effect of bed rest because at 6 months follow up, for most outcome variables there was a trend that favoured the no bed rest group.

The follow-up rates of $87 \%$ (FULL) and $61 \%(\mathrm{NO})$ at six months were similar to those in earlier studies. $(16,28)$ Our evaluation was made at the outpatient clinic, and it proved impossible to achieve complete follow-up in this group of relatively young, working and often fully recovered patients. Although we do not know the reasons why fewer patients showed up in the NO group, we found that most patients who did not show up after six months had no complaints at three months. This finding supports the idea that the absence of PTC was a reason for not showing up for follow-up in the whole group, but that patients in the FULL group may have been more motivated to show up for follow-up due to their more intensive treatment. If this is true, the severity of PTC in both groups was overestimated and this bias would be larger in the NO group than in the FULL group. As a consequence, the negative effect of bed rest at six months should have been even more pronounced.

Implications for MTBI patients. In spite of the fact that our results do not show a clear effect of bed rest on outcome after MTBI, some notable trends became apparent from this study:

First, during the first days following a MTBI, patients who were advised to take full bed rest reported significantly less dizziness than patients who were advised not to take bed rest. However, patients in the full bed rest group found it more difficult to comply with the advice to take bed rest, and used more oral analgesics. Second, almost all post-traumatic complaints after two weeks tended to be less severe in the FULL group, while after six months, there were hardly any differences. It was especially the 'physical' complaints which seemed to be favourably influenced by bed rest in the short term, while this positive effect of bed rest completely disappeared or was even reversed later. 
Third, bed rest also had a slight positive effect on physical health as measured by the SF-36 after two weeks, but this positive effect may have been offset by the increased experience of bodily pain and the slightly worse mental health shortly after the intervention period.

In view of these findings, bed rest probably can palliate dizziness during the first week after the trauma. We do not recommend bed rest to improve outcome after mild traumatic brain injury.

\section{REFERENCES}

1. Kras J, McArthur D, Silveman T, Jayaman M. Epidemiology of Brain Injury. In: Narayan R, Wilberger J, Powlishock J, editors. Neurotrauma. New York: Mc Graw-Hill; 1996. p. 13-30.

2. Thomhill S, Teasdale G, Murray $G$, McEwen J, Roy C, Penny K. Disability in young people and adults one year after head injury: prospective cohort study. BMJ $2000 ; 320(7250): 1631-35$.

3. Meerhoff $S$, Kruijk de J, Rutten J, Lefers P. Twijnstra A. De incidentie van tratumatisch schedel-of hersenletsel in het adherentiegebied van het Academisch Zickenhus Mastricht in 1997. Ned Tijdschr Geneeskd 2000;144(40):915-23.

4. Hase J. Social-economic impact of head injury. Acta Neurochir. 1992;55(supp1):75-79.

5. Injury NCDPoRoPwTB. Relabilitation of persons with Traumatic Brain Injury. JAMA 1999,282(10),974-983.

6. King S. Emotional, neuropsychological, and organic factors: their use in the prediction of persisting postconcussion symptoms after moderate and mild head injuries. J Neurol Neurosurg Psychatry 1996:61:75-81.

7. Alexander M. Mild tratame brain injwy: Pathophysiology, natural history, and dinical managenent. Neurology $1995 ; 45: 1253-1260$.

8. Lewin $H_{*}$ Mattis $S, R u f f$. Eisenberg $H$, Marshall L, Tabaddor $K$, er al. Neurobehavional oucome following minor head injury: a the ecenter study. J Neurosurg 1987,66:234-243.

9. Rutherford W. Postconcussion symptoms: relationship to acute neurological indices, individual differences, and circumstances of injury. In: Mild Head lnjury. New York: Oxford Uniwersily lles: 1989, p. $217-240$.

10. Bohnew $N$, Winnen $G$, Twijnstra $A$, van Zutphen W, Jolles $J$. The constellation of late post - tramatic symptoms of mild head injury patients. I Neurol Rehab 1995;9(1):33-39.

11. Naalt van der J, Zoneren A, Sluter W, Munderhoud $\mathbb{J}$. One year outcome in mild and moderate head injury: the predictive value of acure injury characteristics related to complaints and retum to work. I Neurol Neurosurg Psychiatry 1999;66:207-213. 
12. Paniak C, Phillips K, Toller-Lobe G, Durand A, Nagy I. Sensitivity of three recent questionnaires to Mid Traumatic Brain Injury-Related Effects. I Head Trama Rehabil $1999 ; 14(3): 211-19$.

13. Minderhoud J, Boelens M, Huizinga J, Saan R. Treatment of minor head injuries. Clin Neurol Neurosurg 1980;82:127-140.

14. King $N$, Crawford $S$, Wenden F, Moss N, Wade D. Interventions and service need following mild and moderate head injury: the Oxford Head Iajury Service. Clin Rehab $1997 ; 11: 13-27$.

15. Paniak C. Toller Lobe $G$, Reynolds S, Melnyk A, Nagy J. A randomized trial of two treat ments for mild tramatic brain ingury: 1 year follow-up. Brain Inj 2000; 14(3):219-26.

16. Wade D, King N, Wenden F, Crawford $S$, Caldwel F. Routine follow up atter head ingury: a second randonised trial. I Neurol Neurosurg Psychiary 1998;65:177-183.

17. Bohnen NI, Twijnstra A, yolles J. A controlled trial with vasopressin analogne (DGAVP) on cognitive recovery inmediately after head trauma. Neurology $1993 ; 43(1): 103-6$.

18. Merchant RE, Bullock MR, Carmack CA, Shah AK, Wilner KD, Ko G, et al. A double-blind, placebo-controlled study of the safery, tolerability and pharmacokinetics of $\mathrm{CP}-101,606$ in patients with a mild or moderate tratmatic brain injury. Ann N Y Acad Sci 1999;890:42-50.

19. Chapman EH, Weintrab RJ, Miburn MA, Pirozzi TO, Woo E. Honeopathic treament of mild trammatic brain injury: A randomized, double-blind, placebo-controlled dinical trial. J Head Trama Rehabil 1999;14(6):521-42.

20. 't Hooft van F. Commotio cerebri en andere gevolgen van schedeltramata; ziekteverloop en prognose. Utrecht: Rijksuniversiteit Utrecht; 1973.

21. Kruijk de J. Management of mild tramatic brain ingury: lack of consensus in Europe. Bram $\operatorname{Inj} 2001 ; 15(2): 117-124$

22. Allen C, Glasziou P, Del Mar C. Bed rest: a potential harmful treatment needing more careful evaluation. The Lancet 1999;354(October 9):1229-1233.

23. Aaronson N. Multer M, Cohen P, Essink-Bot M, Fekkes M, Sanderman R, et al. Translation, Validation, and Noming of the Durd Language Version of the $\$ F-36$ Heald Survey in Communiry and Chronic Disease Populations. I Clin Epidemiol $1998 ; 51(1): 1055-1068$.

24. McHomey C, Ware J, Racek A. The MOS 36-item Short-Fom Health Survey (SF-36): If Psychometric and clinical tests of validity in measuring physical and mental health constructs. Medical care 1993;31(3):247-263.

25. Levin $\mathrm{H}$. Treatment of postconcussional symptoms with CDP-chohne. I Neurological Sci $1991 ; 103$ (suppl):s 39-s42.

26. Nell V. Yates DW, Kruger J. An extended Glasgow Coma Scale (CCS-E) with culmanced sensitwity to mild brain injury. Arch Phys Med Redabil 2000;81 (5),614-7.

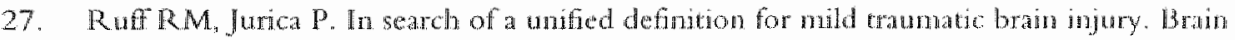
Inj 1999, 13(12):943-52.

28. Pandak $C$, Toller Lobe $G$, Durand $A$, Nagy J. A randomized trial of two tratments for mild traumaric brain injury. Brain Inj 1998;12(12):1011-1023. 
CHAPTER

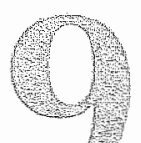

SUMMARY AND CONCLUSIONS 
Although traumatic brain injury is an important catse of morbidity and mortality, most cases are classified as mild traumatic brain injury (MTBI). Ontcome after MTBI is mainly determined by the severity and persistence of post-tratmatic complaints (PTC) like headache, dizziness, poor concentration and depression. Although the severity of most PTC declines during the first three months, their prevalence of PTC six months after the trauma is still appreciable. Predicting the severity of PTC and trying to prevent these complaints is important because they can lead to high costs of health care and to loss of labour productivity work days. Damage to the brain in MTBI patients has been demonstrated by means of elevated serum marker concentrations and abnormalities on Magnetic Resonance Imaging of the brain. However, it is not clear whether PTC are directly caused by brain injury or are rather the result of the trauma experience in combination with psychosomatic, emotional or motivational factors.

In this thesis several studies are presented intending to improve our understanding of the consequences of MTBI for patients.

The first part of the thesis discusses some general topics regarding MTBI. Initially, a literature review of the definitions, diagnostics and treatment used for MTBI was performed. In addition, the frequency of tramatic head and brain injury was estimated by measuring the incidence in a well-defined catchment area in the Netherlands. We also sent questionmaires to neutologists in several European hospitals asking what guidelines they used in their management of MTBI patients.

The second part of the thesis describes follow-up results of a group of MTBI patients from the moment they presented at the emergency room until six months after the tratma. The biochemical serum markers $\mathrm{S}-100 \mathrm{~B}$ and Neuron-Specific Enolase(NSE) in the serum of MTBI patients in the acute situation were measured. Additionally, the olfactory function in MTBI patients after two weeks was aiso measured.

Outcome in MTBI patients. was studied in the course of six months after the trauma. During the first days, MTBI patients often show symptoms like headache, neck pain, nausea, dizziness and vomiting. Like biochemical markers, these acute clinical symptoms could be helpful in assessing the severity of the brain damage. They might also be useful in predicting the occurrence of PTC after MTBI. We assessed the association of serum marker concentrations and the pres- 
ence of acute symptoms at the emergency room with the severity of PTC six months after the MTBI.

Educating MTBI patients shortly after the accident about possible complications might help to reduce the severity of PTC. In order to determine which MTBI patients reguire follow-up at the outpatient clinic, we investigated which combination of acute symptoms and serum markers best predicted the presence of PTC after six months.

Bed rest has been found not to improve the prognosis, and even worsened the outcome in several other medical conditions but the effectiveness of bed rest in preventing PTC has hardly been studied. Still, almost half of the 100 Dutch neurologists surveyed recommended one or more days of bed rest alter MTBI. To assess the usefulness of bed rest, we conducted a randomised trial on the effectiveness of six days of bed rest versus no bed rest on the outcome after six months. Long-term consequences of MTBI for generic health status had not been investigated before. We therefore evaluated its effect on patients' generic health status after two weeks, three months and six months. We also investigated the association between generic health status and the presence of PTC after six months.

In Chapter 1 we reviewed the definitions, differential diagnosis and management of MTBI. We concluded that traumatic brain injury should only be classified as mild if the Glasgow Coma Score (GCS) is optimal (EMV=15) within six hours of admission. Post-traumatic amnesia lasting less than one hour and loss of consciousness lasting less than fifteen minutes are suggested as additional diagnostic criteria. These findings were used in the definition of MTBI in the subsequent studies.

In chapter 2 we measured the incidence of traumatic head and brain injury (THBI) in the catchment area of the University Hospital Maastricht in 1997. The incidence rate of THBI in 1997 was $836 / 100,000$. The frequency of hospital admissions $(88 / 100,000)$ was extremely low. Head injury without brain injury was diagnosed in $75 \%$. The proportion of THBI patients with mild injuries (head injury and/or MTBI) was $99 \%$. This figure was high compared to those reported by other studies. In the sub-group of patients with brain injury, $95 \%$ had MTBI, corresponding to an incidence of $201 / 100,000$. 
In chapter 3 we described the management of MTBI patients in various Eurom pean hospitals. A short questionnaire was sent to neurologists in several European countries. Almost all respondents (94\%) reported that they admitted patients with MTBI to hospital for observation. Forty-one percent of respondents advised patients to take 1 to 14 days of bed rest. Taking sick leave from work was prescribed by 64\%, nanging from 1 to 30 days. At least one follow-up wisit was considered necessary by $70 \%$ of respondents. National guidelines were referred to by $43 \%$ of respondents. At present, according to the results, no consensus about criteria for, or management of MTBT in European hospitals.

In Chapter 4 we measured serum concentrations of Neuron-Specific Enolase (NSE) and S100-B in MTBL patients and controls. Median NSE concentration was only slightly higher in patients $(9.8 \mu \mathrm{g} / \mathrm{l} ; 10$ to 90 percentile range 6.9 to 14.3 $\mu \mathrm{g} / 1)$ than in controls $(9.4 \mu \mathrm{g} / \mathrm{l} ; 6.3$ to $13.3 \mu \mathrm{g} / 1)$. Median $\mathrm{S}-100 \mathrm{~B}$ concentration was significantly higher in patients $(0.25 \mu \mathrm{g} / 1 ; 0.00$ to $0.68 \mu \mathrm{g} / \mathrm{l})$ than in controls $(0.02 \mu \mathrm{g} / \mathrm{l} ; 0.00$ to $0.13 \mu \mathrm{g} / \mathrm{l})$. An association was found between $\mathrm{S}-100 \mathrm{~B}$ concentrations and vomiting in patients. We concluded that $S-100 B$ is a potentially useful marker for brain damage in MTBI.

In Chapter 5 we estimated the prevalence of quantitative olfactory dysfunction after MTBI. Associations of early symptoms and S-100B and NSE serum concentrations with threshold levels of olfactory functions two weeks after MTBI were also examined. The prevalence of olfactory dysfunction two weeks after MTBI was 26\%. No associations were found beween early symptoms, biochemical marker concentrations and olfactory threshold levels. This was surprising because the study reported in chapter 6 demonstrated acute MTBI parameters to be associated with other outcome variables. We concluded that MTBI is associated with post-traumatic olfactory dysfunction, but also that it is important to reproduce our findings and to check the validity of the reference values by including a healchy local control group in future research.

In Chapter 6 we described the severity of PTC in the course of six months after the trama and identified parameters known at first presentation after MTBI which can predict the severity of PTC. After six months, 22 of 79 patients (28\%) reported more severe PTC compared with the pre-tratmatic situation. Head- 
ache, dizziness and/or nausea at the ER was found to be strongly associated with the severity of most PTC after six months. The prevalence of full recovery after six months increased from $50 \%$ in patients with three symptoms to $78 \%$ in those with no symptoms at the ER. Adding biochemical markers showed that all ten patients with no symptoms at the ER and normal markers made a full recovery. We conclude that identifying MTBI patients at the ER without headache, dizziness, nausea and normal serum marker concentrations may be a useful strategy for predicting good outcome.

In Chapter 7 we evaluated the generic health status of MTBI patients in the course of six months after the trauma by means of the 36-item Short-Form. Health Survey Questionnaire (SF-36). Improvements in the sub-scores of physical dimensions were statistically significant between two weeks and three months, while sub-scores of mental dimensions did not change much between these follow-up moments. In contrast, the improvement in the mental sub-score of 'Role-functioning emotional' was statistically significant between three and six months. Although the mean 'General health perception' did not change in the course of six months, all mean SF-36 sub-scores in patients with PTCs were significantly higher than in those without PTC (Mann Whitney U; $<<0.0001$ ). We concluded that most MTBI patients have a nomal generic health status after six months. However, patients with PTC after six months have a clearly impaired generic health status at that moment. In evaluating the outcome after MTBI, the SF-36 Health Survey Questionnaire seems a useful additional test to estimate the influence of MTBI on activities of daily life.

In Chapter 8 we described the results of a clinical trial that evaluated the effect of six days of bed rest on the severity of PTC after MTBI. After adjustment for differences in baseline variables, we found that most PTC rended to be somewhat more severe in the bed rest group six months after the trauma. Two weeks after the tramma, most PTC in the bed rest group were slightly less severe than those in the no bed rest group, while the physical sub-scores on the SF-36 in the bed rest group were slightly better. None of these differences were statistically significant. Patients in the bed rest group reported significantly less severe dizziness during the intervention period. 
Although the study had insufficient power to fully exclude any benefit of treatment, we concluded that it is very unlikely that six days of bed rest is an effective mean of speeding up recovery after MTBI. Bed rest may have some palliative effect within the first two weeks after the trauma.

In conclusion, mild tramatic brain injury is a common traumatic disonder in which signs of brain damage can be demonstrated from early elevated S-100B concentrations and possibly also from olfactory dysfunction. Although the overall outcome is good, about one-fifh of patients have post-traumatic complaints after six months. These complaints are associated with impaired generic health at the same time. The presence of headache, dizziness and/or nausea in the acute situation is predictive of post-traumatic complaints, while early elevated serum markers seem to have additional predictive value. Full bed rest after mild traumatic brain injury is not sufficicnt to improve the outcome after six month.

Future research in $\mathrm{MTBI}$ patients should thoroughly investigate the prediction and treatment of post-traumatic complaints after MTBI. Larger studies will be necessary to obtain precise estimates of combinations of parameters that predict which patients will recover completely. Such predictors should reduce needless follow-up, save money and prevent medicalisation of mainly young and healthy people.

In our opinion, larger studies evaluating the effect of bed rest are not useful. Altemative regular interventions such as 'complaints-driven' mobilisation and taking some time off work may be worth evaluating. Conversely, a strict and active mobilisation schedule or education about post-tamatic conplants could also be the subjects of future research. 
. 


\section{CHAPTER}

SAMENVATTING EN CONCLUSIES 

Hoewel traumatische hersenletsels allerlei klachten en afwijkingen tot gevolg kunnen hebben en zelfs tot de dood kunnen leiden, betreft het meestal lichte traumatische hersenletsels (hersenschudding of commotio). De prognose van een dergelijk licht hersenletsel wordt in belangrijke mate bepaald door het optreden van post-traumatische klachten, zoals hoofdpijn, duizeligheid concentratieproblemen en depressiviteit. De frequentie en de emst neemt gedurende de eerste drie maanden na het ongeval af, echter een deel van de patiënten heeft na zes maanden nog steeds klachten. Het voorkomen en voorspellen van deze klachten is belangrijk, omdat het optreden ervan tot hoge kosten voor de gezondheidszorg en verlies van arbeidsproductiviteit kan leiden.

Het is echter niet duidelijk of de post-traumatische klachten worden veroorzaakt door hersenbeschadiging of door factoren zoals de ongevalervaring, psychologie, emotionele factoren of motivatie.

Beschadiging van de hersenem bij patiënten met licht traumatisch hersenletsel kan worden aangetoond met behulp van afwijkingen op MRI-onderzoek van de hersenen en van markers in het bloed.

In dit proefschrift worden meerdere studies beschreven waabij de gevolgen woor patiënten na een licht traumatisch hersenletsel (LTH) op de voorgrond stan. Het eerste gedeelte van het proefschrift bespreekt enkele algemene aspecten van het lichte traumatische hersenletsel. Allereerst wordt een overzicht gegeven over definities, diagnostiek en verschillende therapieën voor het LTH. Daarna is de incidentie berekend van hoofd en hersenletsel in een duidelijk omschreven verzorgingsgebied in Nederland. Verder werd een enquête uitgèwerkt die de behandeling van LTH door Europese neurologen evalueert.

Het tweede deel van het proefschrift beschrijft de resultaten verkregen bij het vervolgen van patienten met LTH vanaf het moment van het ongeval tot zes maanden daama. De biochemische markers S-100B en Neuron Specific Enolase (NSE) zijn gemeten in bloed dat bimnen zes uur was afgenomen bij dezt patiènten. De gezondheidstoestand van de patiënten is geevalueerd gedurende de eerste zes maanden na het ongeval.

Gedurende de eerste dagen na het ongeval hebben LTH patienten vaak last van hoofdpijn nekpijn, misselijkheid, duizeligheid en braken. Tezamen met biochemische markers zou het aanwezig zijn van deze symptomen gebruikt kunnen worden bij het inschatten van de ernst van de hersenbeschadiging. 
Mogelijk is de aanwezigheid van deze symptomen ook braikbaar voor het voorspellen van de emst van post-traumatische klachien.

Het is aangetoond dat poliklinische controle en voorlichting van LTH patiënten de ernst van de post-traumatische klachten op langere termijn kan verminderen. Om te beoordelen bij welke patiënten een dergelijke voorlichting noodzakelijk is, is de warde van acute serum markers en symptomen voor het voorspellen van de ernst van post-traumatische klachten onderzocht.

Het effect van bedrust op post-traumtische klachten is nooit onderzocht. Hoewel aangetoond is dat bedrust de prognose van verschillende medische condities niet verbetert en soms zelfs verslechtert, schrijft in Nederland bijna de helft van 100 ondervraagde neurologen bedrust van een of meerdere dagen voor na een LTH. Om de warde van bedrust na een LTH te beoordelen, hebben wij een gerandomiseerd onderzoek uitgevoerd waarbij het effect van geen bedrust versus het effect van zes dagen bedrust op de ernst van post-traumatische klachten na zes maanden is onderzocht.

Daanaast hebben we ook de gevolgen van het LTH voor de algemene

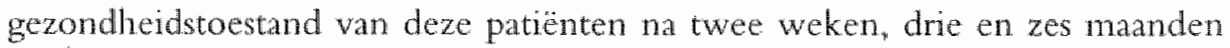
geèvalueerd. Deze gegevens zijn eveneens als uitkomst parameter in de bedrust trial gebruikt.

In hoofdstuk 1 is een overzicht gegeven van de definities, differentiaaldiagnose en behandeling van LTH. We concludeerden dat traumatisch hersenletsel alleen als "licht" gedefinieerd mag worden als de score op Glasgow Coma Schal (GCS) binnen 6 uur na het ongeval optimaal (EMV $=15)$ is. Een post-traumatische annesie van minder dan 6 uur en/of bewusteloosheid van minder dan 15 minuten kunnen worden gebruikt als anvullende diagnostische criteria. Deze bevindingen hebben wij toegepast bij onze definiëring van LTH in het verdere onderzoek.

In hoofdstuk 2 is de incidentie van traumatisch schedel/ hersenlersel in het verzorgingsgebied van het academisch ziekenhuis Mastricht in 1997 berekend. Deze incidentie bedroeg 836 per 100.000 inwoners. De frequentie van ziekenhuisopnamen onder deze patiënten was erg laag $(88 / 100.000)$ in vergelijking met andere landen. In $99 \%$ betrof het een relatief licht letsel (hoofdletsel en/of LTH) en in $75 \%$ een hoofdletsel zonder hersenletsel. Van de 
patiënten met hersenletsel had $95 \%$ een LTH hetgeen overeenkomt met een incidentie van 201 LTH patiënten per 100.000 inwoners per jaar.

In hoofdstuk 3 is onderzoek nar de behandeling van LTH patienten in verschillende Europese ziekenhuizen verticht. Er werd een korte vragenlijst gestuurd maar neurologen in verschillende landen. Bijna alle responders (94\%) hebben geantwoord dat zij patienten met een LTH opnemen in het ziekenhuis voor een korte observatie. Eenenveertig neurologen adviseerden de patienten om 1 tot 14 dagen bedrust te nemen. Door 64\% werd geadviseerd het werk neer te leggen voor de duur van 1 tot 30 dagen. Door $70 \%$ van de neurologen werd tenminste een poliklinische controle na het ongeval noodzakelijk geacht. Het bestan van landelijke richtijnen voor de behandeling van LTH patienten werd door minder dan de helf van de ondervaagden genoemd. Naat aanleiding van deze resultaten concluderen wij dat er geen consensus bestat in Europese ziekenhuizen over de behandeling van LTH patiènten.

In hoofdstuk 4 hebben we de serum concentracies van NSE and S-100B bij LTH parienten met de concentraties van gezonde mensen vergeleken. De mediane NSE concentratie bij de patienten was wat hoger $(9,8 \mu \mathrm{g} / \mathrm{l} ; 10$ tot 90 percentiel 6,9 tot $14,3 \mu \mathrm{g} / \mathrm{l})$ dan bij de gezonde patiënten $(9,4 \mu \mathrm{g} / 1 ; 6,3$ tot 13,3 $\mu g / 1)$. Mediane $S-100 B$ concentraties van patiënten waren significant hoger $(0,25$ $\mu \mathrm{g} / 1 ; 0,00-0,68 \mu \mathrm{g} / \mathrm{l})$ dan van controle persomen $(0,02 \mu \mathrm{g} / 1 ; 0,00$ tot $0,13 \mu \mathrm{g} / \mathrm{l})$. Er is bij LTH patiënten een relatie gevonden tussen verhoogde $\mathrm{S}-100 \mathrm{~B}$ concentraties an het symptoom braken wak na het ongeval. We concluderen dat S-100B mogelijk een marker is voor het antonen van hersenbeschadiging bij LTH patiënten.

In hoofdstuk 5 hebben we het voorkomen van kwantitatieve reukstoomisten na een LTH onderzocht. De relatie tussen de anwezigheid van vroege LTH kenmerken (symptomen en serum markers) en de geurdrempel twee weken ma het ongeval zijn ook bestudeerd. De prevalentie van een gestoorde reukzin bij LTH was twee weken na het ongeval $26 \%$. Er werden geen relaties gevonden cussen vroege latselkenmerken en verhoogde geurdrempels. Deze bevinding is opmerkelijk, omdat de resultaten in hoofdstuk 6 antonen dat andere vroege letselkenmerken wel associèren met uikomstparameters na zes manden. LTH 
kan mogelijk leiden tot een gestoord reukvermogen. Bij vervolgonderzoek zal aen controlegroep moeten worden onderzocht.

In hoofdstuk 6 hebben we de ernst van post-traumatische klachten in het verloop wan de eerste zes maanden na het ongeval onderzocht. Vervolgens hebben we parameters onderzocht die aansluitend aan het ongeval aanwezig waren, en mogelijk de ernst van post-traumatische klachten kumnen voorspellen. Zes maanden na het ongeval rapporteerden 22 van de 79 patiënten (28\%) post-traumatische klachten. De aanwezigheid van hoofdpijn, duizeligheid en/ of misselijkheid direct aansluitend an het ongeval was sterk geassocieerd met de ernst van post-traumatische klachten na zes maanden. De kans op volledig herstel na zes maanden nam toe van $50 \%$ bij patiënten met drie symptomen tot $78 \%$ bij patiënten zonder symptomen direct na het ongeval. Alle patiënten met normale serum markers en zonder symptomen aansluitend aan het ongeval bleken na zes maanden volledig hersteld. We concluderen dat het identificeren van LTH patiënten zonder hoofdpijn, duizeligheid en misselijkheid op de eerste hulp een bruikbare strategie kan zijn bij het voorspellen van een goede prognose.

In hoofdstuk 7 hebben we de algemene gezondheidstoestand van LTH patiënten gedurende de eerste zes maanden na het ongeval geëvalueerd met behulp van de SF-36 vragenlijst. De verbetering van de fysieke subscores op de SF-36 waren significant tussen twee weken en drie maanden terwijl de mentale subscores amper verbeterden in deze periode. Daartegen was de verbetering van de nentale subscore "functionering emotionele rol" significant tussen de derde en zesde maand. Hoewel de gezondheid in $z$ 'n algemeen gedurende de eerste zes manden gemiddeld niet als verslechterd werd ervaren, waren alle SF-36 subscores slechter bij patiënten met post-traumatische symptomen na zes maanden. We concluderen dat de meeste patiënten zes maanden na een LTH een nomale algemene gezondheidstoestand hebben, maar dat de algemene gezondheidstoestand bij patiënten met post-traumatische klachten aanzienlijk slechter is. De SF-36 vragenlijst lijkt een bruikbaar instrument bij het meten van de invloed van een LTH op het dagelijks leven van de patiënten in de eerste zes maanden na het ongeval. 
In hoofdstuk 8 werden de resultaten beschreven van een klinische trial waarbij LTH patiënten aansluitend aan het ongeval gerandomiseerd werd geadviseerd geen bedrust te nemen tegenover zes dagen volledige bedrust. We vonden dat post-traumatische klachten na zes maanden, in de groep die bedrust kreegr geadviseerd, ernstiger leken dan in de groep die dit advies niet kreeg. Twee weken na het ongeval leken de post-traumatische klachten in de bedrust groep wat minder te zijn. Beide verschillen waren niet significant. Patienten in de bedrust groep rapporteerden minder duizeligheid tijdens de interventie.

Hoewel deze studie statistisch niet genoeg "power" had om een gering voordeel van de bedrust interventie uit te sluiten, concluderen wij dat het heel onwaarschijnlijk is dat zes dagen bedrust na een LTH het herstel na zes maanden in positieve zin beinvloedt. Mogelijk heeft bedrust een tijdelijk positief effect tijdens de eerste twee weken na het ongeval.

Samenvattend is LTH een veel voorkomende aandoening, waarbij hersenbeschadiging aangetoond kan worden met behulp van vroeg verhoogde S-100B concentraties in serum. Ook een post-traumatische reukstoornis zou hiermee in verband kunnen worden gebracht.

Hoewel de prognose over het algemeen goed is, heeft ongeveer een kwart van de patiënten met een LTH na zes maanden nog post-traumatische klachten. Deze klachten zijn geassocieerd met een slechtere algemene gezondheidstoestand op dat moment.

De aanwezigheid van hoofdpijn, duizeligheid en/of misselijkheid direct na het ongeval is voorspellend voor de ernst van post-traumatische klachten warbij serum markers mogelijk nog een aanvullende waarde kunnen hebben.

Volledige bedrust direct na het ongeval is niet zinvol ter verbetering van de prognose van een LTH.

Toekomstig onderzoek bij patiënten met LTH is nodig voor het voorspellen en behandelen van post-traumatische klachten na een LTH. Grotere studies zijn nodig om de juiste combinaties van voorspellende parameters voor het wel of niet ontstan van post-traumatische klachten te bepalen. Dergelijke voorspellende parameters kunnen overbodige follow-up na een LTH beperken, medicalisering van jonge gezonde mensen voorkomen en tevens geld besparen. 
Nieuwe studies naar het effect van bedrust op post-traumatische klachten lijken overbodig. Het nut van andere gebruikelijke interventies zoals "klachtgerelateerde" mobilisatic en onderbreking van het werk verdient verder onderzoek. Daarnaast zou ook het effect van minder gebruikelijke interventies zoals een strikt en actief mobilisatieschema of het geven van voorlichting over mogelijke post-tramatische klachten onderwerp van onderzoek kunnen zijn. 


\section{PUBLICATIONS}

1. Hofman P, Stapert S, van Kroonenburgh M, Jolles J, de Kruijk J, Wilmink J. MR Imaging, Single-photon Emission CT, and Neurocognitive Performance after Mild Trammatic Brain Injury. Am I Neuroradiol 2001; $22: 441-449$.

2. Kruijk de J, Leffers $P$, Menheere P, Meerhoff S, Twinstra A. S-100B and neuron-specific enolase in serum of mild traumatic brain injury patients; $A$ comparison with healthy controls. Acta Neurol Scand 2001;103(3):175-179.

3. Kruijk de J. Leffers P, 'Twijnstita A. Diagnostic criteria and differential diagnosis of mild traumatic brain injury. Brain Inj 2001;15(2):99-107.

4. Kruijk de J. Leffers P, Meerhoff S, 'Twijnstra A. Management of mild traumatic brain injury: lack of consensus in Europe. Brain Inj 2001;15(2):117-124.

5. Meerhoff S, Kruijk de J, Rutten J, Leffers P, Twijnstra A. De incidentie van traumatisch schedel of hersenletsel in het adherentiegebied van het Academisch Ziekenhuis Maastricht in 1997. Ned Tijdschr Goneeskd $2000 ; 1.44(40): 915-23$.

6. Kruijk de J, Korten A, Boiten J, Wilmink J. Acute cauda equina syndrome caused by thrombosis of the inferior vena cava. I Neurol Neurosumg Psychiatry 1999,67:827-28.

7. Stokroos R, Manni J, Kruijk de J, Soudijn E. Lemierre Syndrome and acute Mastoiditis. Arch Otolaryngol Head Neck Surg 1999;125:589-91. 
8. Priester de J, Jansen G, Kruijk de J. Wilmink J. New MRI findings in Creutzfeldt-Jakob disease: high signal in the globus pallidus on $\mathrm{T} 1$-weighted images. Neuroradiology 1999;(41):265-268.

9. Oostenbrugge van $\mathrm{R}$, Herpers $M$, Kruijk de J. Spinal cord compression caused by unusual location and extension of ossified ligamenta flava in a caucasian male; acase report and literature review. Spine 1999;24(5):486-88.

10. Smeenk B, Boiten J, Verheggen F, Kruijk de J, Wilmink J, Kessels F. Effect van invoering van protocol 'Indicatiestelling voor cervicaal röntgenonderzoek bij hoofd en/of nektrauma'. Kwaliteit en zorg 1998;2:71-77.

11. Kruijk de J, Twijnstra A, Leffers P. Geen uniformiteit in radiodiagnostiek en adviezen van Nederlandse neurologen bij patiënten met licht hersenletsel. Ned Tijdschr Geneeskd 1996;140(35):1763-1765.

12. Kruijk de J, Twijnstra A, Leffers P, Wilmink J. Röntgendiagnostiek bij hoofd- en/of nektrauma. Wanneer zijn röntgenfoto's van de cervicale wervelkolom geündiceerd? Ned Tijdschr Traum 1994;5:119-126. 


\section{DANKWOORD}

Naast de anonieme patiënten die meededen aan dit onderzoek wil ik verschillende mensen in mijn omgeving bij naam noemen en bedanken voor hun steun gedurende de jaren waarin dit proefschrift tot stand kwam.

Geachte Professor Troost, beste Jaap. Vanuit de collegebanken kreeg ik de gelegenheid de basis voor dit proefschrift te leggen. Vrijwel direct anansluitend begon ook mijn klinische opleiding. Beide sporen heb ik zo goed mogelijk geprobeerd te combineren. Soms gaf mij dat het gevoel van een onmogelijke spagaat, maar jouw vertrouwen in een goede afloop heeft angetoond dat zelfs een tweesporen beleid tot resultaten kan leiden.

Dr. A Twijnstra, beste Albert, als student gaf je me al de gelegenheid on te proeven aan de wetenschap. Je stimuleerde me om in andere keukens te kijken, maar legde uiteindelijk de basis voor het recept van dit Maastrichtse proefschrift. Bedankt voor je begeleiding en stimulans gedurende het gehele onderzoekstraject. Je rol als copromotor in het laatste jaar van mijn opleiding is de kroon op onze wetenschappelijke en klinische samenwerking.

Drs. Ir. P. Leffers, beste Pieter, als epidemioloog heeft je begeleiding zich niet beperkt tot het bewaken van de methodologie alleen. Achter de schermen, maar ook tijdens het overleg, was je inbreng essentieel. Sinds afgelopen jaar associcer ik Koninginnedag niet meer met koekhappen op een drukke Amsterdanse rommelmarkt maar met mooie lineaire regressies in een rustige Maastrichtse stadstuin. Je afwezigheid op "het podium" ervar ik als een gemis.

Dr. P. Menheere, beste Paul, bij de opzet van het onderzoek was er slechts cen pilot-plaats voor het klinisch chemisch onderzoek. Uiteindelijk was je bijdrage echter zo belangrijk dat er, voorafgaande an de promotie, een minisymposium aan gewijd kan worden. Bedankt woor de samenwerking.

Drs. S. Meerhoff en Drs. J. Rutten, Saskia en Joost, als student-assistenten waren jullie onmisbaar; als fijne collega-onderzoekers trouwens ook. Saskia, jij legde de letterlijke (data) basis voor het onderzoek en bent als paranimf nauw betrokken bij de finale. Joost, jij was de onzichtbare logistieke motor tijdens de follow-up. 
Bedankt, en hoewel jullie je eigen weg alweer vervolgd hebben, zullen onze paden ongetwijfeld weer kruisen.

Drs. S. Stapert; beste Sven, samen hoopten we op meer patiénten voor onze onderzoekslijnen. Bedankt voor je vasthoudend meedenken en succes met de afronding van je eigen promotieonderzoek.

Neurologen en collega (oud)assistenten, hoewel ik me wel eens mopperend uitliet over de achterblijvende inclusiecijfers, is het uiteindelijk mede aan jullie te danken dat ik de data voor dit proefschrift heb kunnen verzamelen en bewerken. Velen van jullie beschouw ik intussen als vrienden warmee ik hopelijk nog mooie dingen in het verschiet heb, zowel tijdens als naast het werk.

Peter, net zoals ik nog steeds niet weet of je me af en toe liet winnen met schaken, weet ik ook niet of ik je als paranimf beloon of juist straf. In ieder geval alvast bedankt voor je back-up.

Alle medewerkers van de afdeling spoedeisende hulp, polikliniek neurologie en secretariaat neurologie in ons ziekenhuis, bedankt voor jullie hulp en medewerking aan het onderzoek.

Marjolein en Marjon, bedankt voor de lage inloopdrempel. In de rol van déskundige en vertrouwde buren toetsten jullie als eerste buitenstaanders het concept van dit boekje.

Vrienden van Plutarchus, het afronden van dit proefschrift is een gebeurtenis die mede gebaseerd is op inspiratie die wij door de jaren heen deelden en altijd zullen delen.

Lieve pap en mam, bedankt voor het warme nest, het vertrouwen en de stimulans, toen en nu. Jullie hebben me geleerd dat de lat soms iets hoger kan zonder daarbij mijn nek te breken. Peter, Simone en Daan, alweet vijftien jaar geleden verdwalde ik in de Limburgse heuvels en bleef er zelfs hangen. Voorlopig verzuim ik mijn taak als oudste broer; bedankt dat jullie aan de Hollindse kust een oogje in het zeil hielden.

Eva, je bent mijn kleine ster; jouw vrolijkheid en aanpassingsvermogen kregen we cadeau en geven me het vertrouwen dat je broertje of zusje ons leven nu nog mooier kleurt.

Bedanke liefste Annick, met jou samen is geen zee te hoog. Jij moest in de rol van partner, collega en moeder vaak alle zeilen bijzetten maar was altijd naast me. Ik verheug me op alles wat nog voor onze boeg ligt. 